Universidade Estadual Paulista Júlio de Mesquita Filho. Faculdade de Ciências Farmacêuticas.

Campus de Araraquara.

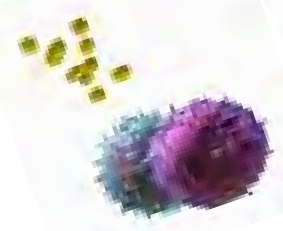

\title{
Atividade Anti - Tumoral e Imunomodulatória de Complexos de Paládio (II) Utilizando Modelo Experimental de Ehrlich
}

Marcela Bassi Quilles

Orientadora: Iracilda Zeppone Carlos

\section{Araraquara-SP}

2010 
Universidade Estadual Paulista Júlio de Mesquita Filho.

Faculdade de Ciências Farmacêuticas.

Campus de Araraquara.

\section{Atividade Anti - Tumoral e Imunomodulatória de Complexos de Paládio (II) Utilizando Modelo Experimental de Ehrlich}

Marcela Bassi Quilles

Dissertação apresentada ao Programa em Biociências e Biotecnologia Aplica á Farmácia (área de Imunologia), da Faculdade de Ciências Farmacêuticas da Universidade Estadual Paulista, como requisito parcial para obtenção do título de Mestre.

Orientadora: Iracilda Zeppone Carlos

Araraquara-SP

2010 
Este trabalho foi desenvolvido no Laboratório de Imunologia Clínica do Departamento de Análises Clínicas da Faculdade de Ciências Farmacêuticas da Universidade Estadual Paulista (UNESP) de Araraquara com auxilío de bolsa CAPES (Coordenação de Aperfeiçoamento de Pessoal de Nível Superior). 


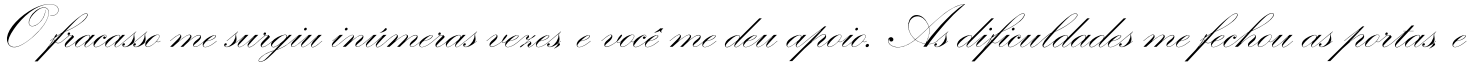

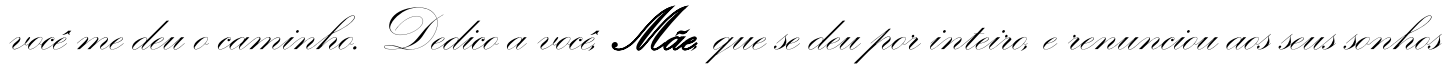

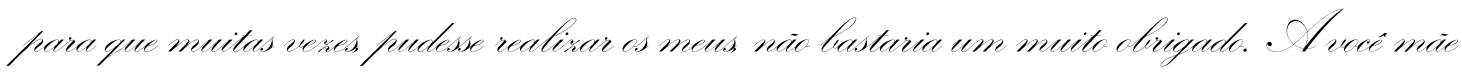

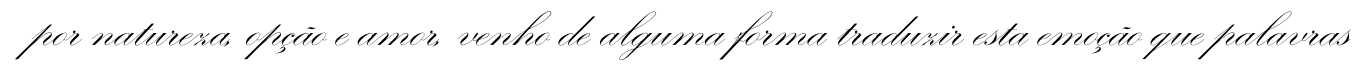

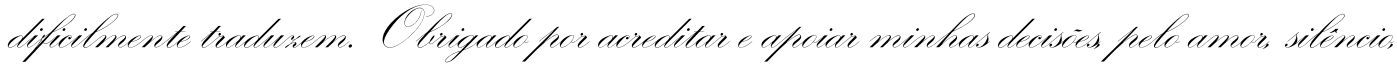
compricensio oferecidos. - Amo vocé.... 


\section{Hgradecimentos}


- Deus que desde a inicio dessa caminhada. Fu estarras presente. Ditorias foram conquistadas. Qovolas foram sufecradas. Ominades foram criadas. Conhecimentos foram adyuiridos. ....e agora que alcancei meu dijetivo, ventio the aquadecer humildemente a vitória desse momento. Obigada Senhor.

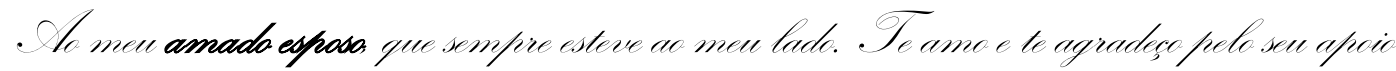

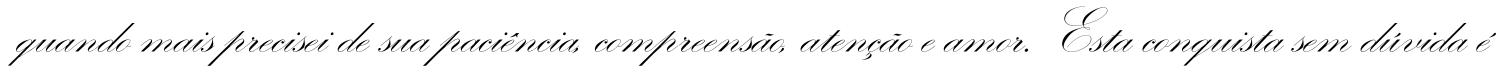
sua tambiom. Obrigada for undorl!!

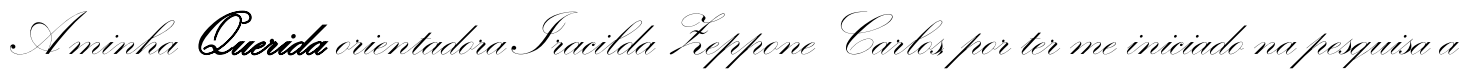

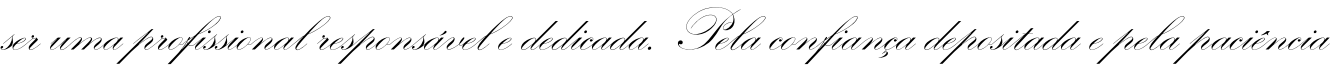
disferensada.

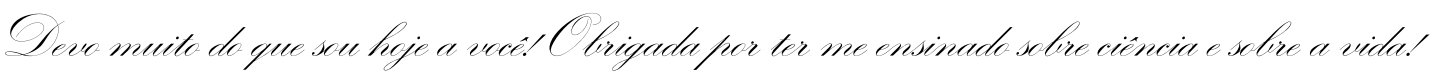

- Hos colegas de vabatho que fineram os momentes dificeis mais aguadaveis com fallaviras de conforto e animo, o for loda ajuda feara tormino deste babalho.

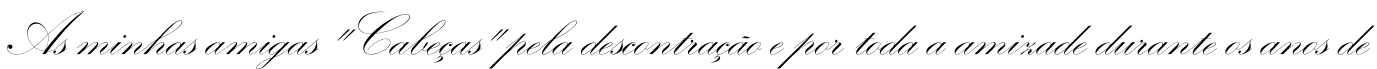
convivência, ncio sei o que sevia sem vocês!

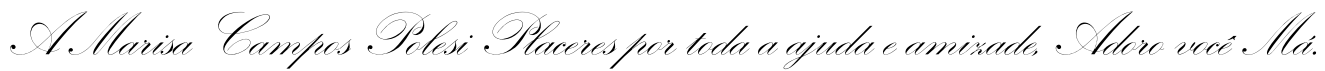

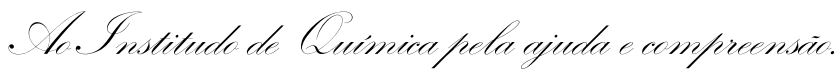




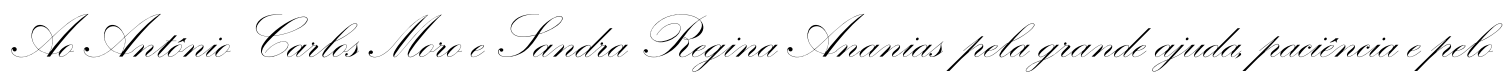
fornccimento dos matoriais dos compostos estudados.

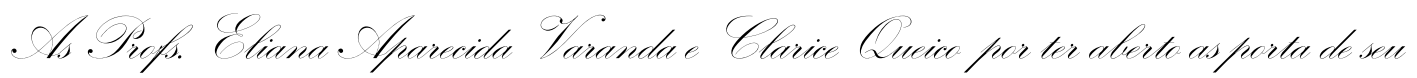

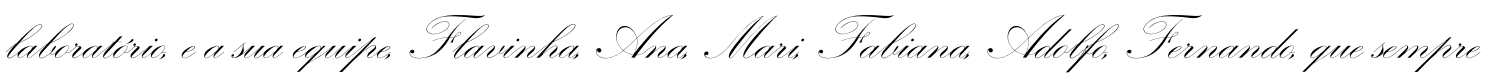
estiveram solicitos a ajuedar, muita obrigada.

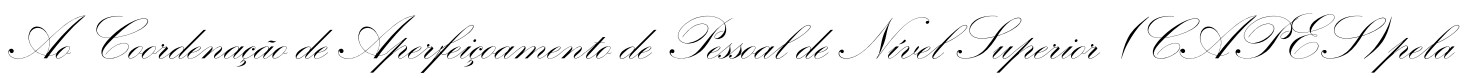
boba concedida. 


\section{RESUMO}

O câncer, manifestação originada pelo crescimento descontrolado de células, afeta milhões de indivíduos. Os macrófagos são as primeiras células a serem ativadas para participar de uma resposta imunológica propriamente dita, são células capazes de secretar mais de cem produtos biologicamente ativos, entre esses, espécies reativas de nitrogênio e citocinas que atuam no contexto da resposta imunológica e/ou inflamatória. Sabendo que compostos de paládio (II) podem apresentar potenciais atividades anti tumorais, neste trabalho foram testado os compostos de fórmula geral $[\mathrm{Pd}(\mathrm{dmba})(\mathrm{Cl}) \mathrm{tu}]$ e $\left[\operatorname{Pd}(\mathrm{dmba})\left(\mathrm{N}_{3}\right) \mathrm{tu}\right]$, nos quais dmba $=\mathrm{N}, \mathrm{N}$-dimetilbenzilamina e tu = tiouréia quanto a atividade antiinflamatória, antitumoral e mutagênica dos mesmos.Como droga padrão das reações realizadas foi utilizada a cis-platina. Foi determinada a ação destes compostos frente ao sistema imunológico através, de ensaios de determinação de citotoxicidade mediano $\left(\mathrm{IC}_{50}\right)$ pela técnica de MTT, óxido nítrico $(\mathrm{NO})$, peróxido de hidrogênio (H2O2), determinação das citocinas IL-1, IL-6, IL-12, TNF- $\alpha$ e IL-10. Além disso, foi determinado a atividade antitumoral dos compostos frente à célula tumoral de Ehrlich, assim como a atividade mutagênica pelo teste de Ames e Ensaio com plasmídio pUC 9.1. Os resultados mostraram produção de NO e das citocinas IL-1, IL-6, IL-12 e TNF- $\alpha$; moderada produção de $\mathrm{H}_{2} \mathrm{O}_{2}$ pelos macrófagos peritoneais de animais normais e animais portadores do tumor de Ehrlich na sua forma sólida, estimulados com os compostos e seus ligantes, assim como a cis-platina. Por outro lado, de maneira contrária às outras citocinas testadas, não houve a produção de IL-10. No que se refere à atividade antitumoral dos compostos testados, estes mostraram efeito citotóxico sobre a linhagen tumoral testada. Com relação à atividade mutagênica, os compostos e ligantes não foram mutagênicos in vitro, diferente da cis-platina que demontrou-se mutagênica, ocasionando mutações pontuais no DNA de Salmonella typhimurium, pelo teste de Ames. Os compostos e ligantes também não foram capazes de induzir quebras no DNA pelo ensaio com plasmídio pUC 9.1. Levando em consideração a não mutagenicidade dos compostos e de seus ligantes, assim como a capacidade dos mesmos de estimularem a produção de citocinas pró-inflamatórias em animais portadores do tumor de Ehlich, estes demonstram-se promissores uma vez que mesmo sendo capaz de estimular o sistema imune não provoca toxicidade e mutagenicidade ao DNA.

Palavras-chaves: Macrófagos, Interleucinas, Óxido nítrico, Tumor de Erlich, Organometálicos e Mutagenicidade. 


\begin{abstract}
The cancer, manifestation originated by the growth not controlled of cells, affects million of individuals. Macrophages are the first cells to be activated to participate in an immune response itself, are cells to able to secreting more than one hundred biologically active products, among these, reactive nitrogen species and cytokines that act in the context of the immune response and / or inflammatory. Knowing that compounds of palladium (II) can be potential activities anti - tumor in this study was tested compounds of general formula $\left[\mathrm{Pd}(\mathrm{Pd})(\mathrm{Cl})\right.$ tu] and $\left[\mathrm{Pd}(\mathrm{Pd})\left(\mathrm{N}_{3}\right)\right.$ tu $]$, where $\mathrm{Pd}=\mathrm{N}, \mathrm{N}$ dimetilbenzilamina and $\mathrm{tu}=$ thiourea as the anti-inflammatory, antitumor and mutagenic of the same. As standard was used the cis-platinum. We determining the action of these compounds against the immune system, for tests to determine the median cytotoxicity $\left(\mathrm{IC}_{50}\right)$ by the MTT technique, nitric oxide (NO), hydrogen peroxide $\left(\mathrm{H}_{2} \mathrm{O}_{2}\right)$, determination of IL-1, IL-6 , IL-12, TNF- $\alpha$ and IL-10. Moreover, it was determined the antitumor activity of compounds against the Ehrlich tumor cell, as well as mutagenic by the Ames test and test with plasmid pUC 9.1. The results showed NO production and the IL-1, IL-6, IL-12 and TNF- $\alpha$, by peritoneal macrophages from normal animals and animals with Ehrlich tumor in solid form was stimulated by the compounds and their ligands as well as cis-platinum. Moreover, in contrary manner to other cytokines tested, there wasn't production of IL-10, and $\mathrm{H}_{2} \mathrm{O}_{2}$. With regard to the antitumor activity of the compounds tested, these showed cytotoxic effect on tumor lineage tested. With respect to mutagenic activity, compounds and ligands weren't mutagenic in vitro, unlike cisplatinum was shown to be mutagenic, causing mutations in the DNA of Salmonella typhimurium by the Ames test. The compounds and ligants were not also to induce DNA breaks in the plasmid pUC 9.1 test. Taking into account the non-mutagenicity of compounds and their ligands, as well as of their capacity to stimulate the production of proinflammatory cytokines in animals with tumor Ehrlich, they show themselves to be promising when compared with cis-Pt, as that even being able to stimulate the immune system no causes toxicity and mutagenicity in DNA.
\end{abstract}

Keywords: Macrophages, Interleukins, nitric oxide, tumor Erlich, Organometallic and Mutagenicity. 


\section{LISTA DE FIGURAS}

Figura 1: Representação esquemática da formação do anel ciclometalado .25

Figura 2: Placas com Salmonella typhimurium (Teste de Ames). .34

Figura 3: Produção de peróxido de hidrogênio em culturas de células peritoneais aderentes .56

Figura 4: Produção de óxido nítrico em culturas de células peritoneais aderentes .58

Figura 5: Produção de TNF- $\alpha$ nos sobrenadantes das culturas de células aderentes .60

Figura 6: Produção de interleucina-1 $\beta$ nos sobrenadantes das culturas de células aderentes .62

Figura 7: Produção de IL-6 nos sobrenadantes das culturas de células aderentes. 64

Figura 8: Produção de IL-12 nos sobrenadantes das culturas de células aderentes. .66

Figura 9: Produção de IL-10 nos sobrenadantes das culturas de células aderentes .68

Figura 10: Eletroforese em gel de agarose a $0,8 \%$ e análise densitométrica das concentrações das conformações superhelicoidizada (SH), circular aberta (CA) e linear (L) do plasmídeo pUC9.1, após tratamento com o composto $1[\mathrm{Pd}(\mathrm{dmba})(\mathrm{Cl}) \mathrm{tu}]$ .75

Figura 11: Eletroforese em gel de agarose a 0,8\% e análise densitométrica das concentrações das conformações superhelicoidizada (SH), circular aberta (CA) e linear 
(L) do plasmídeo pUC9.1, após tratamento com 0 composto 2

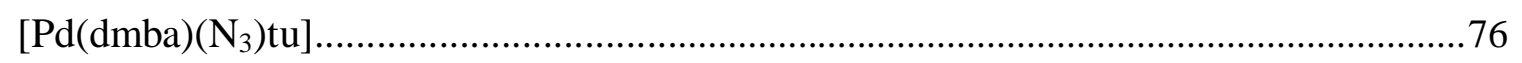

Figura 12: Eletroforese em gel de agarose a 0,8\% e análise densitométrica das concentrações das conformações superhelicoidizada (SH), circular aberta (CA) e linear (L) do plasmídeo pUC9.1, após tratamento com o ligante dmba. .77

Figura 13: Eletroforese em gel de agarose a $0,8 \%$ e análise densitométrica das concentrações das conformações superhelicoidizada (SH), circular aberta (CA) e linear (L) do plasmídeo pUC9.1, após tratamento com o ligante

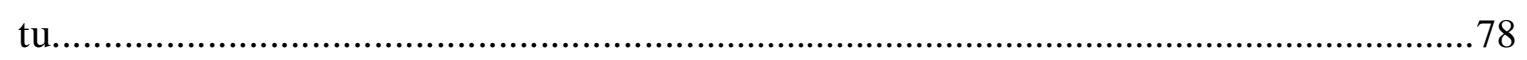

Figura 14: Eletroforese em gel de agarose a $0,8 \%$ e análise densitométrica das concentrações das conformações superhelicoidizada (SH), circular aberta (CA) e linear (L) do plasmídeo pUC9.1, após tratamento com o ligante cisplatina. 


\section{LISTA DE TABELAS}

Tabela 1 : Valores de $\mathrm{IC}_{50}$ dos compostos para as células aderentes peritoneais de camundongos normais e portadores do tumor sólido de Ehrlich após 24 de exposição...

Tabela 2 : Valores de $\mathrm{IC}_{50}$ dos compostos para as células tumoral de Erlich após 24 de exposição.

Tabela 3 : Atividade mutagênica expressa pela média do número de revertentes, desvio padrão e razão de mutagenicidade (valor entre parênteses) na linhagen, TA102 de $S$. typhimurium expostas a várias doses dos compostos e cis-platina, com (+S9) ou sem (S9) ativação metabólica.

Tabela 4 : Atividade mutagênica expressa pela média do número de revertentes, desvio padrão e razão de mutagenicidade (valor entre parênteses) na linhagen, TA102 de $S$. typhimurium expostas a várias doses dos ligantes, com (+S9) ou sem (-S9) ativação metabólica. .71

Tabela 5 : Atividade mutagênica expressa pela média do número de revertentes, desvio padrão e razão de mutagenicidade (valor entre parênteses) na linhagen, TA98 de $S$. typhimurium expostas à várias doses dos compostos e cis-platina, com $(+\mathrm{S} 9)$ ou sem (S9) ativação metabólica.

Tabela 6 : Atividade mutagênica expressa pela média do número de revertentes, desvio padrão e razão de mutagenicidade (valor entre parênteses) na linhagen, TA98 de $S$. typhimurium expostas à várias doses dos ligantes, com (+S9) ou sem (-S9) ativação metabólica. 


\section{LISTA DE ABREVIATURAS}

${ }^{\circ} \mathrm{C}$

$\mu \mathrm{g}$

$\mu \mathrm{L}$

$\mu \mathrm{M}$

ANOVA

BSA

$\mathrm{Ca}^{2+}$

$\mathrm{CO}_{2}$

iNOS/NOS2

DMSO

dmba

ELISA

$\mathrm{H}_{2} \mathrm{O}_{2}$

$\mathrm{H}_{2} \mathrm{SO}_{4}$

$\mathrm{IC}_{50}$

IQ

IFN- $\gamma$

IL-1 $\beta$

IL-6

IL-10

IL-12

$\mathrm{L}$

LPS

$\mathrm{mL}$

$\mathrm{mM}$

MTT

$\mathrm{NaCl}$

$\mathrm{NaNO}_{2}$

$\mathrm{NaOH}$

$\mathrm{NF}-\kappa \mathrm{B}$

$\mathrm{ng} / \mathrm{mL}$

nm graus Celsius

microgramas

microlitros

micromolar

Análise de variância

Bovine serum albumin

Cálcio ${ }^{2+}$

Dióxido de carbono

Óxido nítrico sintetase induzivel

Dimetilsulfóxido

$\mathrm{N}, \mathrm{N}$ - dimetilbenzilamina

Enzyme linked immunosorbent assay

Peróxido de hidrogênio

Ácido sulfurico

Concentração inibitória de 50\%

Instituto de Química

Interferon-gama

Interleucina 1 beta

Interleucina 6

Inteleucina 10

Interleucina 12

Litro

Lipopolissacarídeo

Mililitros

Micro molar

brometo de 3-(4,5-dimetiltiazol-2-il)-2-5-difeniltetrazólico

Cloreto de sódio

Nitrito de sódio

Hidróxido de sódio

Nuclear Factor $\kappa B$

Nanogramas por mililitro

Nanômetro 
NO

$\mathrm{Pd}$

$\mathrm{Pt}$

PBS

RNI

ROI

RPMI-1640

Th1

Th2

TNF- $\alpha$

tu

UV

$x \mathrm{~g}$

$\mathrm{RM}$

TBE
Óxido nítrico

Paládio

Platina

Solução salina tamponada com fosfatos

Intermediários reativos do nitrogênio

Intermediários reativos do oxigênio

Roswell Park Memorial Institute (meio de cultura - série 1640)

Tipo de linfócito T helper

Tipo de linfócito T helper

Fator de necrose tumoral alfa

Tiouréia

Ultravioleta

Força Centrífuga Relativa

Razão de Mtagenicidade

Tampão Tris/Borato/EDTA 


\section{Compostos Organometálicos}

$[\mathrm{Pd}(\mathrm{dmba})(\mathrm{Cl}) \mathrm{tu}]-$ denominado composto 1<smiles>NC(=S)S</smiles>

tu = tiouréia

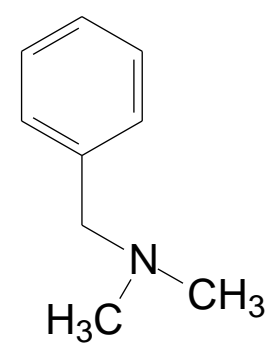

$\mathrm{dmba}=\mathrm{N}, \mathrm{N}$-dimetilbenzilamina

[Pd(dmba)(N3)tu]- denominado composto 2 


\section{SUMÁRIO}

\section{RESUMO}

ABSTRACT

LISTA FIGURAS

LISTA DE TABELAS

LISTA DE ABREVIATURAS

CAPÍTULO 1

1. INTRODUÇÃ O.............................................................................................................20

2. REVISÃO BIBLIOGRÁFICA..................................................................................25

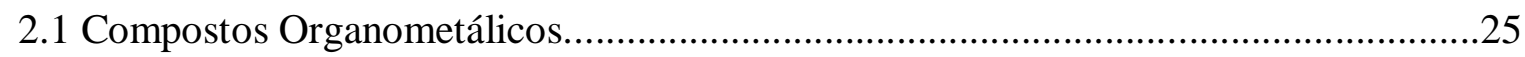

2.2 Sistema Imune X Câncer....................................................................................26

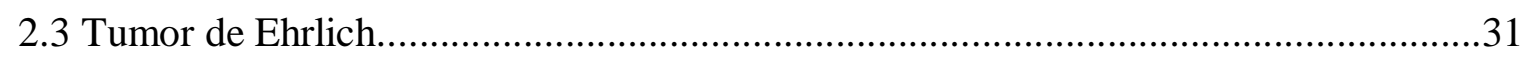

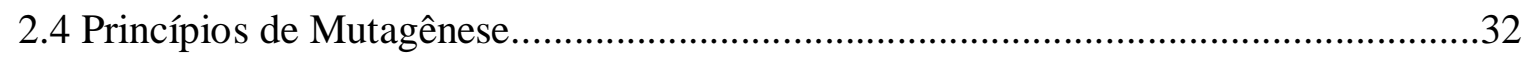

3.OBJETIVO......................................................................................................................................36

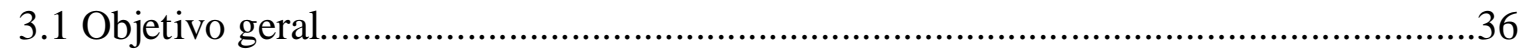

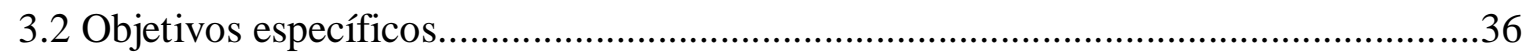

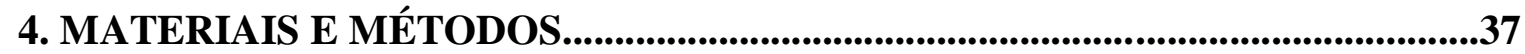

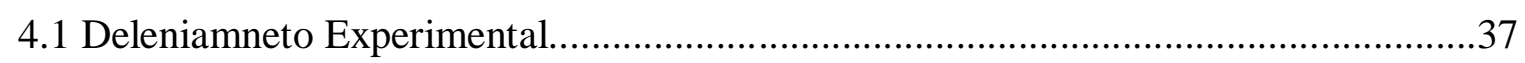

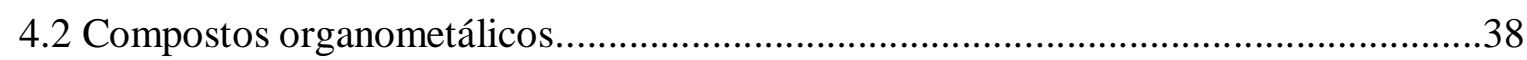

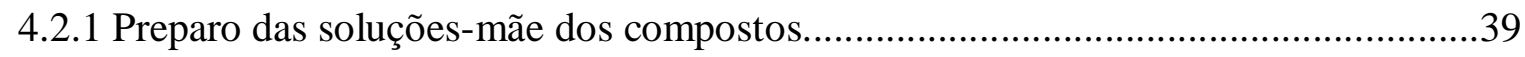

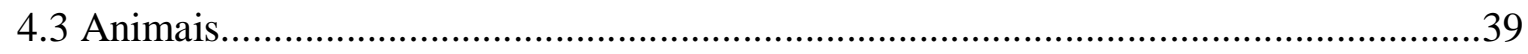

4.4 Linhagem celular tumoral utilizada e manutenção do tumor de Ehrlich in vivo..........40

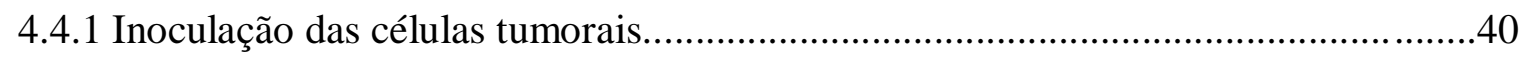

4.4.2 Determinação do volume dos tumores.............................................................40

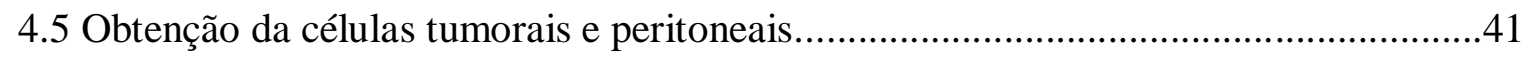

4.5.1 Isolamento das células tumorais de Ehrlich para os ensaios in vitro.........................41

4.5.2 Obtenção de células peritoneais e dos sobrenadantes das culturas............................41

4.6 Avaliação da citotoxicidade pela técnica de MTT (MOSSMAN, 1983).....................42

4.6.1 Ajuste das concentrações das suspensões de células tumorais e peritoneais.............42

4.6.2 Ensaio de viabilidade celular de células tumorais e células aderentes......................42

4.7 Determinação da produção de Óxido Nítrico (NO) ...................................................43 
4.8 Determinação da produção de Peróxido de Hitrogênio $\left(\mathrm{H}_{2} \mathrm{O}_{2}\right)$..................................44

4.9 Obtenção dos sobrenadantes das culturas de macrófagos peritoneais ........................45

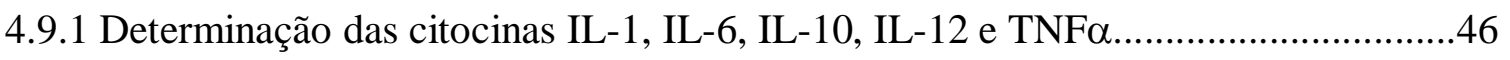

4.10 Sistemas-teste para Avaliação de Mutagenicidade....................................................47

4.10.1 Teste de Ames (Salmonella/Microsome Assay) .....................................................47

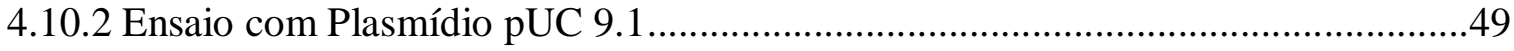

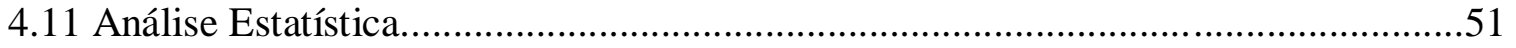

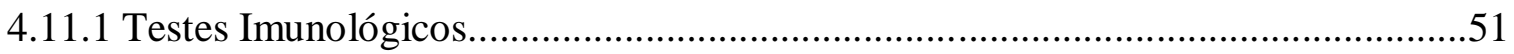

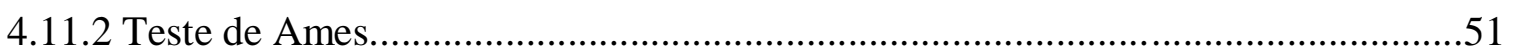

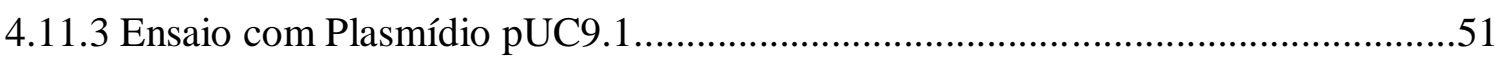

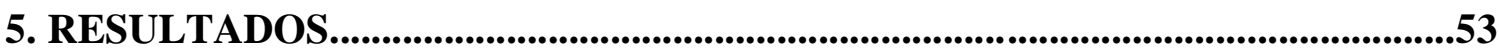

5.1 Avaliação da citotoxicidade de macrófagos peritoneais e células tumoral de Ehrlich

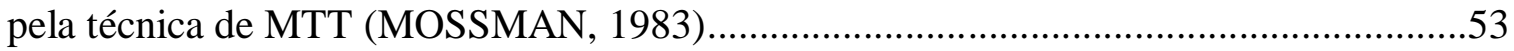

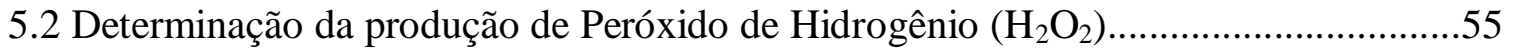

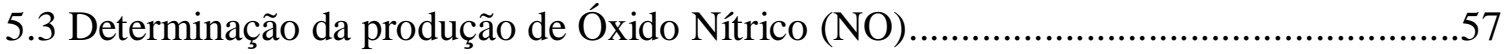

5.4 Determinação da citocina TNF- $\alpha$ nos sobrenadantes das culturas de células aderentes

5.5 Determinação da citocina IL-1 $\beta$ nos sobrenadantes das culturas de células aderentes.

5.6 Determinação da citocina IL-6 nos sobrenadantes das culturas de células aderentes

5.7 Determinação da citocina IL-12 nos sobrenadantes das culturas de células aderentes.

5.8 Determinação da citocina IL-10 nos sobrenadantes das culturas de células aderentes

5.9 Determinação da mutagenicidade pelo Teste de Ames (Salmonella/Microsome

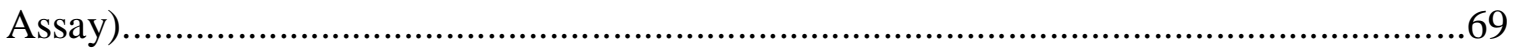

5.10 Determinação da mutagenicidade pelo Teste com plasmídio pUC9.1 …...................74

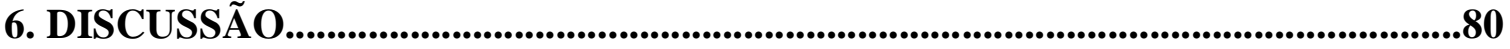

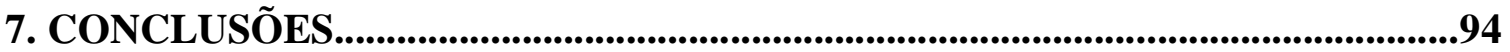

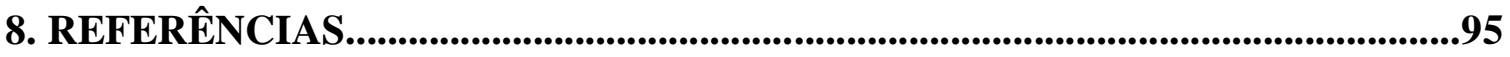

CAPÍTULO 2

ARTIGO 


\section{Capitulas}




\section{INTRODUÇÃO}

Câncer é uma doença que ataca milhões de indivíduos, e se da pelo crescimento descontrolado de células em alguma parte do corpo, sendo o câncer de mama o segundo mais freqüente no mundo e o primeiro entre as mulheres (INCA, 2009; PIVETTA, 2004).

A quimioterapia é o tratamento aplicado a mulheres que resistem ao tratamento hormonal, e uma das tentativas de inibir o crescimento do câncer é deter o fluxo de informação genética, sendo a cis-platina um dos complexos de maior sucesso na área da terapêutica. Este complexo tem a capacidade de se introduzir nas cadeias de DNA do núcleo das células. Como consequência a célula deixa de se replicar o que permite que a cis-platina seja um instrumento eficaz na cura do câncer (KOMEDA et al., 2003).

Embora a cisplatina seja um dos cinco agentes antitumorais mais utilizados em terapia clínica (O`DWYER et al., 1999) esta possui várias limitações, incluindo toxicidade (nefrotoxicidade, neurotoxicidade, ototoxicidade e emetogenesis) e resistência intrínseca ou adquirida (REEDIJK, 1996). Sendo assim o uso de compostos químicos vem sendo amplamente utilizado na área médica, por sua vasta aplicação frente a células cancerosas.

Os complexos organometálicos de paládio (II) são intensamente investigados a décadas, e tem despertado recentemente grande interesse na aplicação dos mesmos como agentes antineoplásicos por produzirem complexos estáveis o suficiente para permitirem uma eficaz ação da droga no organismo em concentrações muito baixas em relação aos compostos análogos de platina e com reduzida citotoxicidade (ANANIAS et al., 2003).

Para investigar a ação de compostos químicos se faz necessário a utilização de animais e o tumor de Ehrlich foi o modelo de escolha para o desenvolvimento do trabalho. O tumor de Ehrlich é uma espécie específica de neoplasia transplantável que 
corresponde ao adenocarcinoma mamário de camundongos. Cresce em várias espécies de camundongos, em uma forma ascítica, quando inoculado na cavidade peritoneal e na forma sólida quando inoculados por via subcutânea (EHRLICH, 1932).

Atualmente a investigação da atividade biológica envolvendo interações entre complexos inorgânicos com DNA e RNA é predominante na literatura, e são escassos os estudos que tratam da ativação de macrófagos no sistema imune por estas espécies químicas (ALLAVENA et al., 2008). Dentro deste sistema, os macrófagos são células pertencentes à imunidade inata que possuem várias funções tais como a eliminação de corpos estranhos, apresentação de antígenos e ativação das células T através da produção de citocinas (ADAMS e HAMILTON, 1984; MACKANESS, 1962). A ativação dos macrófagos é um evento chave na imunidade inata para iniciação e propagação de reações defensivas contra patógenos, porém a ativação descontrolada destas e de outras células do sistema imune pode resultar em condições patológicas de inflamações crônicas (MANTOVANI, 2009).

Da mesma maneira, em tumores, a ativação de oncogenes pode orquestrar a produção e/ou o recrutamento de células inflamatórias (MANTOVANI, 2009). Nesse contexto, a resposta imunológica é de fundamental importância no desenvolvimento e erradicação dos mesmos. Durante o processo inflamatório, os macrófagos caracterizamse pelo aumento da capacidade fagocítica e de gerar reativos intermediários do oxigênio (ROIs), nitrogênio (RNIs) e citocinas, ainda evidências indicam, que esses macrófagos ativados são capazes de destruir células tumorais (EBERHARDET, 2001; JANEWAY, 2006). As citocinas e produtos microbianos afetam diferentemente a função destas células ativando ou desativando-as (MANTOVANI et al., 2004).

O óxido nítrico é produto de macrófagos ativados e é derivado do aminoácido Larginina pela atividade enzimática da óxido nítrico sintase induzível (iNOS ou NOS2) e 
funciona como uma molécula tumoricida e antimicrobiana in vitro e in vivo, promovendo inibição da proliferação e redução da progressão metastática (BOGDAN, 2001; GALLI, et al., 2003). Enquanto que a geração de $\mathrm{H}_{2} \mathrm{O}_{2}$ é um processo natural, resultante de várias reações específicas essenciais à atividade celular. Entretanto, a liberação de quantidades significativas de $\mathrm{H}_{2} \mathrm{O}_{2}$ induz a quebra da fita de DNA e/ou perturbação no citoesqueleto da membrana, levando à morte celular (RAMASARMA, 1990).

As espécies reativas de oxigênio podem lesar o tecido do hospedeiro especialmente na vizinhança do sítio inflamatório. Têm-se relatado seu envolvimento em danos a tecidos associados com doenças inflamatórias incluindo a artrite reumatóide, aterosclerose, catarata, diabetes mellitus, câncer, dentre outras (BERGENDI et al., 1999; KARPUZOGLU e AHMED, 2006).

Além do $\mathrm{NO}$ e $\mathrm{H}_{2} \mathrm{O}_{2}$, outros mediadores estão envolvidas em processos inflamatórios. As citocinas interleucina-1 (IL-1), interleucina-6 (IL-6), interleucina-12 (IL-12) e fator de necrose tumoral-alfa (TNF- $\alpha$ ) são conhecidas por serem citocinas próinflamatórias que possuem uma multiplicidade de atividades biológicas ligadas a imunopatogenicidade de doenças inflamatórias crônicas e agudas (RIGBY et al., 2007).

O TNF- $\alpha$ pode induzir morte por necrose ou apoptose em algumas células tumorais humanas primárias e em linhagens celulares tumorais (PALLADINO et al., 2003), incluindo linhagens de câncer de mama (BEN-BARUCH, 2003). A IL-1 induz a proliferação e a ativação de macrófagos, e também possui a capacidade de aumentar a citotoxicidade e inibir o crescimento das células tumorais do câncer de mama e melanoma (LASKIN et al., 2001; KUNINAKA et al, 2000). A IL-6, por sua vez, é uma citocina chave para o crescimento tumoral, além de desempenhar função próinflamatória e anti-apoptótica em ratos (NAUGLER et al., 2007). A IL-12 é uma 
citocina multifuncional que estimula a imunidade inata e adaptativa direcionando o sistema imune à resposta imune $\mathrm{Th}_{1}$, necessária à eliminação tumoral. As funções imunomoduladoras e antiangiogênicas da IL-12 justificam esta citocina como um agente antineoplásico. (BARNES, 2003; BERRAONDO et al., 2009).

Contrária às citocinas citadas acima, a interleucina 10 (IL-10) é uma molécula produzida principalmente por macrófagos e linfócitos que expressam propriedades antiinflamatórias reduzindo a amplificação dos processos inflamatórios (NAUNDORF et al., 2009).

Além da avaliação da atividade imunomoduladora, outro aspecto importante a ser analisado é o efeito de substâncias antitumorais sobre o DNA (ácido desoxirribonucléico). As mutações despertam grande interesse por estarem diretamente relacionadas ao desenvolvimento de diversas doenças degenerativas tais como o câncer e arteriosclerose (DE FLORA, 1998; SEO et al., 2000).

A conversão de células normais em células neoplásicas normalmente envolve vários passos. Uma das fases iniciais desse processo envolve a ação de um carcinógeno genotóxico (WEISBURGER, 2000). O interesse na identificação de produtos químicos que possam ter propriedades antimutagênicas e anticarcinogênicas tem aumentado gradativamente, pois o conhecimento de tais produtos pode ser útil como medida preventiva para o ser humano no combate de vários males. O descobrimento de produtos que reduzem a taxa de mutações fatalmente diminuiria a incidência de câncer e outras doenças degenerativas, pois o homem poderia aumentar a exposição a determinados agentes antimutagênicos efetivos (HAYATSU et al, 1998; DEARFIELD et al., 2002).

Sabendo-se que compostos de paládio (II) de complexos organometálicos de paládio (II) de fórmula geral $\mathrm{Pd}(\mathrm{dmba})(\mathrm{Cl}) \mathrm{tu}]$ e $\left[\mathrm{Pd}(\mathrm{dmba})\left(\mathrm{N}_{3}\right)\right.$ tu], e seus ligantes dmba $=\mathrm{N}, \mathrm{N}$-dimetilbenzilamina $\mathrm{e} \mathrm{tu}=$ tiouréia, podem apresentar potenciais atividades 
antitumorais, o presente trabalho buscou avaliar a ação destes sobre as células da linhagem tumoral de Ehrlich e macrófagos in vitro. 


\section{REVISÃO BIBLIOGRÁFICA}

\subsection{Compostos Organometálicos}

Os últimos anos evidenciam um crescente interesse na química de compostos organometálicos, notadamente dos ciclometalados, pelas suas vastas e diversificadas aplicações como em processos catalíticos, materiais mesogênicos, na área médica e mais recentemente na química supramolecular. O termo ciclometalado, introduzido por Trofimenko (1973), descreve reações nas quais ligantes orgânicos sofrem uma reação de metalação intramolecular levando à formação de um anel quelato, com uma ligação de coordenação entre o metal $\mathrm{M}$ e um átomo doador $\mathrm{Y}$ dos grupos $\mathrm{V}(\mathrm{N}, \mathrm{P}, \mathrm{As})$ ou VI $(\mathrm{O}$, $\mathrm{S}, \mathrm{Se}$ ), e uma ligação covalente metal-carbono, sendo X um halogênio ou grupo alquil, como ilustrado na Figura 1. Na química medicinal, destacam-se atualmente os derivados do Pd(II), sobre os quais há muitas citações contemplando espécies organopaladadas mono, bi e polinucleares com propriedades biológicas como o organopaladado contendo o ligante derivado da tiosemicarbazona, $\left[\mathrm{Pd}\left(\mathrm{C}_{9} \mathrm{H}_{11} \mathrm{~N}_{3} \mathrm{~S}\right) \mathrm{Cl}_{2}\right]$, que apresentou atividade citotóxica in vitro frente a certos tipos de células cancerígenas, sendo a mesma superior àquela do análogo com platina (II) ( ANANIAS et al., 2003; MORO et al., 2004).

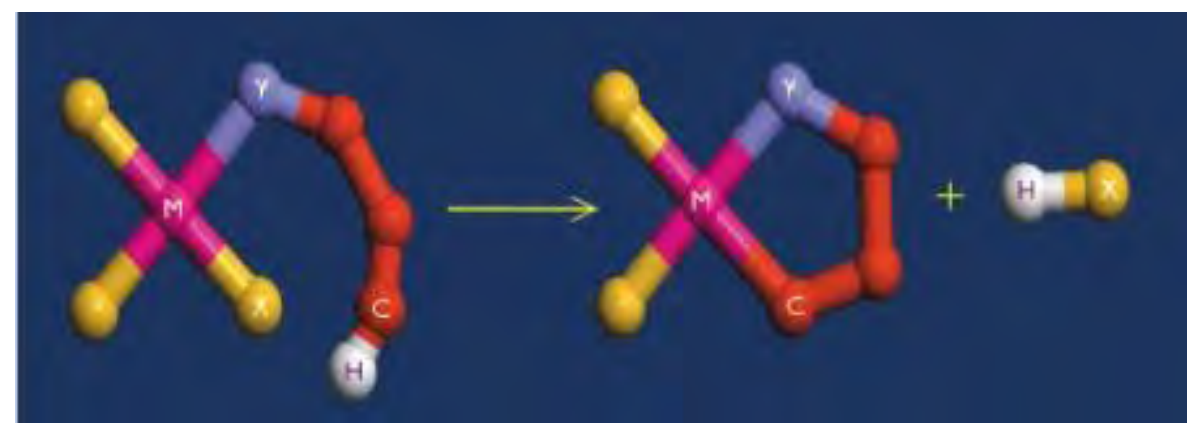

Figura 1: Representação esquemática da formação do anel ciclometalado

Devido aos problemas significativos apresentados pela cis-pt e derivados, a pesquisa por drogas antitumorais tem caminhado em direção ao desenvolvimento estruturalmente racionalizado de novos compostos, como os organopaladados 
mononucleares investigados recentemente, $[\mathrm{Pd}(\mathrm{dmba})(\mathrm{X})(\mathrm{dppp})], \mathrm{dmba}=\mathrm{N}, \mathrm{N}-$ dimetilbenzilamina, dppp =1,3-bis(difenilfosfina) propano, $\mathrm{X}=\mathrm{CL}, \mathrm{N}_{3}, \mathrm{NCO}, \mathrm{SCN}$, os quais promoveram a ativação de macrófagos (DE ALMEIDA et al., 2005). A coordenação de determinados ligantes ao paládio (II), tais como a N,N'dimetilbenzilamina (dmba) e a 1,3-bis(difenilfosfina) propano (dppp), potencializou a atividade antitumoral de seus complexos. No que diz respeito à nuclearidade dos complexos, a reação de clivagem dos dímeros de fórmula geral $[\operatorname{Pd}(\mathrm{N}, \mathrm{C}-\mathrm{dmba})(\mu-\mathrm{X})]_{2}$, $\mathrm{X}=\mathrm{CL}, \mathrm{NCO}, \mathrm{SCN}$ ou CL; empregando a difosfina dppp, forneceu complexos de organopaladados de fórmula geral $[\mathrm{Pd}(\mathrm{C}-\mathrm{dmba})(\mathrm{X})(\mathrm{dppp})]$. Estes, por sua vez, tiveram suas citotoxicidades avaliadas frente a culturas de macrófagos peritoneais murinos e células de tumor mamário experimental in vitro da linhagem LMM3 apresentando potenciais citotóxicos similares ou superiores a cis-platina (COSTA, 2004). Os compostos de fórmula geral $\left[\mathrm{Pd}\left(C^{2}, N \text {-dmba }\right)(\mu-\mathrm{X})\right]_{2}[\mathrm{dmba}=N, N$-dimethylbenzylamina; $\mathrm{X}=$ $\mathrm{Cl}, \mathrm{Br}]$ e $\left[\mathrm{Pd}\left(C^{2}, N\right.\right.$-dmba $\left.)(\mathrm{X}) \mathrm{tu}\right][\mathrm{X}=\mathrm{Cl}, \mathrm{Br}]$ apresentaram potencial citotóxico in vitro frente a linhagem LM3 e LP07 (linhagem tumoral de mama e pulmão) respectivamente, dados obtidos em pesquisas realizadas em nosso laboratório (ANANIAS, et al., 2003; MORO, et al., 2009).

\subsection{Sistema Imune versus Câncer}

Câncer é o termo utilizado para se referir a mais de 100 tipos de doenças nas quais células que sofreram alterações genéticas, chamadas então de neoplásicas ou cancerígenas, se dividem sem controle, podendo invadir tecidos do organismo por meio da circulação sangüínea e do sistema linfático (M"ERIC et al., 2006). É uma das principais causas de morte em todo mundo, estimando-se que 84 milhões de pessoas irão morrer de câncer entre 2005 e 2015 (WHO, 2009). 
O câncer de mama é o tipo de câncer mais comum entre as mulheres nos Estados Unidos e a segunda causa de morte entre todos os tipos cânceres. No Brasil, segundo o Instituto Nacional do Câncer (INCA), 49.400 novos casos de câncer de mama são estimados para 2008 e 2009 (INCA, 2009).

Extensas investigações vêm sendo realizadas sobre a imunologia da neoplasia, sugerindo que a imunidade pode ser um fator de grande importância na resistência do hospedeiro ao câncer. Evidências indicam que a incidência do câncer seria bem maior se não fosse a vigilância exercida pelo sistema imune, estando esse conceito apoiado em vários argumentos tais como: uma grande incidência de malignidade em pacientes com deficiência no sistema imune mediado por células; uma maior incidência em animais timectomisados e inoculados com vírus oncogênicos ou com células tumorais; uma alta incidência em pacientes sob tratamento com imunosupressores (SAKAGAMI et al., 1997; VERNOOY et al., 2002; KLOTZ et al., 2005).

A presença de anticorpos humorais e respostas celulares específicas contra uma grande variedade de tumores indicam que o hospedeiro pode ativar uma resposta imune contra tecidos neoplasicos. O processo, entretanto, pode apresentar dois caminhos distintos, isto é, se por um lado a resposta imune pode favorecer o hospedeiro estando assim correlacionada com o decréscimo do processo tumoral, por outro lado foi experimentalmente demonstrado que naturalmente ou após a imunoterapia pode ocorrer a formação de anticorpos que atuam favorecendo o tumor, facilitando o seu desenvolvimento (COUSSENS \& JACKS, 2008).

Quanto à imunidade celular, processo eficaz na destruição dos tumores, é composta por células imunológicas que são capazes de liberar milhares de substâncias que tem como objetivo amplificar o processo inflamatório (MILLS, et.al, 2004). Dentre 
estas células os macrófagos desempenham papel chave na contenção do agente agressor, sendo uma das principais células que compõe o sistema imune inato.

Durante o processo inflamatório, os macrófagos exercem três funções principais: fagocitose, apresentação de antígenos e imunomodulação através da produção de várias citocinas e fatores de crescimento. Os macrófagos inflamatórios diferem dos macrófagos residentes especialmente pelo aumento da capacidade fagocítica e pela habilidade aumentada de gerar reativos intermediários de oxigênio (ROIs) e nitrogênio (RNIs), ainda evidências indicam, que macrófagos ativados são capazes de destruir células tumorais (EBERHARDET, 2001; JANEWAY, 2006). As citocinas e produtos microbianos afetam diferentemente a função destas células ativando ou desativando-as (MANTOVANI et al., 2004).

Nos macrófagos, o LPS é o estímulo melhor caracterizado para a indução de genes transcricionais codificadores de proteínas pró-inflamatórias. O óxido nítrico é produto de macrófagos ativados e é derivado do aminoácido L-arginina pela atividade enzimática do óxido nítrico sintase induzível (iNOS ou NOS2) e funciona como uma molécula tumoricida e antimicrobiana in vitro e in vivo, promovendo inibição da proliferação e redução da progressão metastática (BOGDAN, 2001; GALLI, et al., 2003).

Dentre os reativos intermediários de nitrogênio, a geração de peróxido de hidrogênio $\left(\mathrm{H}_{2} \mathrm{O}_{2}\right)$, se faz importante na destruição de microrganismos invasores e células cancerígenas. Durante a fagocitose, há um aumento no consumo de oxigênio pelos neutrófilos. Neste fenômeno, conhecido como explosão respiratória, $\mathrm{o}^{-} \mathrm{O}_{2}^{-}$é produzido pela redução de 1 elétron do $\mathrm{O}_{2}$, promovida pela nicotinamida adenina dinucleotídeo fosfato (NADPH), o doador específico de elétrons. Uma porção 
significativa do $\mathrm{O}_{2}^{-}$produzido é liberada para o meio extracelular, onde ocorre uma dismutação espontânea que resulta na formação do $\mathrm{H}_{2} \mathrm{O}_{2}$ (DAHLGREN e KARLSSON, 1999; HALLIWELL e GUTTERIDGE, 1999).

Da variedade de espécies reativas de oxigênio e nitrogênio geradas durante o estresse oxidativo, o peroxinitrito (ONOO-) é um dos mediadores mais potentes e tóxicos (BECKMAN e KOPPENOL, 1996), produzido por associação espontânea de $\mathrm{NO}{\mathrm{e} \mathrm{O}_{2}^{-}}_{2}$ que são liberados durante vários processos patológicos em que ocorre a produção de óxido nítrico e peróxido de hidrogênio (FERDINANDY, 2006). O peroxinitrito é um oxidante poderoso, qual pode causar danos teciduais levando a peroxidação lipidica e nitração de proteínas contendo resíduos de tirosina, favorecendo assim a toxicidade celular (BILLACK, 2006).

As citocinas são peptídeos endógenos de pequeno peso molecular amplamente envolvidos na resposta imune. Estas moléculas solúveis liberadas por linfócitos e células do sistema fagocitário, são essenciais na comunicação intercelular e em muitos processos fisiológicos e fisiopatológicos, possuem também um importante papel na patogênese de uma variedade de doenças inflamatórias e auto-imunes (DINARELLO et al., 1998; FELDMANN et al.,1996; GIBSON, 2004; OPPENHEIM et al., 1994; SCHACHNA, 2004). O microambiente tumoral está imerso por citocinas que afetam a proliferação e diferenciação de células do sistema imune, e também outros tipos de células, incluindo células epiteliais e células mesenquimais, dentre estas, citocinas proinflamatórias como IL-1, TNF- $\alpha$, IL-6 que produzidas localmente ou sistemicamente afetam a metástase de células tumorais e ao mesmo tempo amplifica a resposta imune (KUNINAKA et al., 2000; CHOI et al., 2008).

O TNF- $\alpha$ é uma citocina que possui importantes efeitos biológicos em uma variedade de células, efeitos na maioria relacionados a processos imunomodulatórios e 
inflamatórios (CASALE et al., 1996) podendo induzir morte por necrose ou apoptose em algumas células tumorais humanas primárias e em linhagens celulares tumorais (CARSWELL et al., 1975; AGGARWAL \& NATARJAN, 1996; PALLADINO et al., 2003).

A IL-1 é produzida principalmente por monócitos e macrófagos e possui uma gama de atividades biológicas, entre elas, o aumento da quimiotaxia de linfócitos $\mathrm{T}$ e $\mathrm{B}$, estimulação das sínteses de tromboxanos por neutrófilos e macrófagos, indução de proteínas de fase aguda, ativação de linfótito $\mathrm{T}$ e aumento da produção de anticorpos pelas células B (MIZEL, 1982; FALKOFF et al., 1983; DINARELLO, 1988; BIRD et al., 2002). A IL-6, por sua vez, é uma citocina que funciona em ambas as imunidades adaptativa e inata. Esta molécula é sintetizada por fagócitos mononucleares, células endoteliais vasculares, fibroblastos. Na imunidade inata, esta molécula estimula a síntese de proteínas de fase aguda por hepatócitos contribuindo desta maneira com o efeito sistêmico da inflamação. Na imunidade adaptativa, esta citocina estimula a diferenciação de linfócito B em células produtoras de anticorpos (plasmócitos). (ABBAS et al., 2003; NAUGLER et al., 2007).

A IL-12 é uma citocina produzida por macrófagos e outras células apresentadoras de antígeno em resposta a estimulação por uma série de microrganismos e seus produtos. Possui atividades biológicas múltiplas principalmente através de linfócitos T e células NK, induzindo a produção de inteferon- $\gamma$ (IFN- $\gamma)$ (SENCHINA et al., 2005).

De maneira oposta as citocinas citadas acima, a IL-10 é produzida principalmente por macrófagos e linfócitos e está associada à diferenciação de células $\mathrm{Th}_{2}$. Sua atuação na inibição das funções de macrófagos inclui a inibição do burst oxidativo, inibição de 
NO e das citocinas TNF- $\alpha$ e IL-1 (GAZZINELI et al., 1992; OSWALD et al., 1992; NAUNDORF et al., 2009).

Assim, o estudo in vitro de macrófagos nos permite analisar os prováveis mecanismos de defesa do hospedeiro para o controle e erradicação de doença neoplásica (ADAMS e HAMILTON, 1984; KLOSTERGAARD et al., 1991).

\subsection{Tumor de Ehrlich}

O tumor de Ehrlich foi descrito por Ehrlich em 1905 (EHRLICH \& APOLANT, 1905) e descrito em 1906 como um carcinoma mamário de camundongos fêmeas. Inicialmente, o tumor foi desenvolvido experimentalmente sob a forma sólida, sendo transplantado em animais da mesma espécie. Somente em 1932, com Loewenthal \& Jahn, é que surgiu a forma ascítica, ou seja, aquela desenvolvida no peritônio de animais inoculados com células tumorais (LOEWENTHAL \& JAHN, 1932).

Devido a suas características e fácil manuseio experimental, o tumor de Ehrlich tem sido extensamente aplicado para a chamada oncologia experimental, um ramo da oncologia comparada dedicado ao desenvolvimento dos chamados tumores transplantáveis ou transmissíveis. A oncologia comparada, por sua vez, procura melhorar o conhecimento das neoplasias que afetam o homem e até mesmo os animais (DAWE, 1982).

Este tumor tem sido utilizado como um modelo para vários estudos, tais como a influência do estresse sobre câncer (PALERMO-NETO et al., 2001, PALERMO-NETO et al., 2003), resposta imunológica ao tumor (SEGURA et al. 2000; PINTO, 2003), efeito antiangiogênico e antiproliferativo (KUMAR et al., 2009), marcadores de proliferação celular (SILVA et al., 2006), na avaliação do crescimento tumoral sob o efeito de toxinas (MADY, 2002), extratos vegetais (RAJESHKUMAR et al., 2002), 
drogas antiinflamatórias (PAL et al., 2001), agentes químicos e derivados como fluoracil, cisplatina (YONEDA et al., 1999; VALADARES \& QUEIROZ, 2002) e vitaminas A e B1 (OLORIS et al., 2002).

\subsection{Princípios de Mutagênese}

O DNA é o material genético de todos os seres vivos e de muitos vírus, sendo a seqüência de bases nitrogenadas a forma na qual a informação genética é armazenada (LEWIN, 2001). Por apresentar essa função fundamental, o DNA é bastante protegido, sendo a única molécula biológica que apresenta um mecanismo próprio para prevenção e reparo de falhas em seu metabolismo (LEHNINGER et al., 1995). Entretanto, esta sujeito a mutações que são alterações súbitas no conjunto gênico de um organismo que não são explicáveis pela recombinação genética pré-existente (ZAHA et al., 1996). Estas alterações, segundo Lewin (2001) podem ser decorridas de processos celulares normais (mutações espontâneas) ou devido a exposição do organismo a agentes químicos ou físicos (mutações induzida).

As mutações despertam grande interesse por estarem diretamente relacionadas ao desenvolvimento de diversas doenças degenerativas tais como o câncer e arteriosclerose (DE FLORA, 1998; SEO et al., 2000).

A conversão de células normais em células neoplásicas normalmente envolve vários passos. Uma das fases iniciais desse processo envolve a ação de um carcinógeno genotóxico (WEISBURGER, 2000).

O teste de mutação gênica reversa com Salmonella (teste de Ames) tem sido o mais utilizado para identificar mutágenos entre substâncias puras, em misturas e em amostras ambientais. Este teste usa linhagens de bactérias contendo mutações no operon da histidina, o que as deixa incapazes de crescer na ausência deste aminoácido 
(histidina-dependentes), e também contêm um número de mutações que deixa as células mais sensíveis a xenobióticos mutagênicos (MARON e AMES, 1983).

Na presença de mutágenos, uma ou mais dessas linhagens serão mutadas para o tipo selvagem (histidina independente) e serão identificadas pela sua capacidade de crescer e formar colônias na ausência de histidina (MARON e AMES, 1983).

As mutações no operon histidina também são diferentes de acordo com a linhagem. E essas diferenças permitem identificar o mecanismo de ação de diferentes agentes químicos, isto é, determinadas linhagens identificam agentes mutagênicos que causam substituição de pares de bases e outras linhagens identificam agentes químicos que causam mutações do tipo frameshift (MARON e AMES, 1983; MORTELMANS e ZEIGER, 2000).

Entretanto, as linhagens bacterianas não apresentam enzimas de metabolização, o que impossibilita sua capacidade para identificação de agentes mutagênicos de ação indireta. Para superar essa dificuldade, adiciona-se às culturas durante os ensaios a chamada fração S9, que contém enzimas metabolizadoras de xenobióticos, e é obtida a partir do fígado de ratos (MARON e AMES, 1983).

Todas essas características conferem ao Teste de Ames (Fig.2) uma grande capacidade de identificação e caracterização de diferentes agentes mutagênicos, com grande eficiência e sensibilidade. 

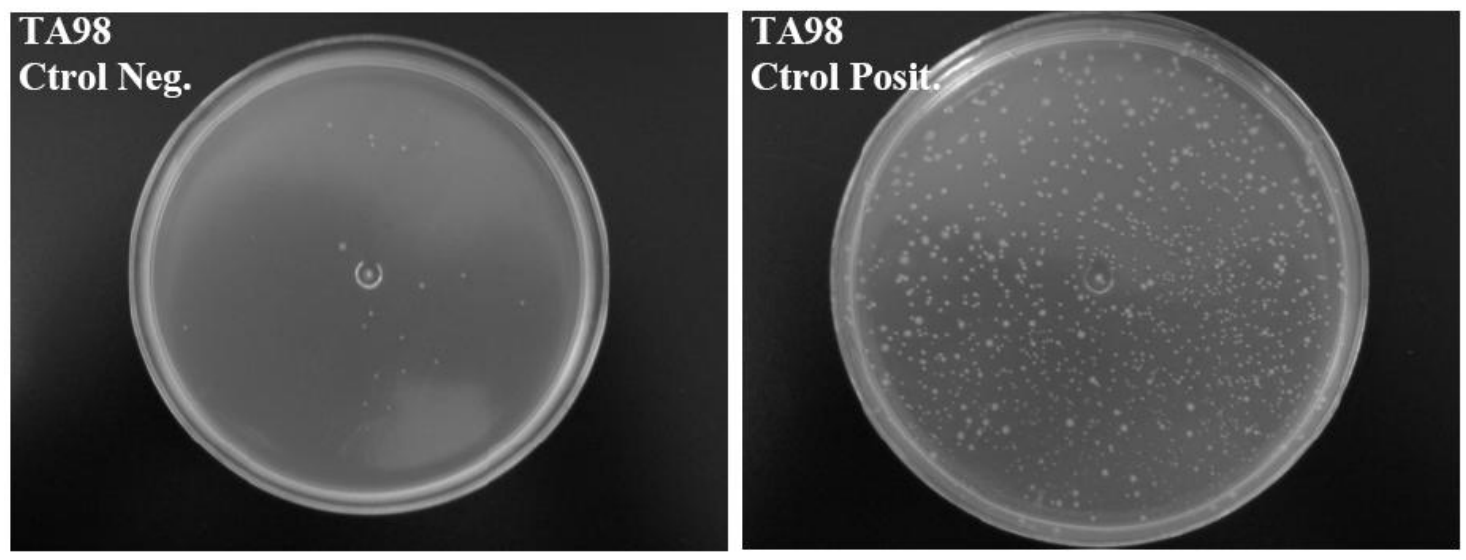

Figura 2. Placas com Salmonella typhimurium (Teste de Ames)

Já uma das maneiras de avaliar a genotoxicidade de substâncias químicas e misturas é por meio da indução de quebras no DNA, através do perfil eletroforético em gel de agarose, das diferentes conformações de DNA plasmidial - superhelicoidizada, observada no seu estado íntegro, ou circular aberta e linear, induzidas, respectivamente, por quebras em fita única ou na dupla fita do DNA - as quais migram diferencialmente pelo gel de agarose (YOSHINO et al., 1999).

O desenvolvimento de cânceres ocorre, muitas vezes, como conseqüência de mutações sucessivas e expansão do clone mutante. Mutações que inativam genes supressores de tumor, ativam pro-oncogenes e telomerases, estimulam a proliferação e inibem a morte celular, fornecem um grande estímulo na iniciação de um câncer (HAHN e WEINBERG, 2002). Mutações do tipo substituição de bases e deslocamento do quadro de leitura do DNA são encontradas nesses genes, numa grande variedade de tipos de câncer (GREENBLATT et al., 1994).

Portanto o interesse na identificação de produtos químicos que possam ter propriedades antimutagênicas e anticarcinogênicas tem aumentado gradativamente, pois o conhecimento de tais produtos pode ser útil como medida preventiva para o ser humano no combate de vários males. O descobrimento de produtos que reduzem a taxa 
de mutações fatalmente diminuiria a incidência de câncer e outras doenças degenerativas, pois o homem poderia aumentar a exposição a determinados agentes antimutagênicos efetivos (HAYATSU et al, 1998; DEARFIELD et al., 2002). 


\section{OBJETIVO}

\subsection{Geral}

O presente trabalho teve como objetivo geral avaliar a citotoxicidade e a mutagenicidade de complexos organometálicos de paládio (II) de fórmula geral $\operatorname{Pd}(\mathrm{dmba})(\mathrm{Cl}) t \mathrm{tu}]$ e $[\mathrm{Pd}(\mathrm{dmba})(\mathrm{N} 3) t u]$, e seus ligantes dmba $=\mathrm{N}, \mathrm{N}$-dimetilbenzilamina e tu $=$ tiouréia.

\subsection{Específicos}

a) Avaliar o índice de citotoxicidade mediano $\left(\mathrm{IC}_{50}\right)$ dos compostos, ligantes e cisplatina sobre as células aderentes de animais não portadores, animais portadores do tumor de Ehrlich na sua forma sólida e sobre as células tumorais de Ehlich in vitro.

b) Avaliar a produção de óxido nítrico (NO), peróxido de hidrogênio $\left(\mathrm{H}_{2} \mathrm{O}_{2}\right)$ e citocinas tais como TNF- $\alpha$, IL-1 $\beta$, IL-6, IL-12, IL-10, sobre as células aderentes de animais não portadores e animais portadores do tumor de Ehrlich na sua forma sólida.

c) Avaliar a atividade mutagênica dos compostos, ligantes e cis-platina, empregando-se o teste de Ames, utilizando a linhagem TA102 e TA98, em ausência e presença de metabolização e através de ensaios com plasmídio pUC9.1. 


\section{MATERIAIS E MÉTODOS}

\subsection{Deleniamento Experimental}
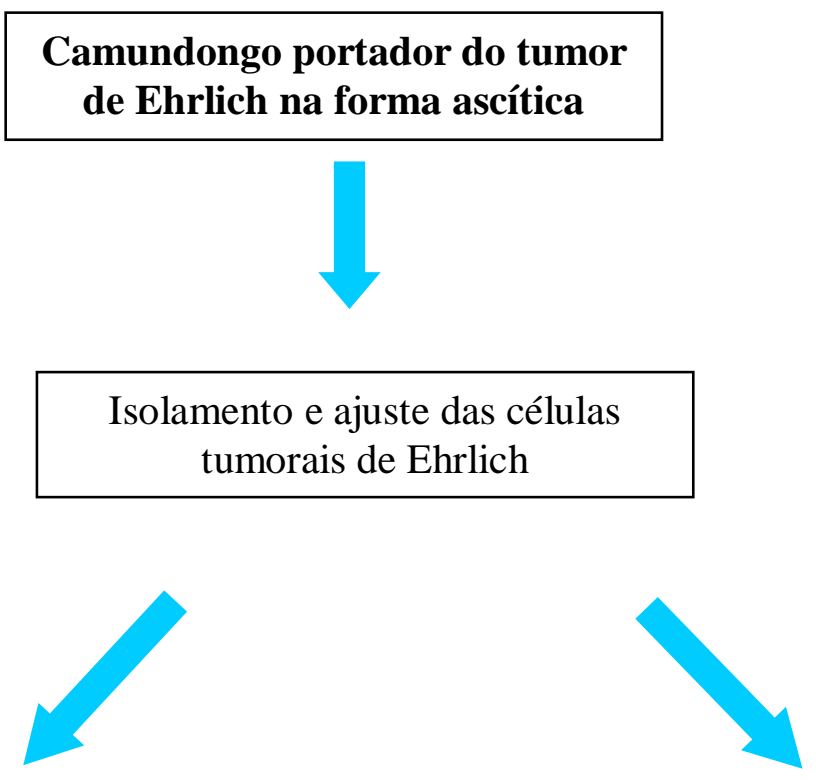

Ensaio de citotoxicidade dos compostos sobre as células tumorais de Ehrlich
Inoculação subcutânea dos camundongos com as células tumorais de Ehrlich

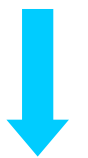

Determinação do índice de citotoxicidade mediano $\left(\mathrm{IC}_{50}\right)$ dos compostos, ligantes e cis-pT em células tumorais de Ehrlich
Crescimento do tumor de Ehrlich na forma sólida (Volume final $=0,5 \mathrm{~cm}^{3}$ ) 


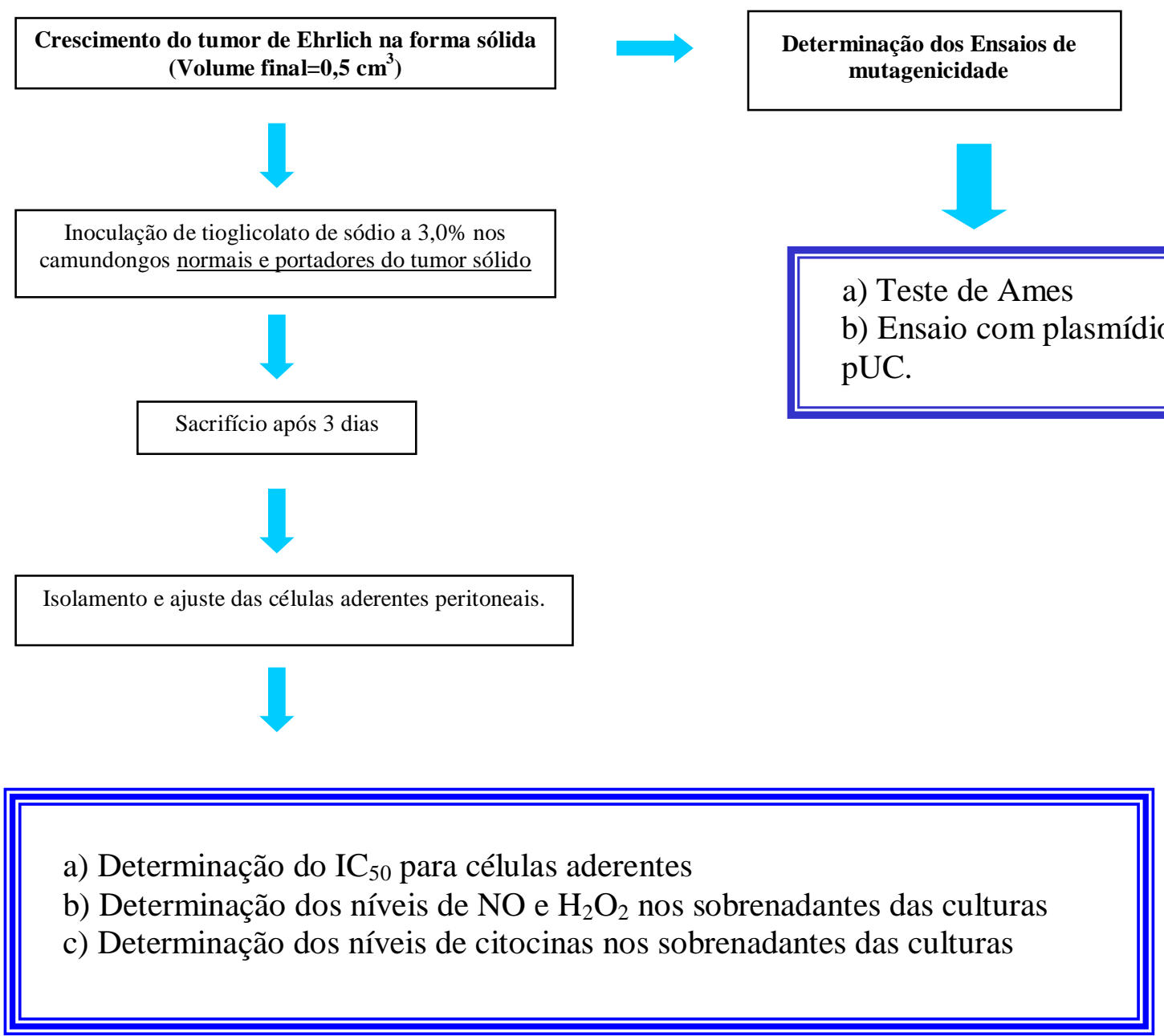

\subsection{Compostos organometálicos}

Os complexos organometálicos utilizados neste trabalho foram sintetizados no Laboratório de Organometálicos e Química de Coordenação, sob a supervisão do Prof. Dr. Antonio Eduardo Mauro, no Departamento de Química Geral e Inorgânica do Instituto de Química de Araraquara, UNESP. Os métodos para obtenção dos complexos estão descritos na literatura (DE LUCCA NETO et al., 1999; CAIRES et al., 1999; DE ALMEIDA et al., 2005).

Os compostos utilizados foram: $[\mathrm{Pd}(\mathrm{dmba})(\mathrm{Cl}) t \mathrm{tu}]$ e $\left[\mathrm{Pd}(\mathrm{dmba})\left(\mathrm{N}_{3}\right) \mathrm{tu}\right]$, nos quais dmba $=\mathrm{N}, \mathrm{N}$-dimetilbenzilamina e tu = tiouréia. Também foi utilizado a cis-platina (cisPt), fabricada por F H Faulding \& Companhia Ltda - Austrália; lote: M191881. 


\subsubsection{Preparo das soluções-mãe dos compostos}

As massas das amostras foram solubilizadas em dimetilsulfóxido [(DMSO), Merck, Alemanha] tratado conforme métodos convencionais (PERRIN et al., 1993). As soluções-mãe foram preparadas em DMSO (Merck, Alemanha) tal que, em cada concentração desejada dos compostos, a concentração final deste fosse de $0,5 \% \mathrm{v} / \mathrm{v}$ (DMSO/RPMI), tanto nos testes com células tumorais de Ehrlich como os macrófagos peritoneais obtidos de camundongos portadores do tumor de Ehrlich na forma sólida. As soluções-mãe foram diluídas em meio de cultura RPMI - 1640 suplementado com 5\% de soro fetal bovino, $100 \mu \mathrm{g} / \mathrm{ml}$ de estreptomicina, $100 \mathrm{U} / \mathrm{ml}$ de penicilina e $5 \times 10^{-2} \mathrm{M}$ de $\beta$ - mercaptoetanol, designado como RPMI - Completo [(RPMI - 1640 - C), Sigma Chemical Co., EUA] momentos antes de cada ensaio. Empregaram-se concentrações de 1000 a $6000 \mu \mathrm{M}$, para determinação da viabilidade celular frente a culturas de células tumorais e macrófagos. Dependendo dos resultados, os intervalos de concentração variaram para cada espécie organopaladada testada.

Nos ensaios de mutagenicidade (Teste de Ames, Ensaio com plasmídio pUC 9.1) foram testadas 5 concentrações dos diferentes compostos. As doses foram determinadas em estudos de triagem, testando-se doses decrescentes obtidas a partir do limite de solubilidade (maior concentração possível) de cada um dos compostos. Todos os compostos avaliados foram diluídos em dimetilsulfóxido (DMSO).

\subsection{Animais}

Foram utilizados camundongos fêmeas da linhagem Swiss de seis semanas, pesando entre 18 e 25g, fornecidos pelo Biotério Central da Faculdade de Ciências Farmacêuticas - UNESP - Câmpus de Araraquara. Os animais foram mantidos em gaiolas de policarbonato, com água e ração (Purina) ad libitum em local climatizado, (23 
$\pm 2^{\circ} \mathrm{C}, 56 \pm 2 \%$ de umidade relativa do ar), com controle de claro e escuro a cada período de $12 \mathrm{~h}$. Todos os procedimentos com animais foram conduzidos conforme parecer do Comitê de Ética local (parecer n²1/2007).

\subsection{Linhagem celular tumoral utilizada e manutenção do tumor de Ehrlich in vivo}

A manutenção das células tumorais no laboratório se deu na forma ascítica in vivo através de repiques semanais. Para manutenção do tumor in vivo, $1 \times 10^{7}$ células tumorais em um volume de $0,2 \mathrm{~mL}$ foram inoculadas intraperitonealmente em camundongos receptores, a cada 7 dias, segundo metodologia descrita na literatura (FECCHIO et al., 1990).

\subsubsection{Inoculação das células tumorais}

Os camundongos, após assepsia local com álcool iodado, foram inoculados subcutaneamente com $0,1 \mathrm{~mL}$ da suspensão tumoral ajustada na concentração de $1 \times 10^{7}$ células tumorais/mL em RPMI-1640.

\subsubsection{Determinação do volume dos tumores}

Após o desenvolvimento dos tumores, foram realizadas medidas semanais dos diâmetros das massas tumorais. Cada animal teve a pele esticada na região abdominal e com auxilio de paquímetro digital (Mitutoyo Sul Americana Ltda, Ind. Bras.) foi realizada a medida do comprimento do nódulo, quando o volume tumoral havia atingido aproximadamente $0,5 \mathrm{~cm}^{3}$, os animais foram sacrificados (ZHOU et al., 1995). 


\subsection{Obtenção de células tumorais e peritoneais}

\subsubsection{Isolamento das células tumorais de Ehrlich para os ensaios in vitro}

Após 5 dias de evolução do tumor, período no qual ainda não há influxo significativo de células inflamatórias (Fecchio et al., 1990), houve o sacrifício dos camundongos portadores do tumor de Ehrlich na forma ascítica em câmara de $\mathrm{CO}_{2} \mathrm{e}$ estes tiverão o fluido ascítico retirado assepticamente em fluxo laminar Classe 100 (Veco, Ind. Bras.).

Para o preparo da suspensão celular, esta foi centrifugada duas vezes com 5 volumes de cloreto de amônio $\left(\mathrm{NH}_{4} \mathrm{Cl}\right.$, Labsynth Ind. Bras. Ltda) 0,17M (SLATER et al., 1982), caso o fluido ascítico estivesse hemorrágico, e depois duas vezes com solução salina tamponada de fosfatos de pH 7,2, estéril (PBS) a 200xg durante 5 min.. Após esse procedimento, as células tumorais de Ehrlich sedimentadas forão ajustadas para os ensaios in vitro (Saad-Hossne et al., 2004).

As células tumorais sedimentadas forão ressuspendidas em $1,0 \mathrm{~mL}$ de meio RPMI - 1640 - C para os ensaios de citotoxicidade e/ou viabilidade celular in vitro, sendo ajustadas à concentração de $1 \times 10^{6}$ células/mL (Esteves-Souza et al., 2002). O número de células foi determinado por contagem em câmara hemocitométrica tipo Neubauer (Boeco, Alemanha) utilizando-se o corante azul de Tripan.

\subsection{Obtenção de células peritoneais e dos sobrenadantes das culturas}

Os animais inoculados com as células tumorais (volume tumoral $=0,5 \mathrm{~cm}^{3}$ ) e animais normais (não portadores de tumor) foram previamente estimulados pela inoculação intraperitoneal de 3,0 ml de solução de tioglicolato de sódio a 3,0\% (Difco Lab. Ltda, EUA) três a quatros dias antes do sacrifício. Após esse período, os camundongos foram eutanasiados em câmara de $\mathrm{CO}_{2}$. Os animais tiveram a pele da região abdominal retirada assepticamente em câmara de fluxo laminar classe 100 (Veco, 
ind. Bras.) e o peritôneo exposto. Em seguida, foi inoculado intraperitonealmente 5,0 ml de PBS, e após massagem peritoneal, o líquido peritoneal resultante foi coletado em seringa e agulha e transferido para um tubo cônico estéril (Corning, Inc., EUA) foi centrifugado (Centrífuga Fanem, Ind. Bras.) a 200xg durante 5 min., a temperatura ambiente, o sedimento celular obtido foi lavado três vezes com $3,0 \mathrm{ml}$ de PBS. O número de células foi determinado pela contagem em câmara hemocitométrica de Neubauer (Boeco, Germany), sendo ajustadas as concentrações exigidas para cada ensaio imunológico em meio RPMI-1640-C.

\subsection{Avaliação da citotoxicidade pela técnica de MTT (MOSSMAN, 1983)}

\subsubsection{Ajuste das concentrações das suspensões de células tumorais e peritoneais}

Todas as suspensões celulares empregadas nos ensaios de viabilidade celular serão ajustadas em meio RPMI-1640-C, sendo que as suspensões de células tumorais serão ajustadas à concentração de $1 \times 10^{6}$ células/ml; a suspensão de células peritoneais será ajustadas à concentração de $5 \times 10^{6}$ células/ml.

\subsubsection{Ensaio de viabilidade celular de células tumorais e células aderentes}

Para o ensaio de viabilidade celular foi utilizado o método baseado na capacidade que têm as células viáveis de clivar o anel tetrazólico presente no MTT (brometo de 3-(4,5-dimetiltiazol-2-il)-2,5-difenil-tetrazólio) pela ação de enzimas desidrogenases presentes na mitocôndria ativa, formando cristais de formazana (MOSMAN, 1983).

A uma placa de microtitulação de 96 cavidades de fundo plano (Corning, Inc.) foram distribuídos $100 \mu \mathrm{L}$ por cavidade das suspensões de células do exsudato peritoneal de camundongos à concentração de $5.10^{6}$ células $/ \mathrm{mL}$ ou de células tumorais à concentração $1.10^{6}$ células/mL em meio de cultura RPMI-1640-C, o sobrenadante foi descartado, e tanto sobre as células aderidas quanto sobre as células tumorais 
sedimentadas, adicionou-se em triplicata $100 \mu \mathrm{l}$ dos compostos: $[\mathrm{Pd}(\mathrm{dmba})(\mathrm{Cl}) \mathrm{tu}]$, $\left[\mathrm{Pd}(\mathrm{dmba})\left(\mathrm{N}_{3}\right) \mathrm{tu}\right]$ e dos ligantes dmba e tu, além da cis-Pt nas diferentes concentrações $(\mu \mathrm{M}), \quad 100 \mu \mathrm{L}$ de LPS a $10 \mu \mathrm{g} / \mathrm{mL}$ (Lipopolissacarídio de Escherichia coli sorotipo 0111:B4, Sigma Chemical. Co, EUA) + 100 $\mu$ L de RMPI-1640-C (controle positivo) ou somente $200 \mu \mathrm{L}$ meio de cultura RPMI-1640-C (controle negativo), em triplicata. As placas foram incubadas por $24 \mathrm{hs}$ a $37^{\circ} \mathrm{C}$ em estufa contendo tensão constante de $5 \%$ de $\mathrm{CO}_{2}$ (Forma Scientific, EUA). Após esse período de incubação, o sobrenadante foi descartado e as células aderentes lavadas com PBS e depois tratadas com $100 \mu \mathrm{L}$ de uma solução de MTT (Across Organics) a $0,5 \mathrm{mg} / \mathrm{mL}$ em RPMI-1640. A placa foi então incubada por mais $3 \mathrm{~h}$ nas mesmas condições anteriores. Após esta incubação os sobrenadantes foram descartados e as células aderentes tratadas com $100 \mu \mathrm{L}$ de isopropanol (Mallinckrodt) para solubilizar os cristais de formazana formados. A leitura da densidade ótica foi determinada em espectrofotômetro (Multiskan Ascent, Labsystems Research Tech. Div., Helsinki, Finland) em UV/visível a 540 nm com filtro de referência de $620 \mathrm{~nm}$.

A partir dos resultados obtidos com viabilidade celular, foi determinado $50 \%$ da concentração inibitória dos compostos (IC ${ }_{50}$ ), concentração do agente que reduz em 50\% a viabilidade celular, quantificada por regressão linear (concentração x viabilidade celular) com limite de confiança de $95 \%$ e o $\mathrm{IC}_{50}$ definido através de equação da reta gerada (Microcal Software Origin ${ }^{\mathrm{TM}}$ versão 7.0).

\subsection{Determinação da produção de Óxido Nítrico (NO)}

O óxido nítrico foi quantificado pelo acúmulo de nitrito em meio de cultura e medido espectrofotometricamente utilizando o reagente de Griess, constituído de $0,1 \%$ de N-1-naftil-etilenodiamina, $1 \%$ de sulfanilamida em solução de ácido fosfórico a 
2,5\%, utilizando $\mathrm{NaNO}_{2}$ como padrão (GREEN et al., 1982). Os animais foram sacrificados como descrito anteriormente. A suspensão celular foi ajustada a $5.10^{6}$ células/mL em meio de RPMI-1640-C, foram acrescentados à placa de 96 cavidades (Corning Inc., EUA) $100 \mu 1$ da suspensão celular e então incubadas em estufa (Forma Scientific, EUA) a $37^{\circ} \mathrm{C}$, com tensão constante de $7,5 \%$ de $\mathrm{CO}_{2}$ por 1 h para a formação do tapete celular. As células não aderentes foram retiradas por lavagens com o meio de cultura RPMI-1640-C e foram adicionados $100 \mu \mathrm{L}$ dos compostos: [Pd(dmba)(Cl)tu], $\left[\operatorname{Pd}(\mathrm{dmba})\left(\mathrm{N}_{3}\right) t u\right]$ e dos ligantes dmba e tu, além da cis-Pt na concentração do $\mathrm{IC}_{50}$ de 24h. Foi adicionado ainda em algumas cavidades $100 \mu \mathrm{L}$ de LPS a $10 \mu \mathrm{g} / \mathrm{mL}+100 \mu \mathrm{L}$ de células (controle positivo), $200 \mu \mathrm{L}$ de meio RPMI-1640-C à suspensão celular, como controle de células (controle negativo). A placa assim constituída foi incubada por $24 \mathrm{hs}$ em estufa a $37^{\circ} \mathrm{C}$ com tensão constante de $\mathrm{CO}_{2}$ a $5 \%$ (Forma Scientific, EUA). Após a incubação, foram retiradas alíquotas de $50 \mu \mathrm{L}$ de cada amostra, transferidas para uma outra placa e adicionados $50 \mu \mathrm{L} /$ cavidade de reagente de Griess. Após 10 minutos à temperatura ambiente e protegidas da luz, as placas foram lidas em espectrofotômetro UV/visível de microplacas (Multiskan Ascent, Labsystems Research Tech. Div., Helsinki, Finland) com filtro de 540nm. As concentrações de NO liberadas foram calculadas a partir de uma curva padrão previamente estabelecida com concentrações molares conhecidas de nitrito de sódio em meio RPMI-1640. Os testes foram feitos em triplicata e os valores expressos em $\mu$ mol de NO/5.105 células.

\subsection{Determinação da produção de Peróxido de Hitrogênio $\left(\mathrm{H}_{2} \mathrm{O}_{2}\right)$}

A produção de $\mathrm{H}_{2} \mathrm{O}_{2}$ foi determinada conforme procedimento descrito na literatura (PICK e KEISARI, 1980; PICK e MIZEL,1981). A suspensão celular foi ajustada à $2 \times 10^{6}$ células/mL em solução completa de vermelho de fenol, contendo 
140mM de $\mathrm{NaCl}$ ( Merck, Brasil); 10mM de tampão fosfato de potássio, pH 7,0; 5,5 mM de dextrose (Merck, Alemanha); 0,56 $\mathrm{mM}$ de vermelho de fenol (Berse, Brasil) e peroxidase de raiz forte, tipo II a $0,01 \mathrm{mg} / \mathrm{mL}$ (Sigma, EUA).

Em cada poço da placa de 96 cavidades (Corning Inc., EUA), foram acrescentados $100 \mu \mathrm{L}$ da suspensão celular juntamente com $50 \mu \mathrm{L}$ dos compostos e da cis-Pt na concentração do $\mathrm{IC}_{50}$ de $24 \mathrm{~h}$ por $1 \mathrm{~h}$ a $37^{\circ} \mathrm{C}$ em estufa (Forma Scientific, EUA) com tensão constante de 7,5\% de $\mathrm{CO}_{2}$. Como controles negativo foram utilizados somente células em solução completa de vermelho de fenol adicionadas de $50 \mu \mathrm{L}$ de tampão fosfato de potássio $\mathrm{pH}$ 7,0 e como controle positivo foram utilizadas somente células em solução completa de vermelho de fenol adicionadas de $50 \mu \mathrm{L}$ de uma solução de PMA a 0,2 $\mu \mathrm{M}$ (Sigma Chemical. Co, EUA). Após $1 \mathrm{~h}$ de incubação, a reação foi interrompida pela adição de $50 \mu \mathrm{L}$ de hidróxido de sódio $(\mathrm{NaOH}$, Sigma Chemical. Co., EUA) 5M, e a seguir foram feitas leitura em espectrofotômetro UV/Visível de microplacas (Multiskan Ascent, Labsystems Research Tech. Div., Helsinki, Finland) a 620nm. As amostras foram analisadas em triplicata. Os resultados foram expressos em nanomols de $\mathrm{H}_{2} \mathrm{O}_{2} / 2 \times 10^{5}$ células peritoneais, a partir de curva padrão previamente estabelecida, constituída de concentrações molares conhecidas de $\mathrm{H}_{2} \mathrm{O}_{2}$ em tampão vermelho de fenol.

\subsection{Obtenção dos sobrenadantes das culturas de macrófagos peritoneais}

Os sobrenadantes das culturas de macrófagos foram utilizados na determinação da produção das citocinas IL-1, IL-6, IL-12, IL-10 e TNF- $\alpha$. As células peritoneais foram ajustadas à concentração de $5.10^{6}$ células $/ \mathrm{mL}$ em meio RPMI-1640-C e distribuídas em placas de cultura de tecidos de 24 cavidades (Corning, Inc.). A cada cavidade foi adicionado $1 \mathrm{~mL}$ da suspensão celular e as placas foram incubadas a $37^{\circ} \mathrm{C}$ 
por 60 minutos em estufa contendo tensão constante de $7,5 \%$ de $\mathrm{CO}_{2}$ para formação do tapete celular. Após esta incubação, as células não aderentes foram retiradas por lavagens com o meio de cultura RPMI-1640-C.

Foi adicionado às células aderentes $1 \mathrm{~mL}$ de RPMI-1640-C $+1 \mathrm{~mL}$ dos compostos e da cis-Pt na concentração do $\mathrm{IC}_{50}$ de $24 \mathrm{~h}$ aos macrófagos aderidos à placa. Da mesma forma, $1 \mathrm{~mL}$ de LPS a $10 \mu \mathrm{g} / \mathrm{mL}+1 \mathrm{~mL}$ de RPMI-1640-C foi utilizado como controle positivo e $2 \mathrm{~mL}$ de RPMI-1640-C como controle negativo.

Estas placas foram novamente incubadas a $37^{\circ} \mathrm{C}$ em estufa com tensão constante de $7,5 \%$ de $\mathrm{CO}_{2}$ por mais $24 \mathrm{~h}$. Após esta incubação, o conteúdo das placas foi transferido para tubos do tipo eppendorfs que foram, em seguida, centrifugados a 7800 xg durante 10 minutos em centrífuga refrigerada (Hettich, Inc.) a $4^{\circ} \mathrm{C}$. Após a centrifugação, os sobrenadantes das culturas foram coletados, aliquotados em tubos do tipo eppendorfs e armazenados em freezer a $-80^{\circ} \mathrm{C}$ até o momento da determinação das citocinas através do teste imunoenzimatico, ELISA.

\subsubsection{Determinação das citocinas IL-1, IL-6, IL-10, IL-12 e TNF- $\alpha$.}

As citocinas IL-1, IL-6, IL-10, IL-12 e TNF- $\alpha$ foram quantificadas nos sobrenadantes obtidos das culturas de macrófagos através do teste imunoenzimático ELISA de captura para cada citocina, utilizando o Kit DuoSet ${ }^{\circledR}$, BD Pharmigen, de acordo com as instruções do fabricante. As microplacas de poliestireno de 96 cavidades (Corning Inc., EUA) foram adsorvidas com um anticorpo de captura anti-IL-1, IL-6, IL10, IL-12 e TNF- $\alpha$ de camundongo purificado obtido em ratos, na concentração de $4 \mu \mathrm{g} / \mathrm{mL}$ (100 $\mu \mathrm{L} /$ cavidade) diluído em tampão PBS e incubado "overnight" à temperatura ambiente. As placas foram lavadas 3 vezes com solução salina tamponada com fosfatos, pH 7,2 (PBS) contendo 0,05\% de Tween-20 (PBS-T). Após a lavagem, 
foram bloqueadas com $300 \mu \mathrm{L}$ de BSA a $1 \%$ em PBS (PBS/BSA, com 5\% de sacarose e $0,5 \%$ de azida sódica) à temperatura ambiente por 60 minutos e lavadas três vezes com PBS-T. Foram adicionados à placa $100 \mu \mathrm{L}$ da citocina padrão ou sobrenadantes das culturas de células peritoneais de camundongos. As placas foram incubadas à temperatura ambiente por 120 minutos, e lavadas quatro vezes com PBS/T. Em seguida, foram adicionados $100 \mu \mathrm{L} /$ cavidade de anticorpo monoclonal de cabra anti-IL-1, IL-6, IL-10, IL-12 e TNF- $\alpha$ de camundongo marcado com biotina na concentração de 400 ng/mL em diluente de reagente (1\%BSA, $0,05 \%$ de Tween 20 em tampão Tris-NaCl). As placas foram incubadas à temperatura ambiente por 120 min. e lavadas 3 vezes com PBS-T, sendo então adicionados $100 \mu \mathrm{L}$ do conjugado peroxidase-streptavidina diluído em PBS/BSA e incubadas novamente à temperatura ambiente por 30 minutos. Após esse processo, as placas foram lavadas três vezes com PBS-T e $100 \mu \mathrm{L}$ do substrato (10mM de tampão citrato-fosfato, contendo $0,4 \mathrm{mM}$ de tetrametilbenzidina [SIGMA] e 1,2 $\mathrm{mM}$ de $\mathrm{H}_{2} \mathrm{O}_{2}$ ) foram adicionados a cada cavidade. A reação foi interrompida adicionando-se $50 \mu \mathrm{L}$ de $\mathrm{H}_{2} \mathrm{SO}_{4} \quad 2 \mathrm{~N}$. A absorvância foi lida a 450nm em espectrofotômetro UV/Visível de microplacas (Multiskan Ascent, Labsystems Research Tech. Div., Helsinki, Finland) e as concentrações das citocinas foram quantificadas utilizando uma curva padrão previamente estabelecida com quantidades conhecidas de IL-1, IL-6, IL-10, IL-12 e TNF- $\alpha$ padrão. Os testes foram realizados em triplicata e os resultados expressos em $\mathrm{pg} / \mathrm{mL}$.

\subsection{Sistemas-teste para Avaliação de Mutagenicidade}

\subsubsection{Teste de Ames (Salmonella/Microsome Assay)}

Foi utilizada as linhagens TA102 e TA98 de Salmonella typhimurium, gentilmente cedidas pelo Dr. Bruce Ames da Universidade de Berkeley, Califórnia, 
USA. A cepa TA102 contém a mutação ochre TAA no gene hisG e detecta eficientemente mutágenos como formaldeído, glioxal, vários hidroperóxidos, bleomicina, fenilidrazina, raios-X, luz UV, estreptonigrina e agentes cross-link, como mitomicina-C (MARON e AMES, 1983). Já a cepa TA98 apresenta mutação no gene hisD (hisD3052) que codifica para a histidinol desidrogenase, apresentando como ponto preferencial para a reversão oito resíduos repetitivos de GC e detecta compostos mutagênicos que causam deslocamento do quadro de leitura do DNA. As cepas de $S$. typhimurium foram mantidas em tubos para congelamento $(1,5 \mathrm{~mL})$ à $-70^{\circ} \mathrm{C}$ para que se mantivessem inalteradas todas as suas características genéticas. Para cada $0,9 \mathrm{~mL}$ de cultura foi adicionado $0,1 \mathrm{~mL}$ de DMSO substância crioprotetora. A preparação do inoculo se deu com auxílio de alça de inoculação, onde uma pequena quantidade da cultura estoque congelada foi semeada em 30mL de caldo nutriente (Oxoid n. 2), incubada a $37{ }^{\circ} \mathrm{C}$, por $12-16 \mathrm{hrs}$, em banho-maria $\left(37^{\circ} \mathrm{C}\right)$ com agitação $(160 \mathrm{rpm})$, de modo a obter uma densidade de 1-2 x 109 bactérias/mL. De acordo com a metodologia de pré-incubação, desenvolvida por Maron e Ames (1983), diferentes concentrações dos compostos e cis-platina foram misturadas a $0,5 \mathrm{~mL}$ de tampão fosfato $0,2 \mathrm{M} \mathrm{pH} \mathrm{7,4,0,1}$ $\mathrm{ml}$ de cultura de bactérias e incubadas de 20-30 minutos a $37^{\circ} \mathrm{C}$. Nos ensaios com ativação metabólica, foram adicionados, em substituição ao tampão fosfato, $0,5 \mathrm{~mL}$ da mistura S9 (fração pós-mitocondrial, suplementada com um cofator, preparada a partir de fígado de roedores tratados com agentes indutores de enzimas, arocloror 1254). Decorrido o tempo de incubação, $2 \mathrm{~mL}$ de "top ágar”, contendo traços de L-histidina e D-biotina, foram adicionados a mistura presente nos tubos.

O conteúdo de cada tubo, assim composto, foi levemente homogeneizado em vórtex e vertido sobre a superfície de uma placa contendo ágar mínimo glicosado. Após solidificação do "top-ágar", as placas foram incubadas por $48 \mathrm{hrs,} \mathrm{a} 37^{\circ} \mathrm{C}$. Ao término 
desse período, foi realizada a contagem do número de colônias revertentes por placa. Os ensaios foram realizados em triplicata.

O controle negativo foi realizado com DMSO, e o controle positivo, para confirmar as propriedades de reversão e especificidade de cada cepa, foi usado Mitomicina, para linhagem TA102 na ausência de S9 e 2-aminofluoreno na presença de S9 e, já para linhagem TA98 foi usado 4-Nitrofenilenodiamina (NPD) na ausência de S9 e 2-antramino na presença de S9.

A partir dos resultados obtidos, foi calculada a razão de mutagenicidade (RM) para cada dose analisada, que é a média do número de revertentes na placa teste (espontâneos mais induzidos) dividido pela média do número de revertentes do controle negativo. A amostra foi considerada positiva quando a razão de mutagenicidade (RM) foi maior ou igual a dois em pelo menos uma das doses testadas e quando houve uma relação doseresposta entre as concentrações testadas e o número de revertentes induzidos (MORTELMANS E ZEIGER, 2000).

\subsubsection{Ensaio com Plasmídio pUC 9.1}

A linhagem bacteriana utilizada como hospedeira do plasmídeo pUC9.1 foi Escherichia coli DH5 $\alpha$ F'IQ, gentilmente cedida pelo Profo. Dr. José Carlos Pelielo de Mattos, da Universidade do Estado do Rio de Janeiro, Brasil. Esta linhagem bacteriana apresenta genótipo deficiente no gene rec e tem gene de resistência a canamicina (GUEDES et al., 2006). O DNA plasmidial pUC9.1, de 2695 pares de bases, apresenta resistência genética a ampicilina (SAMBROOK et al., 1989).

Com auxílio de alça de inoculação, uma pequena quantidade da cultura estoque congelada foi semeada, por esgotamento, em meio de cultura Luria Broth (meio LB) sólido, com ampicilina a $50 \mu \mathrm{g} / \mathrm{mL}$ e canamicina a $10 \mu \mathrm{g} / \mathrm{mL}$, e incubada overnight, a 
$37^{\circ} \mathrm{C}$, de modo a obter colônias isoladas. Uma dessas colônias foi selecionada e com auxílio de cabo de inoculação foi repicada em meio LB líquido, com a mesma concentração de antibióticos existente no meio sólido, incubada a $37^{\circ} \mathrm{C}$, por $16-18$ horas, com agitação (160 rpm), a fim de obter culturas na fase estacionária de crescimento.

O DNA plasmidial pUC9.1 foi extraído pelo método de lise alcalina, como descrito por Sambrook et al. (1989), utilizando kit para extração plasmidial da Fermentas Life Sciences (\#K0503 GeneJET Plasmid Miniprep Kit). O DNA obtido foi quantificado em espectrofotômetro de luz ultravioleta, com leitura em comprimento de onda de 260nm (uma unidade de densidade ótica, em 260nm, corresponde a $50 \mu \mathrm{g} / \mathrm{mL}$ DNA). Alíquotas (5 $\mu \mathrm{L})$ do DNA plasmidial obtido foram tratadas com concentrações crescentes dos compostos, ligantes e cis-platina $(0,5-20,0 \mu \mathrm{M})$ num volume de reação de $50 \mu \mathrm{L}$, completos com DMSO. As reações foram incubadas a $37^{\circ} \mathrm{C}$, por 1 hora e, ao final desse tempo, $10 \mu \mathrm{L}$ de cada amostra $(100 \mathrm{ng})$ foram misturadas com $3 \mu \mathrm{L}$ de tampão de carreamento e aplicadas em gel de agarose a 0,8\%. O gel foi submetido à eletroforese em cuba horizontal, em tampão TBE, com voltagem de $6 \mathrm{~V} / \mathrm{cm}$, por, aproximadamente, duas horas, até que ocorresse a separação das bandas. O gel foi corado com banho de brometo de etídeo $(0,5 \mu \mathrm{g} / \mathrm{mL})$, examinado e fotografado através de luz ultravioleta, em um sistema de transiluminação. As imagens dos géis foram obtidas usando o equipamento AlphaImager, da AlphaInotech, gentilmente cedido pelo laboratório de micobacteriologia Prof. Dr. Hugo David, da Faculdade de Ciências Farmacêuticas da UNESP, sob coordenação da Profa. Dr. Clarice Queico Leite.

O controle negativo foi feito com DMSO e o controle positivo foi feito com cloreto de estanho, que é capaz de modificar a estrutura conformacional do DNA plasmidial (conformação superhelicoidizada é convertida na conformação circular aberta), como demonstrado por Mattos et al. (2000). 
A análise densitométrica de cada conformação do DNA plasmidial foi feita com o auxílio do programa AlphaEase FC, da AlphaInotech, também gentilmente cedido pelo laboratório de micobacteriologia Profo. Dr. Hugo David, da Faculdade de Ciências Farmacêuticas da UNESP, sob coordenação da Profa. Dr. Clarice Queico Leite, através da função SpotDenso, das ferramentas de análises, que verifica a relação entre a quantidade de pixels e a área pré-estabelecida das bandas de cada conformação do DNA superhelicoidizada, circular aberta e linear - em cada concentração das amostras e nos controles, levando em consideração um padrão de massa de DNA fornecido.

A análise dos dados densitométricos fornece a percentagem de eventos nulos (ausência de quebras), para cada uma das concentrações testadas, com cada amostra.

Usando a distribuição de Poisson, foi obtido o valor médio de quebras para cada um dos tratamentos, a partir das percentagens das conformações de DNA superhelicoidizado, como segue: $\mu=-\ln p(0 ; \mu)$ (REMINGTON E SCHOR, 1985).

\subsection{Análise Estatística}

\subsubsection{Testes Imunológicos}

A análise estatística foi realizada utilizando o programa estatístico Graph Pad Instat aplicando-se análise de variância com determinação do nível de significância a 5\% através de comparações múltiplas pelo teste de Tukey.

\subsubsection{Teste de Ames}

Os dados de mutagenicidade foram analisados utilizando o programa estatístico Salanal elaborado e gentilmente cedido pelo Dr. L. Myers do Research Triangle Institute, RTP, Carolina do Norte, USA, por intermédio da Dra. Maria Ines Sato (CETESB). Esse programa permite avaliar o efeito dose-resposta através do cálculo da 
análise de variância (ANOVA - teste F) entre as médias do número de revertentes nas diferentes doses testadas e o controle negativo, seguido de uma regressão linear.

\subsubsection{Ensaio com Plasmídio pUC9.1}

A significância estatística do número de quebras por genoma fornecido pela distribuição de Poisson foi verificada por análise de variância (ANOVA - fator único) entre o número médio de quebras por genoma induzido pelas diferentes concentrações, de cada amostra, e o controle negativo, ao nível de 5\% de significância $(\mathrm{p}=0,05)$. 


\section{RESULTADOS}

5.1 Avaliação da citotoxicidade de macrófagos peritoneais e células tumorais de Ehrlich pela técnica de MTT (MOSSMAN, 1983)

Os ensaios para determinação da citotoxicidade demonstraram que os macrófagos obtidos de animais não portadores e animais portadores do tumor de Ehrlich na sua forma sólida assim como a célula tumoral de Ehrlich, são sensíveis ao potencial tóxico dos compostos, assim como, ao da droga padrão, quando incubados por $24 \mathrm{~h}$.

A atividade citotóxica dos ligantes dmba, tu e dos complexos de paládio (II) assim como a cis-platina para macrófagos peritoneais estão apresentados na Tabela 1. Observou-se que para os animais normais o ligante tu apresentou um maior potencial citotóxico. Já nos animais portadores do tumor na sua forma sólida a cis-platina foi quem apresentou maior potencial citotóxico.

A Tabela 2 apresenta a atividade citotóxica dos ligantes dmba, tu e dos complexos de paládio (II) assim como a cis-platina para célula tumoral de Ehrlich. Foi observado que o ligante tu foi quem apresentou um maior potencial citotóxico, seguido pelo ligante dmba, e os compostos 1 e 2.

Após a definição do índice de citotoxicidade mediano $\left(\mathrm{IC}_{50}\right)$ para animais portadores e não portadores de tumor de Ehrlich, utilizou-se estes valores para realização dos testes propostos no estudo. 
Tabela 1 - Valores de $\mathrm{IC}_{50}$ dos compostos para as células aderentes peritoneais de camundongos normais e portadores do tumor sólido de Ehrlich após 24 de exposição

\begin{tabular}{|c|c|c|}
\hline Compostos & $\begin{array}{l}\text { Animal não portador } \\
\text { IC } 50^{1,2}\end{array}$ & $\begin{array}{c}\text { Animal portador } \\
\text { IC50 }\end{array}$ \\
\hline$[\operatorname{Pd}(\operatorname{dmba})(\mathrm{Cl}) \mathrm{tu}]$ & $131,65 \pm 1,89$ & $137,65 \pm 0,22$ \\
\hline$\left[\operatorname{Pd}(\mathbf{d m b a})\left(\mathrm{N}_{3}\right) \mathrm{tu}\right]$ & $99,04 \pm 3,47$ & $137,65 \pm 2,67$ \\
\hline dmba & $13,59 \pm 0,8$ & $462,80 \pm 0,48$ \\
\hline $\mathbf{T u}$ & $10,01 \pm 0,7$ & $612,93 \pm 0,23$ \\
\hline Cis-Pt & $71,69 \pm 2,15$ & $113,21 \pm 0,28$ \\
\hline
\end{tabular}

${ }^{1-} 5 \times 10^{6}$ células / cavidade.

${ }^{2-}$ Os valores acima são dados como média \pm DP de cinco animais em triplicata, valores determinados por uma curva dose-resposta, expressos em $\mu \mathrm{M}$.

Tabela 2 - Valores de $\mathrm{IC}_{50}$ dos compostos para as células tumorais de Erlich após 24 horas de exposição

\begin{tabular}{lc}
\hline $\mathbf{I C 5 0}^{\mathbf{1 , 2}}$ & Célula Tumoral de Ehrlich \\
\hline$[\mathbf{P d}(\mathbf{d m b a})(\mathbf{C l}) \mathbf{t u}]$ & $72,80 \pm 3,23$ \\
{$\left[\mathbf{P d}(\mathbf{d m b a})\left(\mathbf{N}_{\mathbf{3}}\right) \mathbf{t u}\right]$} & $39,70 \pm 0,30$ \\
$\mathbf{d m b a}$ & $15,59 \pm 1,35$ \\
tu & $10,98 \pm 3,4$ \\
Cis-Pt & $40,28 \pm 2,97$ \\
\hline
\end{tabular}

1- $5 \times 10^{6}$ células / cavidade.

${ }^{2-}$ Os valores acima são dados como média \pm DP de cinco animais em triplicata, valores determinados por uma curva dose-resposta, expressos em $\mu \mathrm{M}$. 


\subsection{Determinação da produção de Peróxido de Hidrogênio $\left(\mathrm{H}_{2} \mathrm{O}_{2}\right)$}

Os compostos $1[\mathrm{Pd}(\mathrm{dmba})(\mathrm{Cl}) \mathrm{tu}], 2[\mathrm{Pd}(\mathrm{dmba})(\mathrm{N} 3) \mathrm{tu}], \mathrm{dmba}$, Tu e cis-platina quando em contato com as células do exsudato peritoneal de animais não portadores de tumor, produziram níveis significativos de $\mathrm{H}_{2} \mathrm{O}_{2}$ em relação ao controle negativo (p<0,001) (Fig. 3 A). Já nos animais do tumor de Erlich na sua forma sólida, observouse uma produção de peróxido de hidrogênio apenas pelo ligante tu $(\mathrm{p}<0,05)$ (Fig. $3 \mathrm{~B})$. Em ambos os casos, não houve uma diferença significativa dos compostos em relação a droga padrão (cis-platina). 
A)

\section{IC 50}

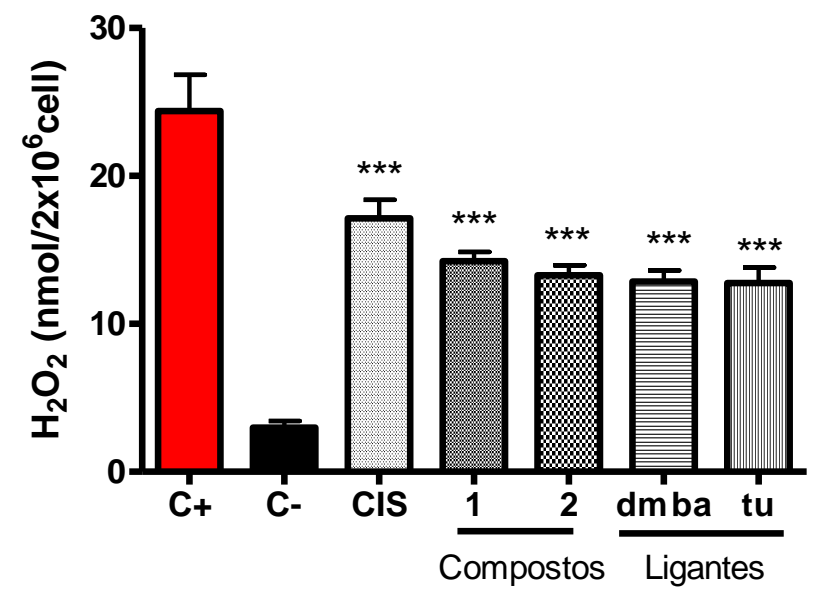

B)

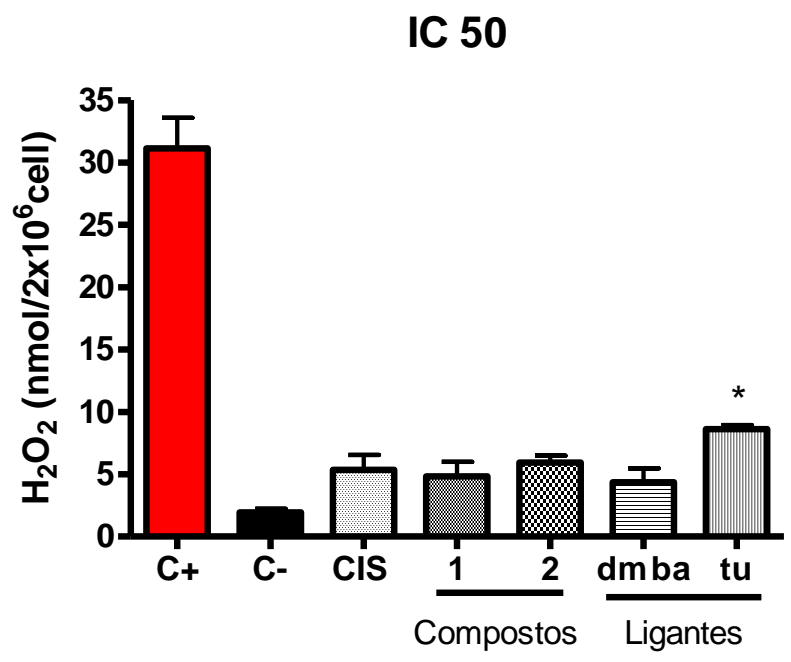

Fig 3. Produção de peróxido de hidrogênio em culturas de células peritoneais aderentes. As células aderentes de animais não portadores (A) e portadores do tumor sólido de Ehrlich (B) foram incubadas com os compostos e a cis-Pt por $24 \mathrm{~h}$ de incubação em estufa de $\mathrm{CO}_{2}$ a $37^{\circ} \mathrm{C}$. Foi utilizado RPMI-1640-C (controle negativo, C-) e PMA (controle positivo, C+). As concentrações de $\mathrm{H}_{2} \mathrm{O}_{2}$ foram expressas em nanomols de $\mathrm{H}_{2} \mathrm{O}_{2} / 2 \times 10^{5}$ células, como a média \pm desvio-padrão de triplicatas de 5 animais.

$* * * \mathrm{p}<0,001$ quando comparado ao controle negativo.

$* \mathrm{p}<0,05$ quando comparado ao controle negativo. 


\subsection{Determinação da produção de Óxido Nítrico (NO)}

No exudato peritoneal de animais não portadores de tumor, o ligante dmba foi quem apresentou uma maior produção de NO quando comparado com o controle negativo $(\mathrm{p}<0,01)$, ressaltando que houve uma diferença significatica da produção de NO pelo ligante quando este foi comparado a cis-platina $(\mathrm{p}<0,001)$ (Fig. 4 A). Por outro lado nos animais portadores do tumor de Ehrlich o composto 2 foi quem apresentou maior produção de NO $(\mathrm{p}<0.001)$, seguido pela cis-pt e os ligantes dmba, tu $(\mathrm{p}<0,001)$ (Fig. 4 B). 
A)

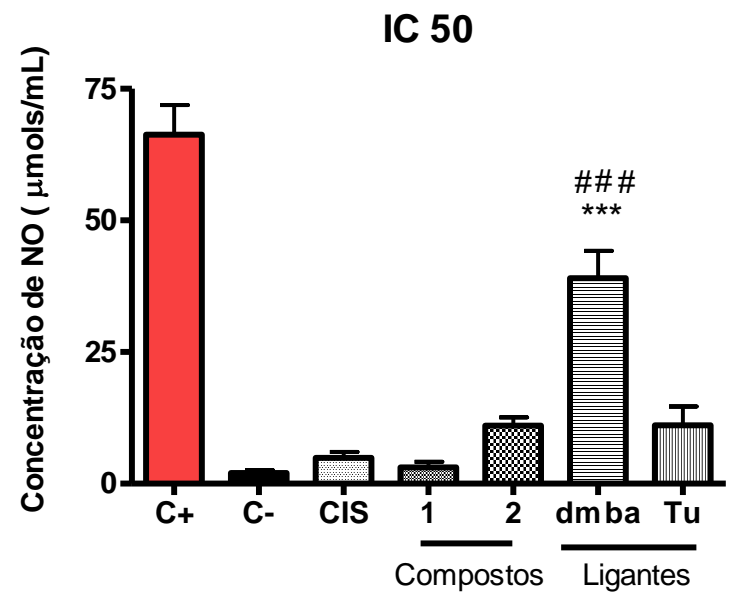

B)

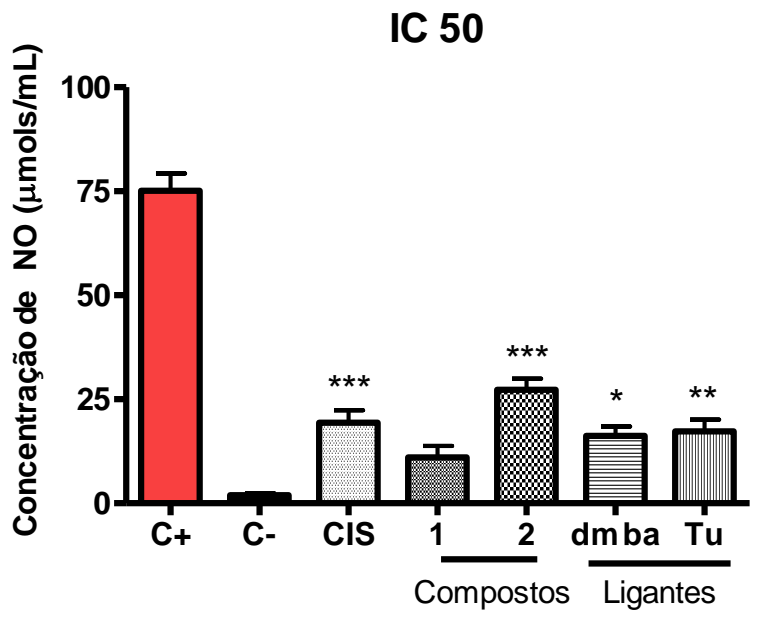

Fig 4. Produção de óxido nítrico em culturas de células peritoneais aderentes As células aderentes de animais não portadores (A) e portadores do tumor sólido de Ehrlich (B) foram incubadas com os compostos e a cis-Pt por $24 \mathrm{~h}$ de incubação em estufa de $\mathrm{CO}_{2}$ a $37^{\circ} \mathrm{C}$. Foi utilizado RPMI-1640-C (controle negativo, C-) e LPS (controle positivo, C+). As concentrações de NO liberadas foram calculadas a partir de uma curva padrão previamente estabelecida com concentrações molares conhecidas de nitrito de sódio em meio RPMI-1640. Os resultados foram expressos como a média \pm desvio-padrão de triplicatas de 5 animais.

$* * * \mathrm{p}<0,001$ quando comparado ao controle negativo.

$* * \mathrm{p}<0,01$ quando comparado ao controle negativo.

${ }^{*} \mathrm{p}<0,05$ quando comparado ao controle negativo.

\#\#\# p<0,001 quando comparado à cis-Pt. 


\subsection{Determinação da citocina TNF- $\alpha$ nos sobrenadantes das culturas de células}

aderentes

Nos macrófagos peritoneais murinos de animais não portadores de tumor, o composto 1,2 , ligante dmba e cis-platina demosntratam uma maior produção de TNF- $\alpha$ ( $\mathrm{p}<0,001)$ quando comparado com o controle negativo(Fig. 5 A). Enquanto nos animais portadores do tumor de Ehrlich o composto 2 foi quem apresentou maior produção ( $\mathrm{p}<0,001)$ seguido do composto 1 , cis-platina $(\mathrm{p}<0,01)$ e ligante tu $(\mathrm{p}<0,05)$, ressaltando que houve uma diferença significativa da produção de TNF- $\alpha$ do composto 2 quando comparado com a cis-platina $(\mathrm{p}<0,05)$ (Fig. 5 B). 
A)

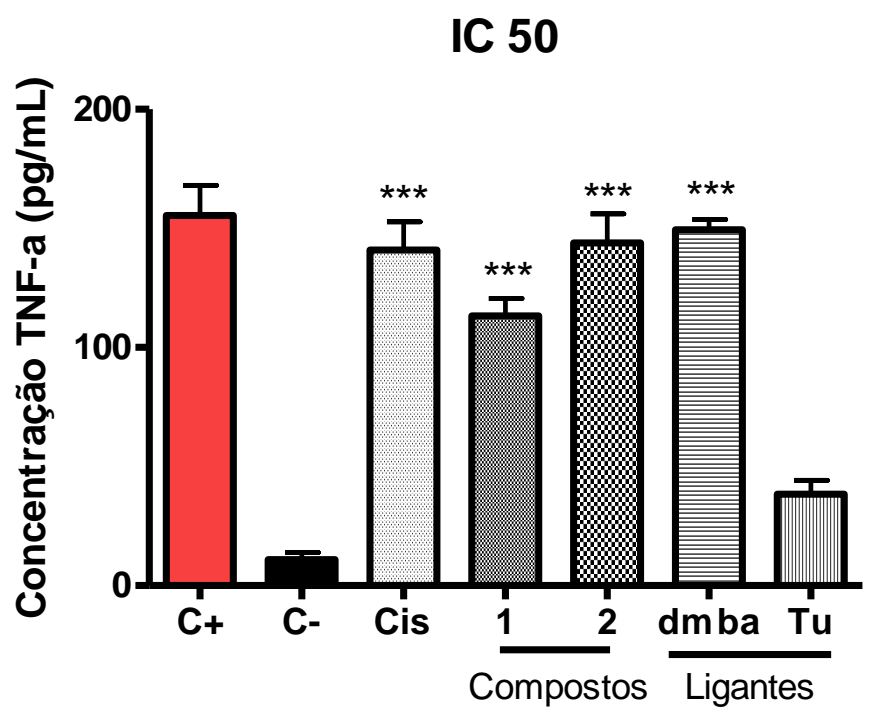

B)

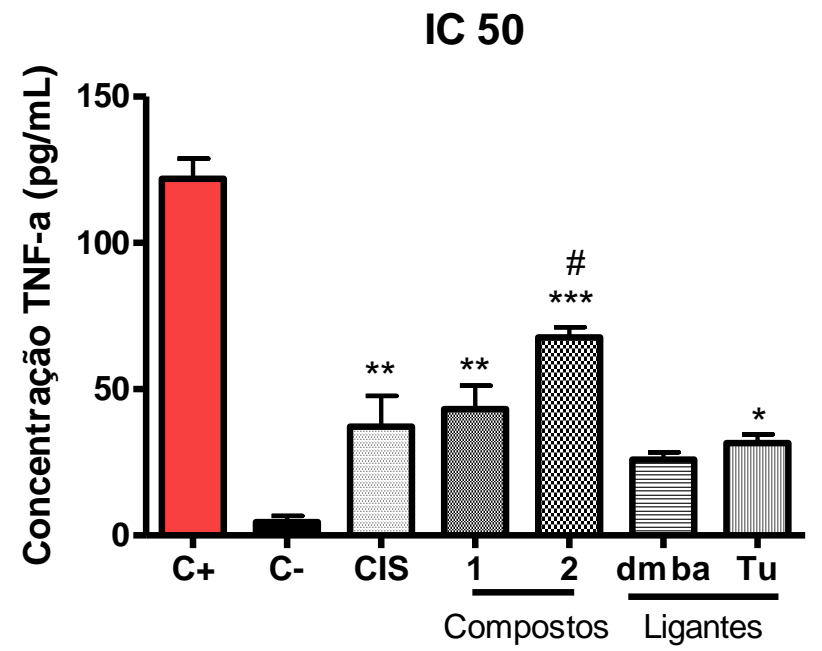

Fig 5. Produção de TNF- $\alpha$ nos sobrenadantes das culturas de células aderentes. As células aderentes de animais não portadores (A) e portadores do tumor sólido de Ehrlich (B) foram incubadas com os compostos e a cis-Pt por $24 \mathrm{~h}$ de incubação em estufa de $\mathrm{CO}_{2}$ a $37^{\circ} \mathrm{C}$. Foi utilizado RPMI-1640-C (controle negativo, C-) e LPS (controle positivo, C+). A determinação desta citocina foi realizada através do ensaio de ELISA. As concentrações de TNF- $\alpha$ foram calculadas através de uma reta padrão previamente estabelecida com concentrações molares conhecidas de TNF- $\alpha$. Os resultados foram expressos como a média \pm desvio-padrão de triplicatas de 5 animais.

$* * * \mathrm{p}<0,001$ quando comparado ao controle negativo.

$* * p<0,01$ quando comparado ao controle negativo.

$* p<0,05$ quando comparado ao controle negativo.

\# $\mathrm{p}<0,05$ quando comparado à cis-PT. 


\subsection{Determinação da citocina IL-1ß nos sobrenadantes das culturas de células}

aderentes

Nos macrófagos peritoneais murinos normais o composto 2 e o ligante dmba $(\mathrm{p}<0,001)$, seguido pelo ligante tu $(\mathrm{p}<0,01)$ apresentaram uma produção de níveis significativos de IL-1 $\beta$ em relação ao controle negativo, ressaltando que houve uma diferença significativa da produção de IL-1 $\beta$, pelo composto 2 e ligante dmba quando comparados com a cis-platina $(\mathrm{p}<0,01)$ (Fig. 6 A). Naqueles portadores do tumor de Ehrlich, os compostos, ligantes e cis-platina não foram capazes de induzir a produção desta citocina (Fig. 6 B). 
A)

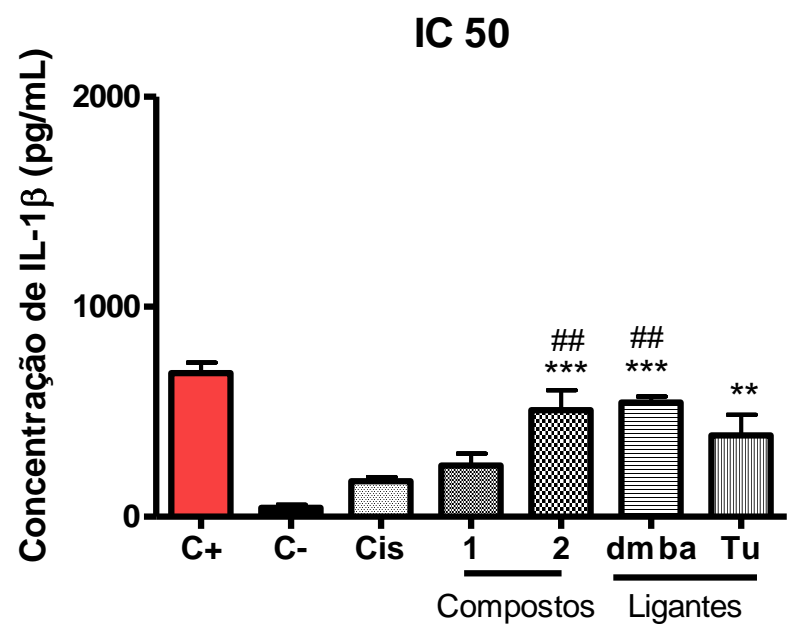

B)

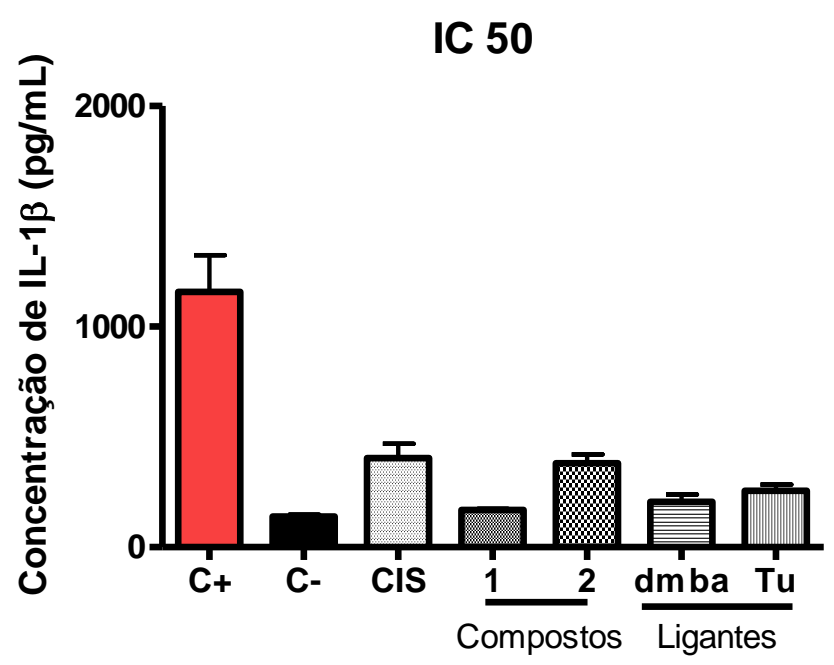

Fig 6. Produção de interleucina-1ß nos sobrenadantes das culturas de células aderentes. As células aderentes de animais não portadores (A) e portadores do tumor sólido de Ehrlich (B) foram incubadas com os compostos e a cis-Pt por $24 \mathrm{~h}$ de incubação em estufa de $\mathrm{CO}_{2}$ a $37^{\circ} \mathrm{C}$. Foi utilizado RPMI-1640-C (controle negativo, C-) e LPS (controle positivo, C+). A determianção desta citocina foi realizado através do ensaio de ELISA. As concentrações de IL-1 $\beta$ foram calculadas através de uma reta padrão previamente estabelecida com concentrações molares conhecidas de IL-1 $\beta$. Os resultados foram expressos como a média \pm desvio-padrão de triplicatas de 5 animais.

$* * * \mathrm{p}<0,001$ quando comparado ao controle negativo.

$* * \mathrm{p}<0,01$ quando comparado ao controle negativo.

$* p<0,05$ quando comparado ao controle negativo.

\#\# p<0,01 quando comparado à cis-PT. 


\subsection{Determinação da citocina IL-6 nos sobrenadantes das culturas de células}

\section{aderentes}

Nos macrófagos peritoneais murinos de animais não portadores de tumor, o composto $2(\mathrm{p}<0,001)$, seguido do composto 1 e do ligante dmba $(\mathrm{p}<0,01)$ apresentaram maior produção de IL-6, quando comparado com o controle negativo, ressaltando que houve uma diferença significativa da produção de IL-6, pelo composto 2 quando comparados com a cis-platina $(\mathrm{p}<0,01)$ (Fig. 7 A). Já aqueles portadores do tumor de Erlich na sua forma sólida, o composto 1, composto 2, ligante dmba e cis-platina foram quem apresentaram a maior produção desta citocina $(\mathrm{p}<0,001)$ seguido pelo ligante tu $(\mathrm{p}<0,01)($ Fig. 7 B). 
A)

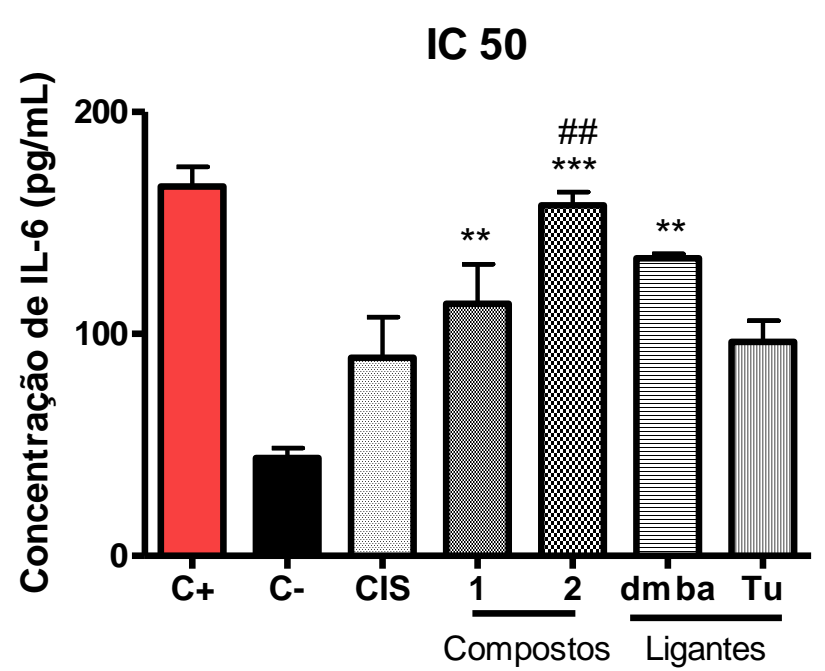

B)

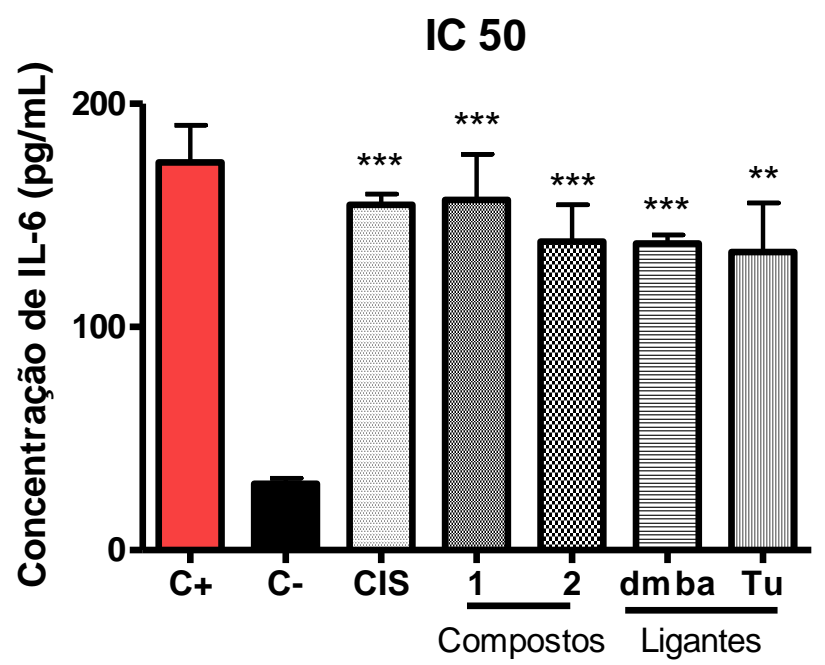

Fig 7. Produção de IL-6 nos sobrenadantes das culturas de células aderentes. As células aderentes de animais não portadores (A) e portadores do tumor sólido de Ehrlich (B) foram incubadas com os compostos e a cis-Pt por $24 \mathrm{~h}$ de incubação em estufa de $\mathrm{CO}_{2}$ a $37^{\circ} \mathrm{C}$. Foi utilizado RPMI-1640-C (controle negativo, C-) e LPS (controle positivo, C+). A determianção desta citocina foi realizado através do ensaio de ELISA. As concentrações de IL-6 foram calculadas através de uma reta padrão previamente estabelecida com concentrações molares conhecidas de IL-6. Os resultados foram expressos como a média \pm desvio-padrão de triplicatas de 5 animais.

$* * * \mathrm{p}<0,001$ quando comparado ao controle negativo.

$* * \mathrm{p}<0,01$ quando comparado ao controle negativo.

${ }^{*} \mathrm{p}<0,05$ quando comparado ao controle negativo.

\#\# $\mathrm{p}<0,01$ quando comparado à cis-PT. 


\subsection{Determinação da citocina IL-12 nos sobrenadantes das culturas de células}

\section{aderentes}

Nos macrófagos peritoneais murinos de animais não portadores de tumor os

compostos 1, 2 e liagnte dmba $(\mathrm{p}<0,001)$ seguidos pela cis-platina $(\mathrm{p}<0,01)$, demontratam uma maior produção desta citocina em relação ao controle negativo, ressaltando que houve uma diferença significativa da produção de IL-12 pelo composto 2 quando comparado com a cis-platina $(\mathrm{p}<0,01)$ (Fig. 8 A). Nos animais portadores do tumor de Ehrlich, o ligante dmba demonstrou uma maior produção desta citocina $(\mathrm{p}<0,01)$ seguidos pelo composto 2, ligante tu e cis-Pt $(\mathrm{p}<0,05)$ (Fig. 8 B). 
A)

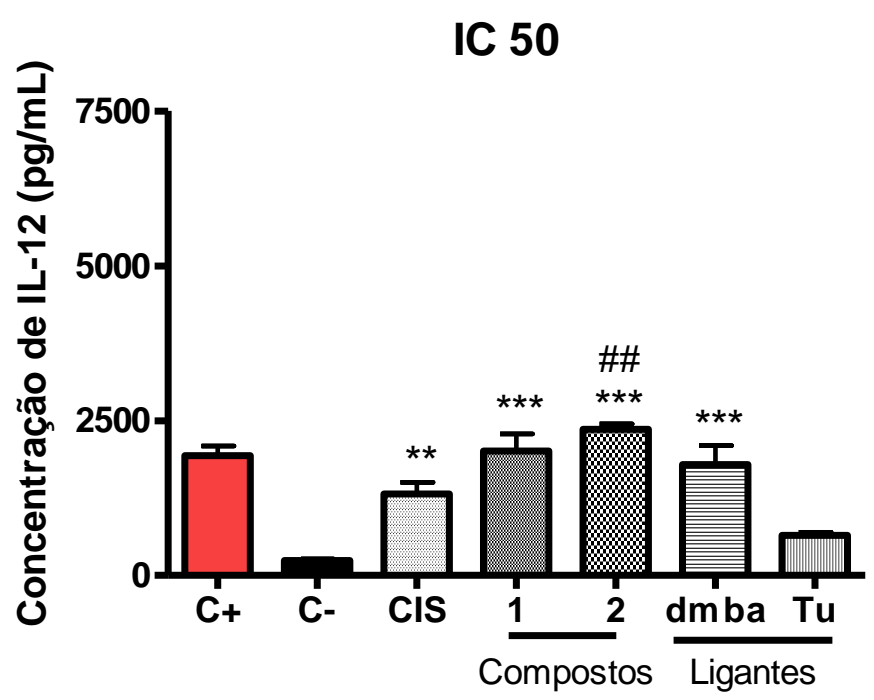

B)

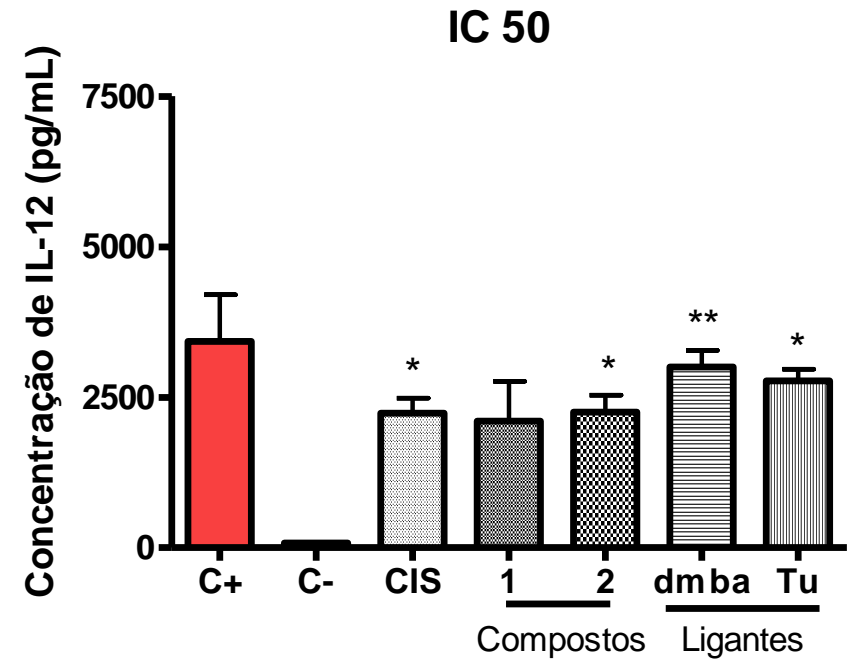

Fig 8. Produção de IL-12 nos sobrenadantes das culturas de células aderentes. As células aderentes de animais não portadores (A) e portadores do tumor sólido de Ehrlich (B) foram incubadas com os compostos e a cis-Pt por $24 \mathrm{~h}$ de incubação em estufa de $\mathrm{CO}_{2}$ a $37^{\circ} \mathrm{C}$. Foi utilizado RPMI-1640-C (controle negativo, C-) e LPS (controle positivo, C+). A determianção desta citocina foi realizado através do ensaio de ELISA. As concentrações de IL-12 foram calculadas através de uma reta padrão previamente estabelecida com concentrações molares conhecidas de IL-12. Os resultados foram expressos como a média \pm desvio-padrão de triplicatas de 5 animais.

$* * * \mathrm{p}<0,001$ quando comparado ao controle negativo.

$* * \mathrm{p}<0,01$ quando comparado ao controle negativo.

${ }^{*} \mathrm{p}<0,05$ quando comparado ao controle negativo.

\#\# p<0,01 quando comparado à cis-PT. 
5.8 Determinação da citocina IL-10 nos sobrenadantes das culturas de células aderentes

Os $\mathrm{IC}_{50}$ definidos para os compostos 1 [Pd(dmba)(Cl)tu], 2 [Pd(dmba) $\left.\left(\mathrm{N}_{3}\right) t u\right]$, dmba, Tu, demonstraram não produzir níveis significativos de IL-10 em relação ao controle negativo, pelos macrófagos peritoneais murinos de animais não portadores (Fig. 9 A) e aqueles portadores do tumor de Erlich na sua forma sólida (Fig. 9 B). 
A)

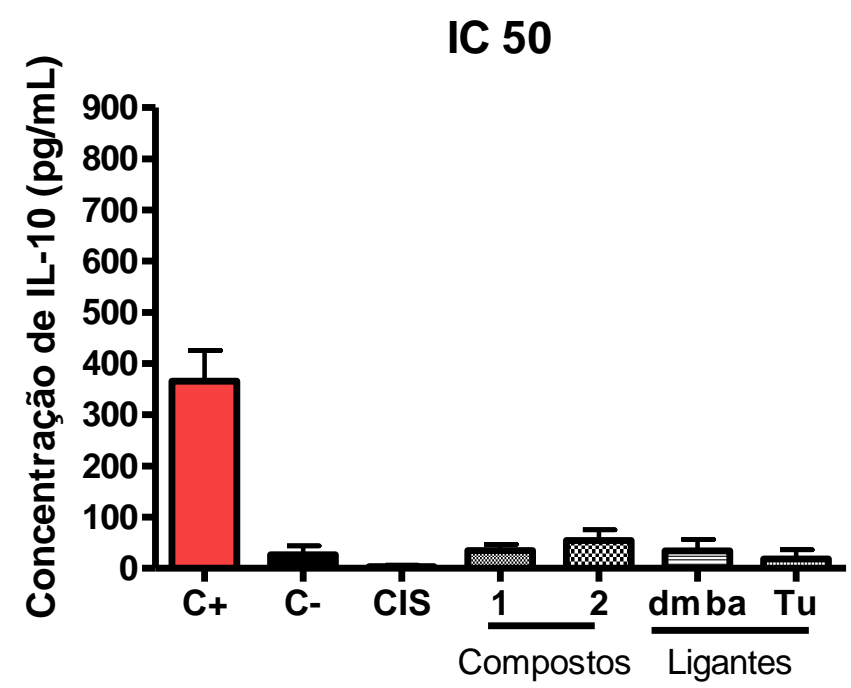

B)

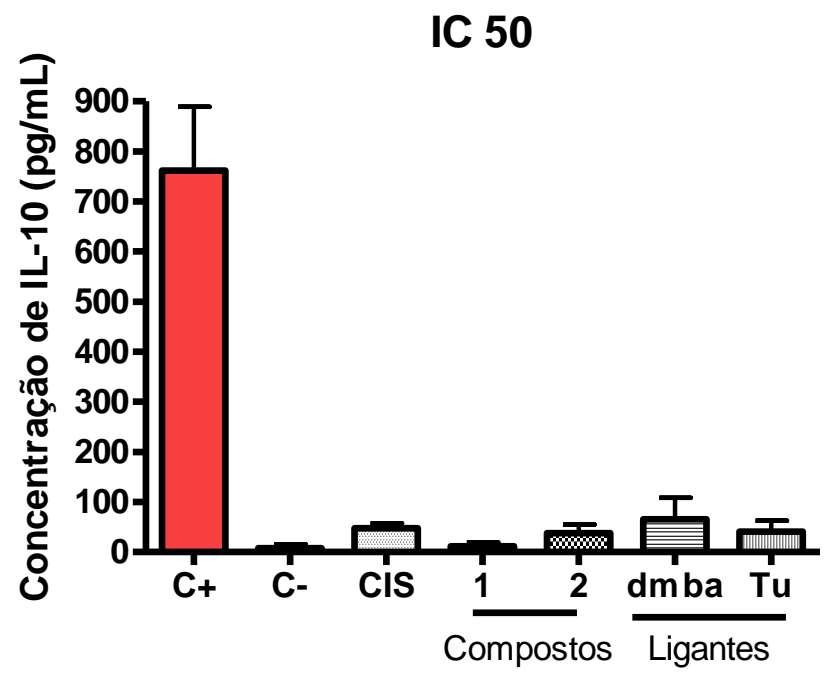

Fig 9. Produção de IL-10 nos sobrenadantes das culturas de células aderentes. As células aderentes de animais não portadores (A) e portadores do tumor sólido de Ehrlich (B) foram incubadas com os compostos e a cis-Pt por $24 \mathrm{~h}$ de incubação em estufa de $\mathrm{CO}_{2}$ a $37^{\circ} \mathrm{C}$. Foi utilizado RPMI-1640-C (controle negativo, C-) e LPS (controle positivo, C+). A determianção desta citocina foi realizado através do ensaio de ELISA. As concentrações de IL-10 foram calculadas através de uma reta padrão previamente estabelecida com concentrações molares conhecidas de IL-10. Os resultados foram expressos como a média \pm desvio-padrão de triplicatas de 5 animais. 
5.9 Determinação da mutagenicidade pelo Teste de Ames (Salmonella/Microsome Assay)

Nos ensaios de mutagenicidade não foram observados qualquer efeito mutagênico para ambas as linhagens (TA 102 e TA 98), com ou sem ativação metabólica, para os compostos: $1[\mathrm{Pd}(\mathrm{dmba})(\mathrm{Cl}) t \mathrm{tu}], 2\left[\mathrm{Pd}(\mathrm{dmba})\left(\mathrm{N}_{3}\right) \mathrm{tu}\right]$, e seus ligantes dmba e tu. Entretanto foi observada citotoxicidade para a cis-platina (Tabelas 3, 4, 5 e 6). Verifica-se que não houve aumento da freqüência normal de mutantes revertentes e os valores de RM ficaram todos abaixo de dois, com exceção da cisplatina que apresentou valores de RM que variaram de 2,05 a 2,08. 


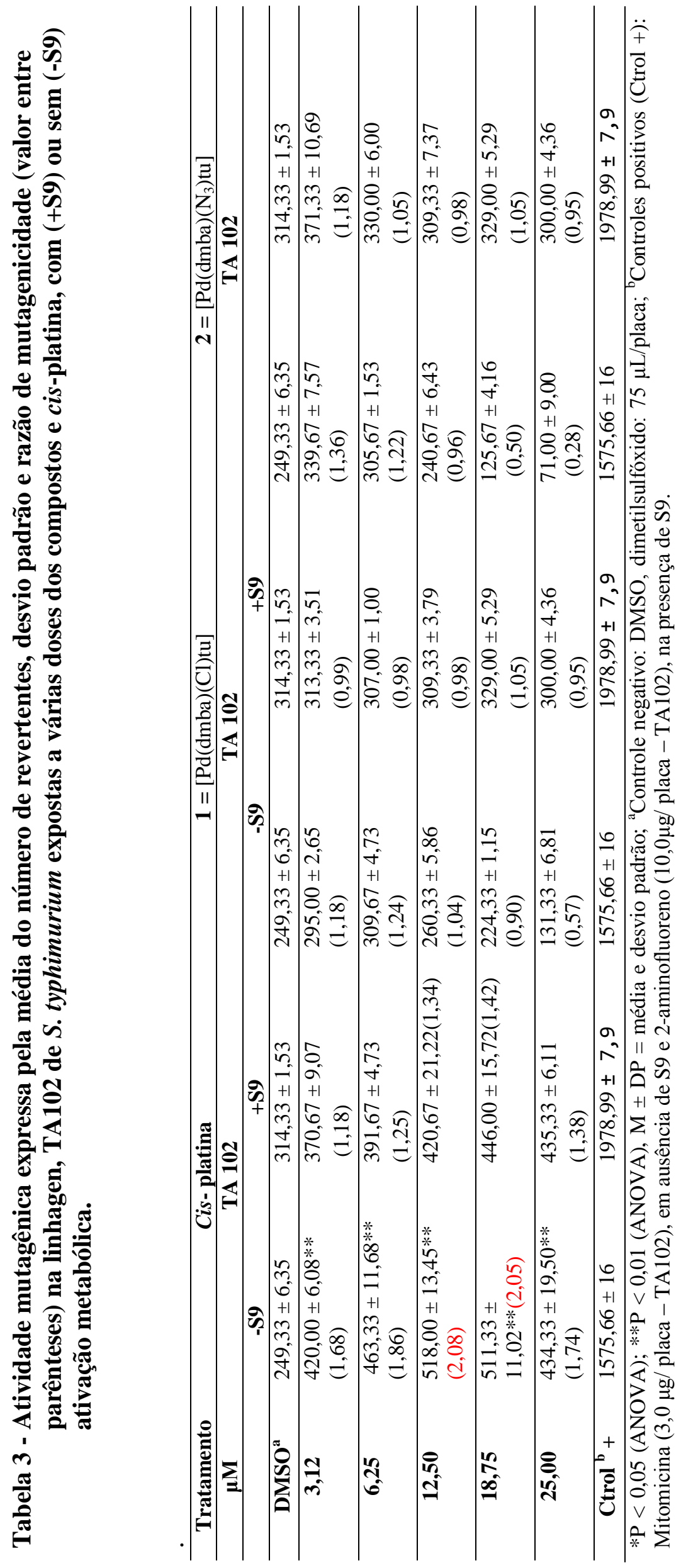




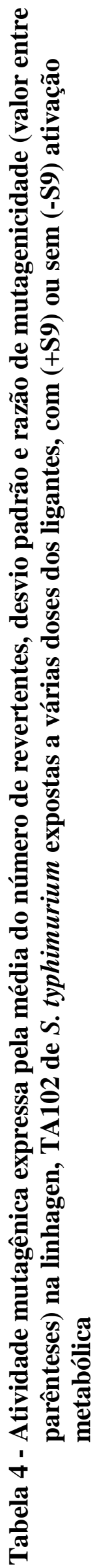

羊安至

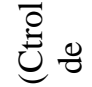

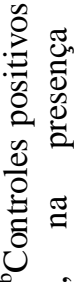

迎

三

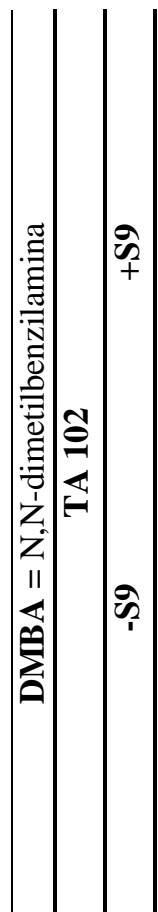

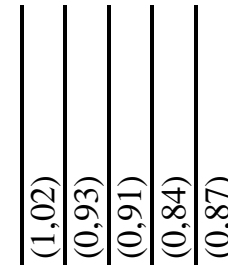

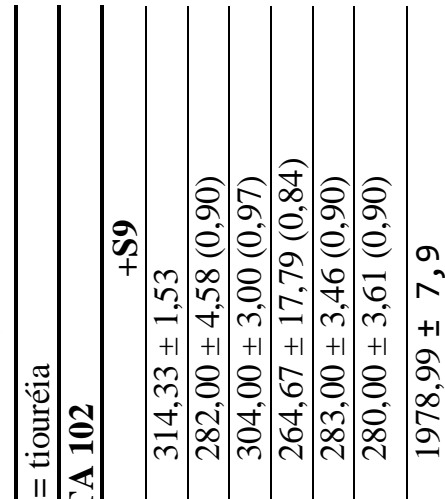

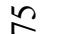

$\ddot{0} \frac{\pi}{0}$

兽

.

O̊

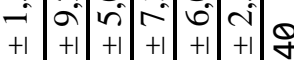

ले ले के के +1

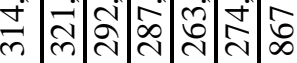

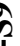

ㅇ․ ㅎ․ㅇ․․

을

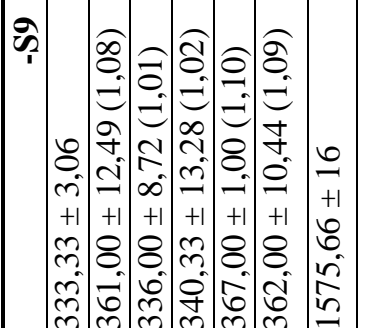

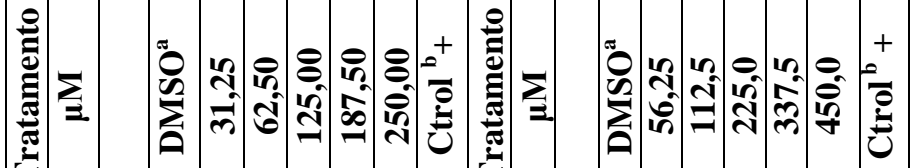

究

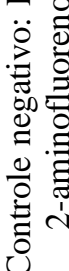

放的

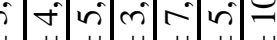

ले

ली

$\stackrel{\circ}{7} \frac{8}{8}$

过

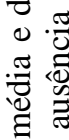

II

ลิ ซ

$+1$

过

更

这

횽

\%

*. b

${ }_{\overline{4}}^{20}$

安

ㅇ․류

* 

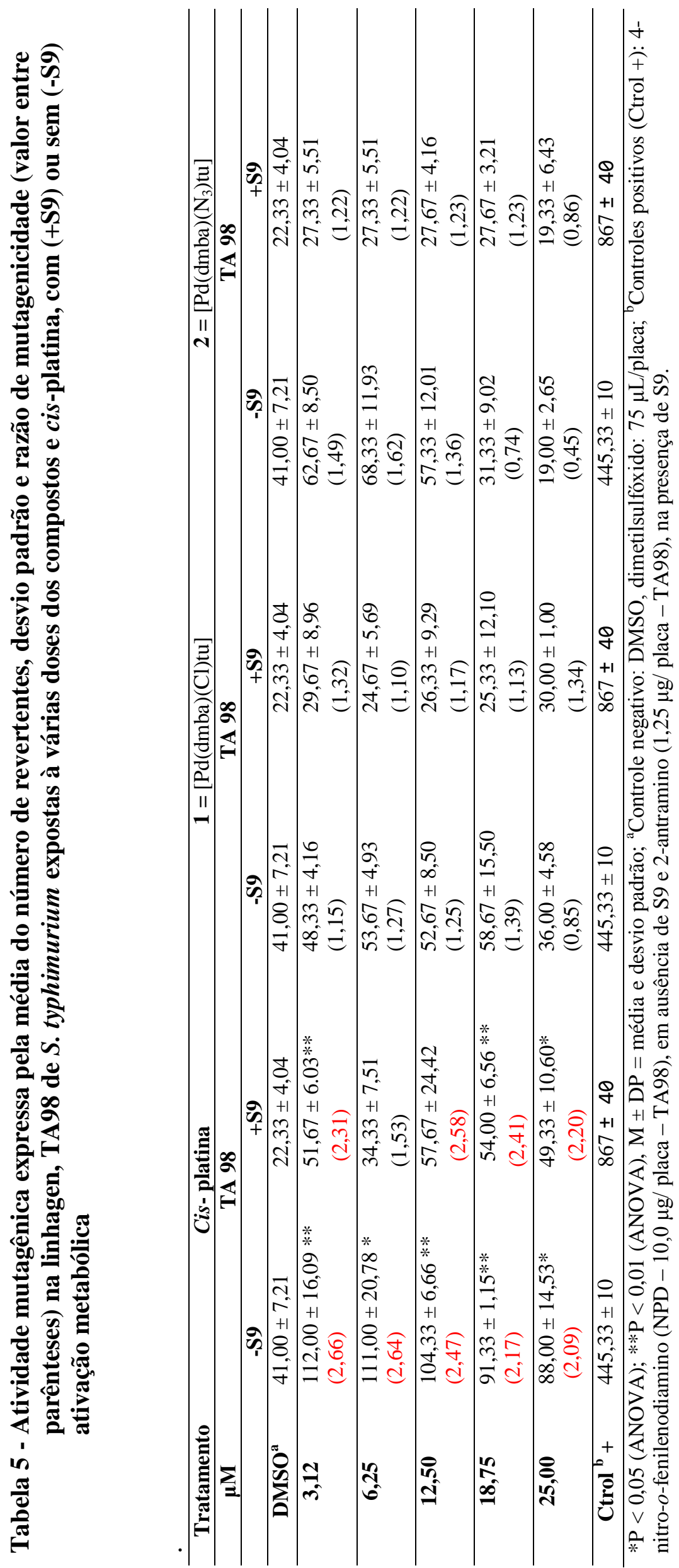


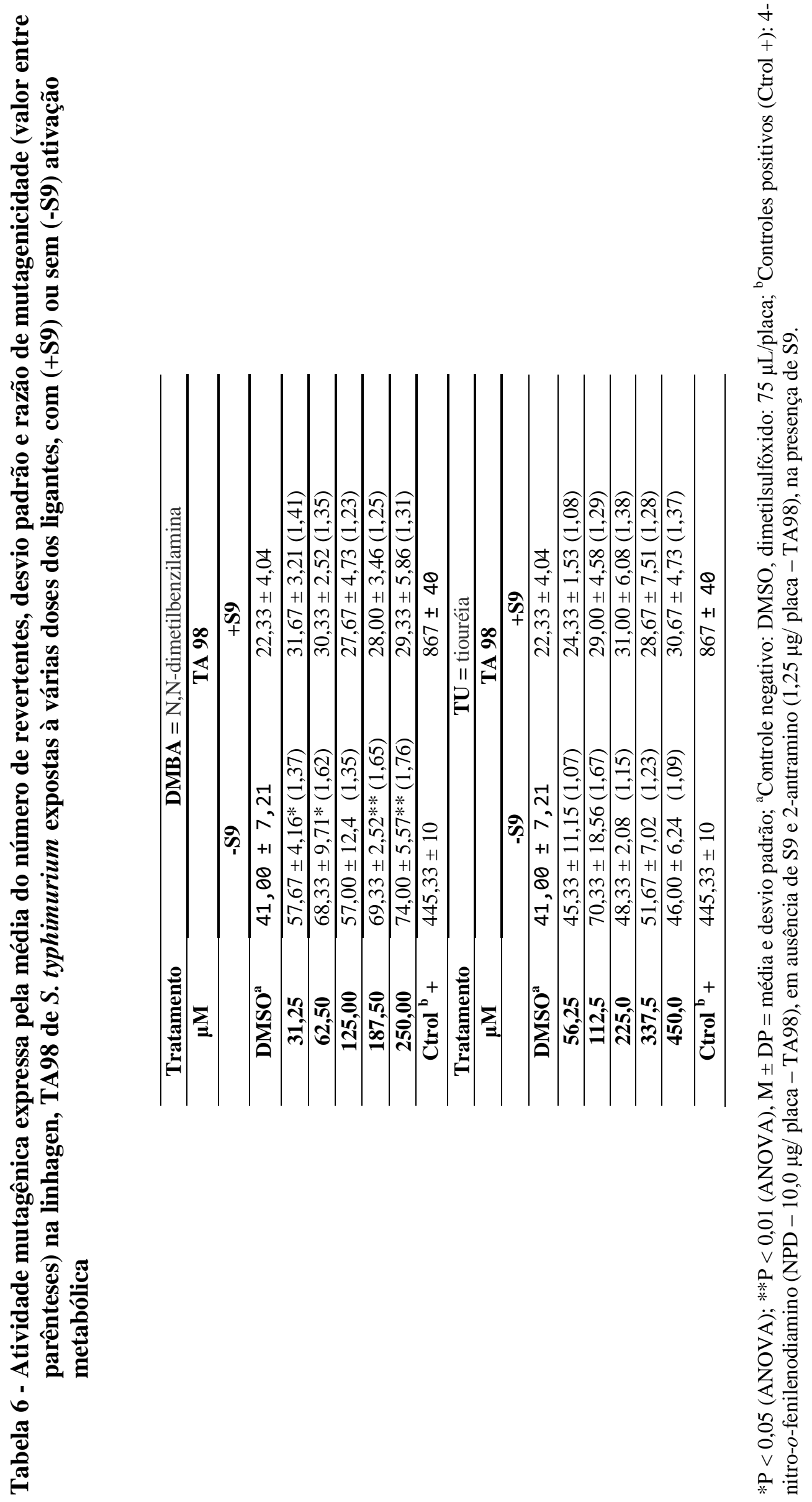




\subsection{Determinação da mutagenicidade pelo Teste com plasmídio pUC9.1}

Nos ensaios de genotoxicidade com plasmídio pUC 9.1 não foram observados qualquer indução de quebras nas fitas do mesmo, após os tratamentos do com os compostos 1 e 2, ligantes dmba e tu (Fig 10, 11, 12, 13) respectivamente. Porém, a droga usada como padrão de referência induziu grande quantidade de quebras em pequenos fragmentos, o que não ocasionou a formação de bandas e sim um característico arraste na corrida do gel (Fig. 14). 

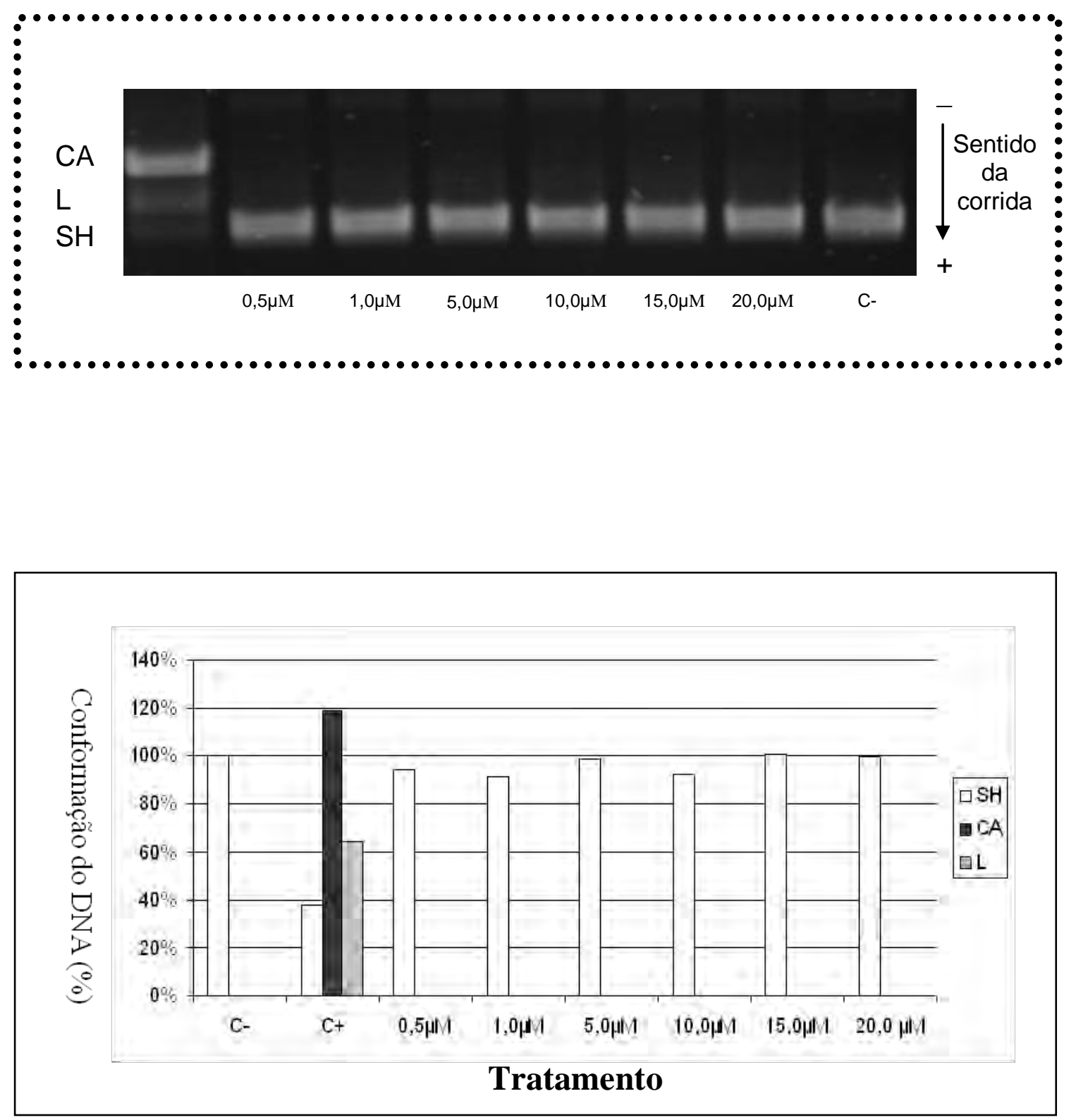

Figura 10. Eletroforese em gel de agarose a $0,8 \%$ e análise densitométrica das concentrações das conformações superhelicoidizada (SH), circular aberta (CA) e linear ( $\mathrm{L}$ ) do plasmídeo pUC9.1, após tratamento com 0 composto 1 [Pd(dmba) $(\mathbf{C l}) \mathbf{t u}]$. Controle - $(\mathrm{DMSO})$; Controle $+(200 \mu \mathrm{g} / \mathrm{mL}$ SnCl2- Cloreto de Estanho). 

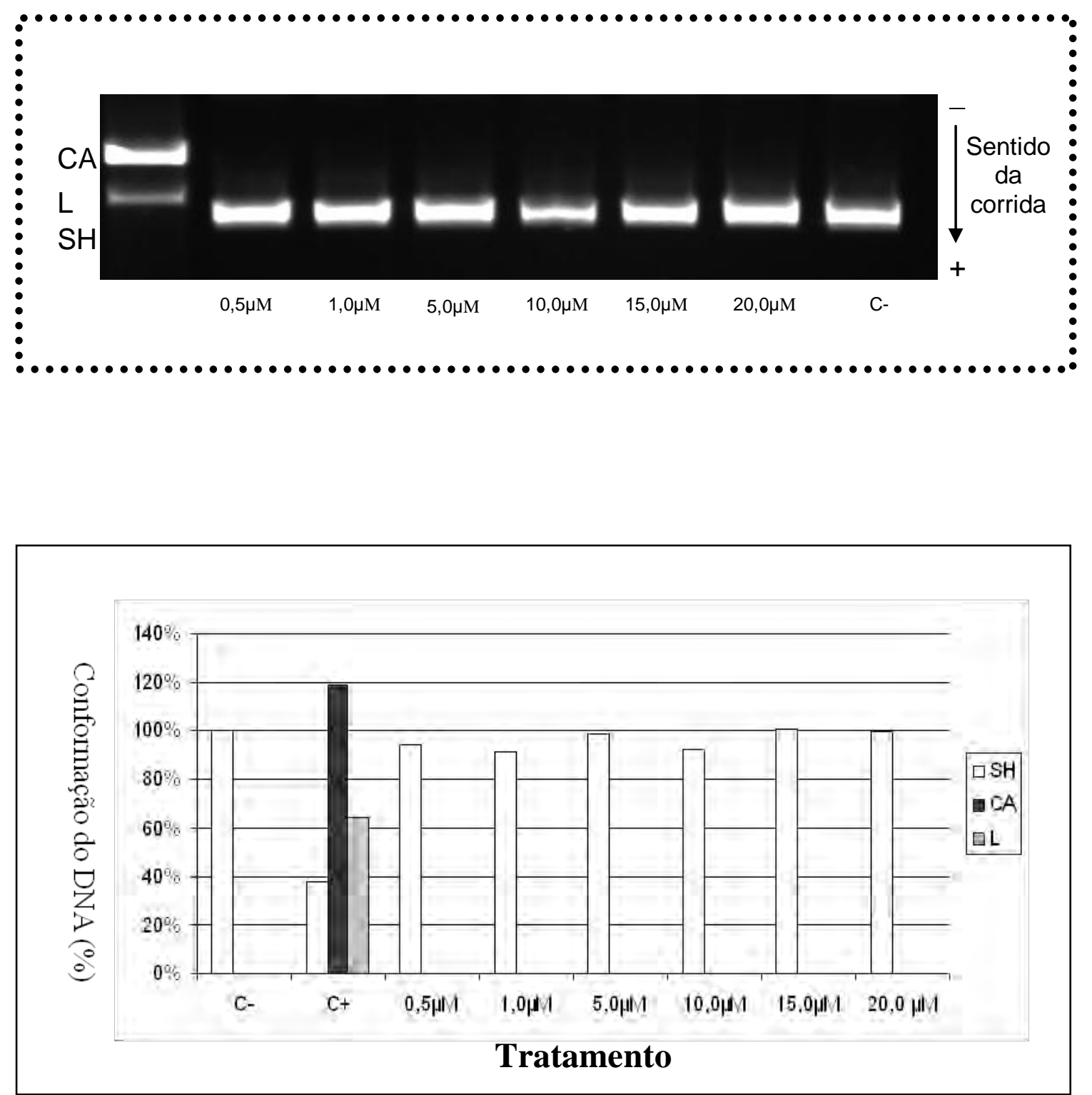

Figura 11. Eletroforese em gel de agarose a $0,8 \%$ e análise densitométrica das concentrações das conformações superhelicoidizada (SH), circular aberta (CA) e linear ( $\mathrm{L}$ ) do plasmídeo pUC9.1, após tratamento com o composto 2 $\left[\mathbf{P d}(\mathbf{d m b a})\left(\mathbf{N}_{3}\right) \mathbf{t u}\right]$. Controle - $(\mathrm{DMSO}) ;$ Controle $+(200 \mu \mathrm{g} / \mathrm{mL} \mathrm{SnCl} 2-$ Cloreto de Estanho). 

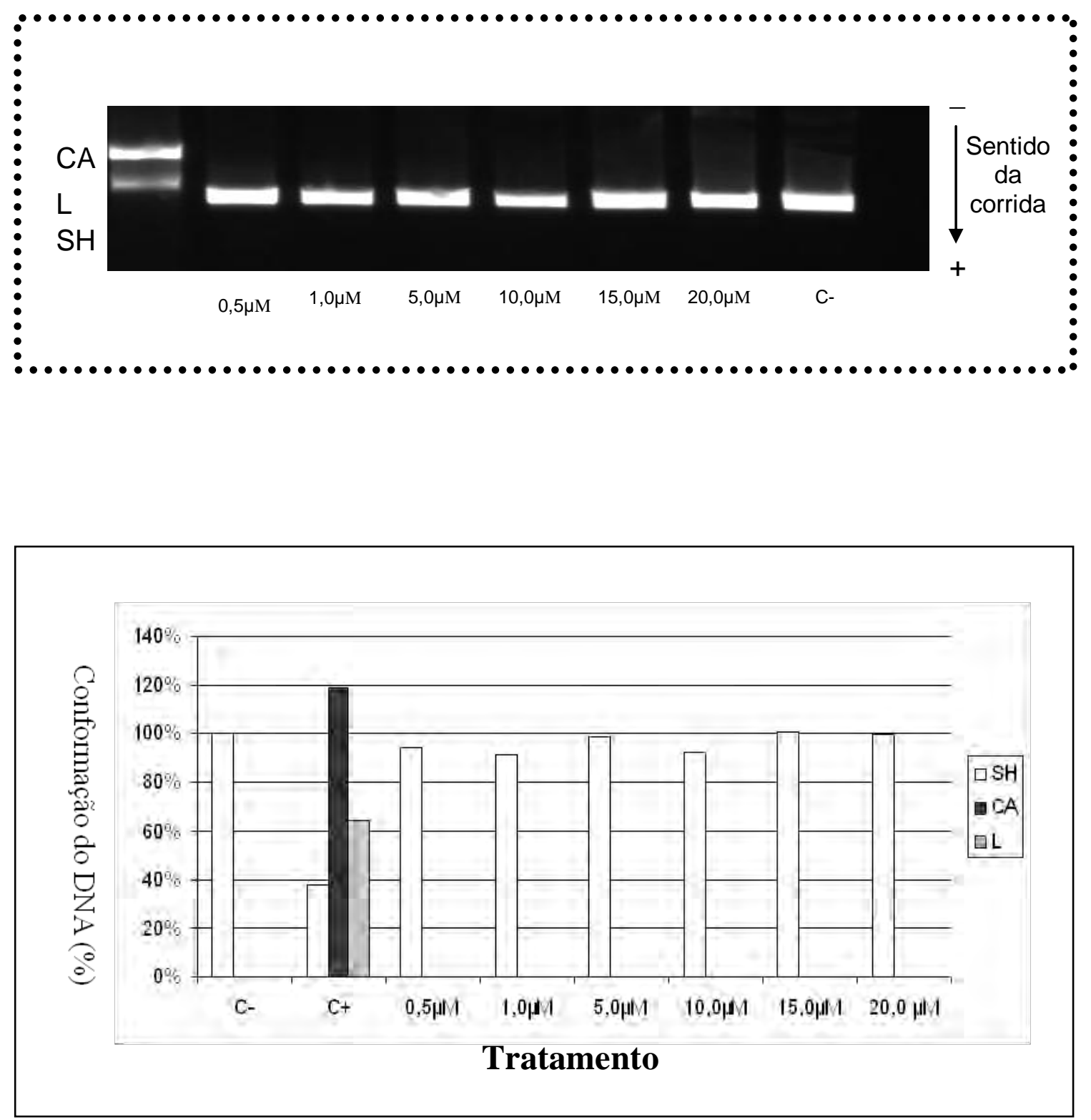

Figura 12. Eletroforese em gel de agarose a $0,8 \%$ e análise densitométrica das concentrações das conformações superhelicoidizada (SH), circular aberta (CA) e linear (L) do plasmídeo pUC9.1, após tratamento com o ligante dmba. Controle -

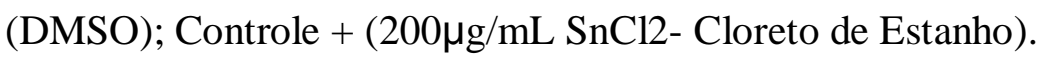



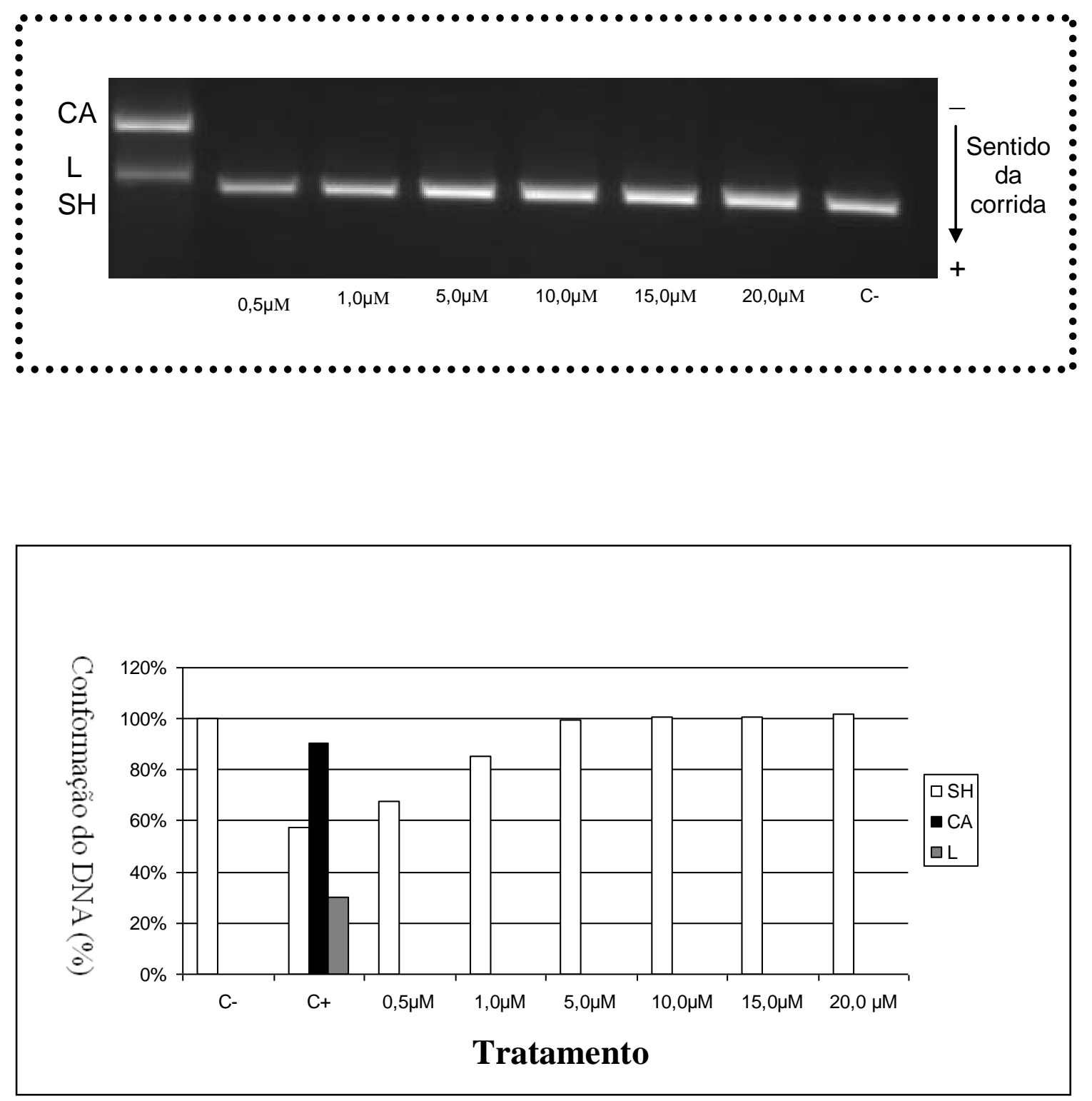

Figura 13. Eletroforese em gel de agarose a $0,8 \%$ e análise densitométrica das concentrações das conformações superhelicoidizada (SH), circular aberta (CA) e linear (L) do plasmídeo pUC9.1, após tratamento com o ligante tu. Controle (DMSO); Controle + $(200 \mu \mathrm{g} / \mathrm{mL}$ SnCl2- Cloreto de Estanho $)$. 

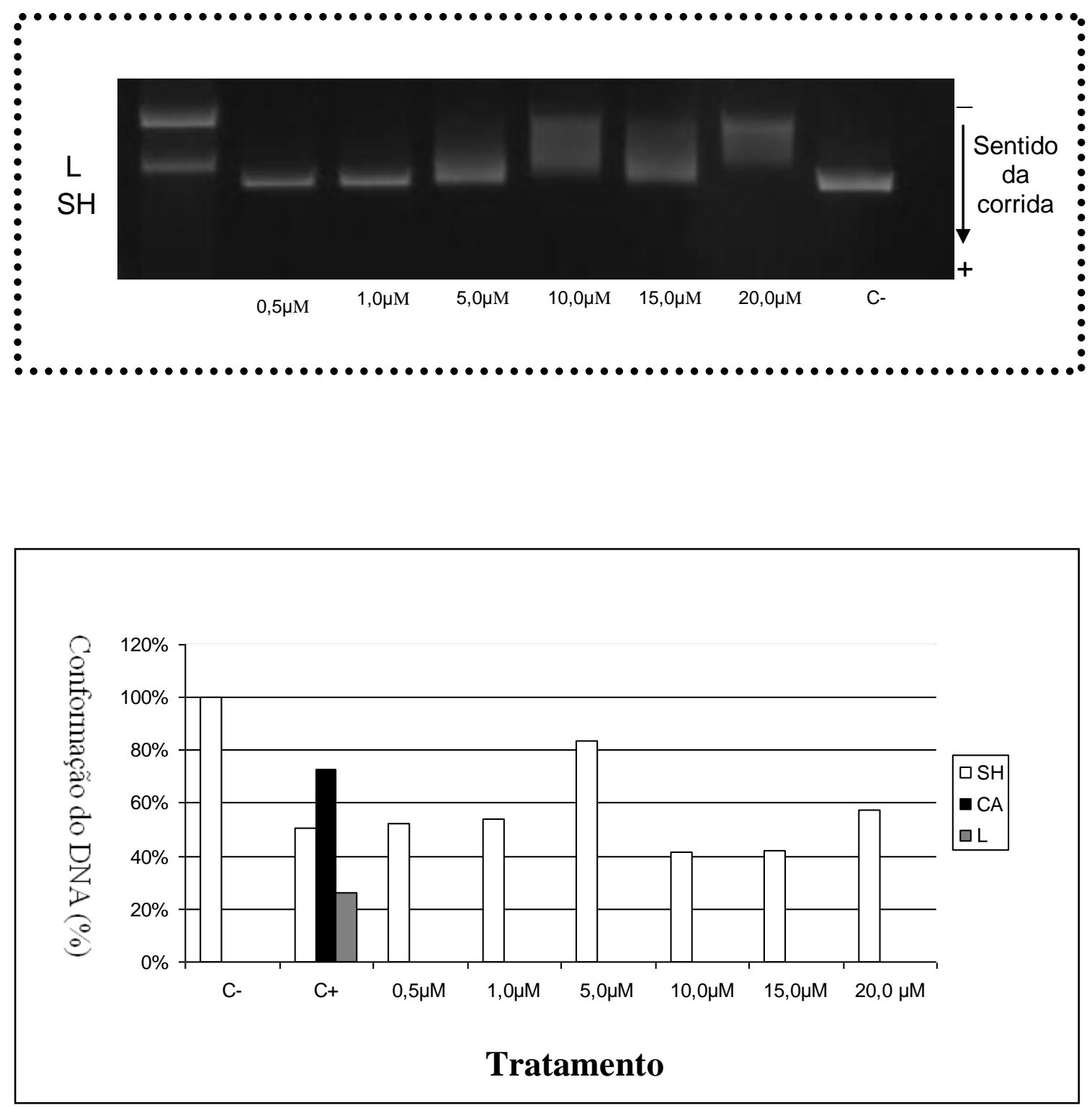

Figura 14. Eletroforese em gel de agarose a $0,8 \%$ e análise densitométrica das concentrações das conformações superhelicoidizada (SH), circular aberta (CA) e linear (L) do plasmídeo pUC9.1, após tratamento com cis-platina. Controle (DMSO); Controle + $(200 \mu \mathrm{g} / \mathrm{mL} \mathrm{SnCl2}$ - Cloreto de Estanho $)$. 


\section{DISCUSSÃO}

Muitos metais têm um papel importante nos sistemas vivos, uma vez que se ligam e interagem com moléculas biológicas tais como proteínas e o DNA, e apresentam afinidade por moléculas cruciais para a vida, tais como a de oxigênio $\left(\mathrm{O}_{2}\right)$, ou a de óxido nítrico (NO). Sendo assim, a evolução natural incorporou os metais às funções essenciais à vida. Sabemos que o transporte de oxigênio e de elétrons é feito respectivamente pelo ferro da hemoglobina e dos citocromos, que o zinco exerce função estrutural importante, e que minerais contendo cálcio são constituintes dos ossos. No entanto, somente nos últimos cem anos as propriedades medicinais de compostos inorgânicos começaram a ser investigadas de forma racional, com o emprego de compostos de ouro no tratamento da tuberculose, dos antimoniais para o tratamento de leishmaniose e de compostos à base de arsênio para o tratamento da sífilis (O`DWYER et al., 1999).

Desde então, houve um grande interesse por complexos metálicos como possíveis agentes terapêuticos, e iniciou-se uma nova era na busca por compostos metálicos com propriedades farmacológicas, investigação de mecanismos de ação e tentativas de melhorar a atividade de compostos já existentes. O interesse nas aplicações da química inorgânica em medicina continua a crescer, com a procura por novos alvos e novas oportunidades de intervenção da química de coordenação na química medicinal.

O câncer é uma das principais causas de morte no mundo todo, sendo a segunda maior causa de morte nos países industrializados depois de doenças cardiovasculares, destacando-se o câncer de mama pela alta incidência e elevada taxa de mortalidade entre as mulheres (AMERICAN CANCER SOCIETY, 2009).

Os três principais tipos de tratamento do câncer são a radioterapia, a cirurgia e a quimioterapia, sendo essa última, objeto de estudo nas últimas quatro décadas. A 
quimioterapia do câncer dispõe tanto de compostos orgânicos, como por exemplo, o taxol, a vimblastina e a doxorrubicina, quanto de compostos inorgânicos contendo metais, por exemplo, a carboplatina e a cis-platina (cis-Pt) (BOULIKAS e VOUGIOUKA, 2003).

A inibição do crescimento tumoral pelo emprego da cis-Pt foi atribuída a várias propriedades, incluindo a penetração na membrana celular por difusão passiva (JAMIESON e LIPPARD, 1999) ou por transporte ativo (SHERMAM e LIPPARD, 1987; ISHIDA et al., 2002; LIN et al., 2002) acúmulo no núcleo da célula tumoral e interação com o DNA, sendo essa última, a chave que leva à inibição do crescimento tumoral (JAMIESON e LIPPARD, 1999; KOMEDA, 2003). Porém alguns obstáculos têm sido enfrentados no uso da cisplatina, como o surgimento de resistência celular, baixa solubilidade em água, estreito espectro de atividade, além de graves efeitos colaterais, como neurotoxicidade, nefrotoxicidade e toxicidade ao trato intestinal, que se manifestam através de náuseas e vômitos intensos. Os efeitos adversos surgem principalmente pela complexação da cisplatina com proteínas e peptídeos, como por exemplo, a glutationa, o que leva ao seu acúmulo no organismo e conseqüente toxicidade (DECATRIS et al., 2004).

Devido as diversas desvantagens associadas à $c i s$-Pt, existe uma crescente busca por novas drogas citotóxicas e citostáticas, com ações antitumorais, porém mais seletivas, com menor incidência de toxicidade sistêmica. Dessa forma estudos utilizando complexos de paládio (II) permitiram observar que os mesmos apresentam ligações cruzadas com o DNA levando à morte celular por apoptose (QUIROGA et al., 1998a).

Segundo McAULIFFE et al. (1991) e Navarro-Ranninger et al. (1996), os compostos organometálicos de paládio (II) apresentam uma atividade antitumoral 
pequena quando comparados aos compostos contendo platina, devido a sua alta labilidade exibida em meio biológico.

No presente trabalho foram realizados ensaios biológicos para determinar a atividade imunológica e mutagênica de compostos inéditos de Paládio II, $[\mathrm{Pd}(\mathrm{dmba})(\mathrm{Cl}) \mathrm{tu}],\left[\mathrm{Pd}(\mathrm{dmba})\left(\mathrm{N}_{3}\right) \mathrm{tu}\right]$ de seus ligantes dmba e tu, assim como da cisplatina em modelo experimental de Ehrlich.

Para iniciar o estudo do efeito dos compostos sobre o sistema imunológico foi necessário determinar inicialmente a toxicidade destas substâncias sobre os macrófagos peritoneais murinos de animais não portadores, animais portadores do tumor de Ehrlich e sobre as células tumorais, com tempo de incubação de 24 hrs. Isto porque após as células serem retiradas de seu ambiente natural para utilização in vitro, as mesmas encontram-se fragilizadas e a garantia de sua viabilidade é fundamental para a análise de seu comportamento frente a estímulos (FRESHNEY, 1994). Na Tabela 1 foi possível observar que os macrófagos obtidos de animais não portadores e animais portadores do tumor de Ehrlich na sua forma sólida, são sensíveis ao potencial tóxico dos compostos, assim como, ao da droga padrão cisplatina, quando incubados por $24 \mathrm{~h}$.

Observou-se ainda, que para os animais não portadores de tumor o ligante tu apresentou um maior potencial citotóxico (menores concentrações) quando comparados à droga padrão $(10,01 \pm 0,7 \mu \mathrm{M}$ e 71,69 $\pm 2,15 \mu \mathrm{M})$ respectivamente, demonstrando alto potencial citotóxico em relação à cis-platina. Já nos animais portadores do tumor na sua forma sólida a cis-platina foi quem apresentou maior potencial citotóxico $(113,21 \pm$ $0,28 \mu \mathrm{M})$, quando comparado com os compostos porém os compostos denominados $1 \mathrm{e}$ 2 apresentaram um índice de citotoxicidade mediano $\left(\mathrm{IC}_{50}\right)$ similares ao da cis-platina $(137,65 \pm 0,22 \mu \mathrm{M}$ e $146,51 \pm 2,67 \mu \mathrm{M})$ respectivamente, o que também se faz favorável para os compostos. 
Em relação à sensibilidade das células tumorais de Ehrlich (Tabela 2), esta se mostrou tão sensível quanto às outras linhagens celulares citadas na literatura ao potencial tóxico dos compostos (NAVARRO-RANNINGER et al., 1996; QUIROGA et al., 1998; QUIROGA et al., 1999), sendo que o composto $2(39,70 \pm 0,30 \mu \mathrm{M})$ apresentou índice de citotoxicidade mediano próximo ao da cis-platina $(40,28 \pm 2,97$ $\mu \mathrm{M})$, e ainda apresentou um valor de $\mathrm{IC}_{50}$ inferior quando comparado ao composto 1 $(79,80 \pm 3,2 \mu \mathrm{M})$. Já em relação aos ligantes, a tiouréia foi quem apresentou o menor índice $(10,98 \pm 3,4 \mu \mathrm{M})$. Esses resultados demostram que o composto 2 com citotoxicidade similar ao da cis-platina pode refletir uma semelhança à atividade observada por essa, resultados que poderão ser confirmados posteriormente.

Uma variedade de compostos ciclometalados foi utilizada com sucesso, como compostos apresentando atividade citotóxica, especialmente sobre linhagens de células tumorais sensíveis e resistentes à cis-Pt. MORO et al., (2009) verificaram a atividade antitumoral dos compostos de fórmula geral $\left[\operatorname{Pd}\left(C^{2}, N \text {-dmba }\right)(\mu-\mathrm{X})\right]_{2}[\mathrm{dmba}=N, N$ dimethylbenzylamina; $\mathrm{X}=\mathrm{Cl}, \mathrm{Br}]$ e $\left[\mathrm{Pd}\left(C^{2}, N\right.\right.$-dmba $\left.)(\mathrm{X}) \mathrm{tu}\right][\mathrm{X}=\mathrm{Cl}, \mathrm{Br}]$ frente às linhagens LM3 e LP07, de câncer de mama e pulmão respectivamente, as quais apresentaram potencial citotóxico in vitro, resultados esses obtidos em nosso laboratório.

Em outros estudos, relatou-se a citotoxicidade de compostos derivados do paládio em duas linhagens leucêmicas (HL60 e K562) avaliadas pelo teste de redução utilizando o sal de tetrazólio (MTT) e ainda pelo método de exclusão pelo Azul de Tripan, sugerindo que os compostos apresentam potenciais tóxicos que seguem uma curva dose-dependente (ROCHA et al., 2003).

Os macrófagos uma vez ativados sofrem um processo diferenciado, caracterizado por um rápido aumento no metabolismo, motilidade e atividade fagocítica, 
passando a secretar mais de cem produtos, como enzimas, componentes do complemento, fatores de coagulação, espécies reativas de oxigênio e nitrogênio, citocinas entre outros (STITES et al., 2000).

Para avaliar a atividade dos compostos sobre a imunidade inata, nesse estudo foi observada a produção de reativos intermediários de oxigênio e nitrogênio ( $\mathrm{NO}$ e $\mathrm{H}_{2} \mathrm{O}_{2}$ ), assim como a produção de citocinas pró-inflamatórias como TNF- $\alpha$, IL-1, IL-6, IL-12 e anti-inflamatória como a IL-10.

Após estimulação, os fagócitos mono e polimorfonucleares sofrem mudanças em seu metabolismo, aumentando o consumo de $\mathrm{O}_{2}$ a níveis até 50 vezes superiores aos observados nas células não estimuladas. Concomitantemente, ocorre um aumento da oxidação com produção de adenina-difosfato-nicotinamida oxidase (NADPH) que leva a redução do $\mathrm{O}_{2}$ à $\mathrm{O}_{2}^{-}$, o qual por dismutação espontânea ou pela superóxido dismutase, leva à formação do $\mathrm{H}_{2} \mathrm{O}_{2}$ (DAHLGREN e KARLSSON, 1999; HALLIWELL e GUTTERIDGE, 1999; FORMAN e TORRES, 2001).

As espécies reativas de oxigênio (EROs) desempenham duplo papel nos sistemas biológicos, visto que podem ser tanto benéficas ou maléficas para o organismo. Dentre seus efeitos benéficos destacam-se a defesa contra agentes infecciosos e a sinalização de sistemas celulares. Em contraste, em altas concentrações, as EROs podem ser importantes mediadores no dano a estruturas celulares, incluindo lipídeos e membranas, proteínas, e ácidos nucléicos, sendo que tal dano oxidativo tem sido relatado como um fator importante no desenvolvimento de doenças como câncer, arteriosclerose, artrite, desordens neurodegenerativas e outras doenças (VALKO et al., 2006).

As figuras 3A e 3B mostram a produção de $\mathrm{H}_{2} \mathrm{O}_{2}$ em cultura de células peritoneais de camundongos não portadores e portadores do tumor sólido de Ehrlich na 
sua forma sólida, quando em contato com os compostos, ligantes e a cis-platina. Observou-se que utilizando o $\mathrm{IC}_{50}$ de $24 \mathrm{hrs}$ houve a estimulação de $\mathrm{H}_{2} \mathrm{O}_{2}$ pelos compostos, ligantes e cis-platina, naqueles animais não portadores do tumor. Já nos animais portadores de tumor de Ehrlich na sua forma sólida houve produção deste mediador apenas pelo ligante tu. Visto esta molécula ser ativada nos estágios iniciais da resposta imunológica, com o início do burst oxidativo (THOMASZ et al., 2007), nos animais não portadores do tumor, a produção da mesma provavelmente pode estar relacionada com a ação dos compostos no estágio inicial da resposta imune e até mesmo ela própria manipulação do animal.

Uma provável explicação de acordo com a literatura, a não produção de peróxido pelos compostos em animais portadores de tumor é que o crescimento do tumor de Ehrlich induz uma inibição das enzimas superóxido dismutase e catalase (SUN et al., 1989), as quais são fundamentais na eliminação dos radicais livres como o ânion superóxido e $\mathrm{H}_{2} \mathrm{O}_{2}$ (RUSHMORE e PICKET, 1993).

Já o NO é uma molécula reativa produzida a partir da enzima NO sintase induzível (iNOS) que se encontra altamente expressa em macrófagos ativados com LPS (NATHAN, 1992; BENSINGER e TONTONOZ, 2008). A produção normal ou fisiológica de NO por fagócitos é benéfica para a defesa do hospedeiro contra microrganismos e parasitas, no entanto a superprodução de NO pode ser prejudicial e resultar em processos inflamatórios crônicos e agudos, além de atualmente estar relacionada com a promoção de angiogênese tumoral e metástase (THIEMERMANN e VANE, 1990; BOGDAN, 1998; CHEN e STONER, 2004). Em tumores de mama, inibidores da iNOS vem sendo utilizados na prevenção da angiogênese e além disto, a terapia para prevenção de metástases no câncer pode ser acompanhada pela inativação da iNOS (XIE e FIDLER, 1998; JADESKI e LALA, 1999). 
A determinação da produção de NO foi realizada pela técnica de detecção de nitrito nos sobrenadantes das culturas pelo reagente de Griess, onde foi utilizada a concentração ideal de cada composto $\left(\mathrm{IC}_{50}\right)$ de acordo com o teste de MTT após 24 hrs de exposição. Os resultados demonstraram que das amostras testadas nos macrófagos peritoneais murinos de animais não portadores de tumor (Fig. 4 A) o ligante dmba foi quem apresentou uma maior produção de NO quando comparado com o controle negativo $(\mathrm{p}<0,01)$ e quando comparado com a droga padrão $(\mathrm{p}<0,001)$, já para aqueles portadores do tumor de Ehrlich o composto 2 e cis-pt $(\mathrm{p}<0,001)$ foi quem apresentou maior produção de NO, seguido pelos ligantes tu $(\mathrm{p}<0,01)$ e dmba $(\mathrm{p}<0,05)$ (Fig. 4 B).

A estimulação da produção de NO em macrófagos através da expressão de iNOS é realizada por citocinas como TNF- $\alpha$, IL-1, IFN- $\gamma$ (CARLOS et al., 2004; MAIA et al., 2006). O NO e TNF- $\alpha$ possuem importantes papéis na patogênese de várias doenças durante a inflamação aguda (NATHAN, 1992). Além disto, o TNF- $\alpha$ atua como um fator de progressão de tumores através da modulação da motilidade tumoral ou pelo aumento da expressão de moléculas de adesão em órgãos alvos (GELIN et al.,1991; KUNDU, 2008). Portanto, a identificação de novos agentes farmacológicos que possam prevenir a superprodução de NO e TNF- $\alpha$ é de considerável interesse médico (MANJEET e GHOSH, 1999; CARLI et al., 2009).

O TNF- $\alpha$ pode induzir morte por necrose ou apoptose em algumas células tumorais humanas primárias e em linhagens celulares tumorais (CARSWELL et al., 1975; AGGARWAL \& NATARJAN, 1996; PALLADINO et al., 2003), incluindo linhagens de câncer de mama (BEN-BARUCH, 2003). Nos macrófagos peritoneais murinos de animais não portadores do tumor de Ehrlich os compostos 1, 2, ligante dmba e cis-platina induziram a produção de TNF- $\alpha(\mathrm{p}<0,001)$ quando comparado com o controle negativo (Fig. 5 A). Enquanto nos animais portadores do tumor de Ehrlich o 
composto 2 foi quem apresentou maior produção desta citocina $(\mathrm{p}<0,001)$ seguida do composto 1, cis-platina $(\mathrm{p}<0,01)$ e ligante tu $(\mathrm{p}<0.05)$ (Fig. 5 B), resultado esse que ressalta o composto 2 , uma vez que a estimulação da produção de TNF- $\alpha$ pode levar a apoptose em linhagens celulares tumorais (FIDLER e SCHROIT, 1998; BALKWILL e MATOVANI, 2001; BALKWILL, 2002) lembrando ainda, que houve uma diferença siginficativa da produção de TNF- $\alpha$, por esse composto quando foi comparado com a cis-platina $(\mathrm{p}<0,05)$.

Inter-relacionadas com a citocina TNF- $\alpha$ estão os mediadores IL-6 e IL-1, sendo que estes podem atuar cooperativamente, sugerindo que estas três citocinas formam uma rede de fatores que afetam a progressão tumoral. Atualmente, muitos estudos in vitro e in vivo têm avançado na compreensão do envolvimento das citocinas na oncologia (NICOLINI et al., 2006).

A IL-1 induz a proliferação e a ativação de macrófagos, e também possui a capacidade de aumentar a citotoxicidade e inibir o crescimento das células tumorais do câncer de mama e melanoma (LASKIN et al., 2001; KUNINAKA et al, 2000). Por outro lado a IL-1 estimula a expressão de potentes fatores angiogênicos estimulando a neovascularização tumoral (TORISU et al., 2000; NAKAO et al., 2005). A IL-6, por sua vez, é uma citocina chave para o crescimento tumoral, além de desempenhar função pró-inflamatória e anti-apoptótica em ratos (NAUGLER et al., 2007).

Em nosso estudo os compostos organometálicos testados em macrófagos peritoneais murinos de animais não portadores de tumor o composto 2 e o ligante dmba ( $p<0,001)$, seguido do ligante tu $(p<0,01)$ produziram níveis significativos de IL-1 $\beta$ em relação ao controle negativo (Fig. 6 A), e ainda o composto 2 e o ligante dmba apresentaram diferença significativa quando comparados com a droga padrão $(\mathrm{p}<0,01)$. 
Naqueles animais portadores do tumor de Ehrlich não houve uma produção significativa desta citocina (Fig. 6 B).

Em contrapartida houve uma grande produção da citocina IL-6 pelos macrófagos peritoneais murinos de animais sadios onde o composto $2(\mathrm{p}<0,001)$, seguido pelo composto 1 e pelo ligante dmba $(\mathrm{p}<0,01)$ apresentaram maior produção desta, quando comparado com o controle negativo (Fig. 7 A), ainda o composto 2 apresentou uma diferença significativa quando comparado com a cis-platina $(\mathrm{p}<0,01)$. Naqueles portadores do tumor de Erlich na sua forma sólida os compostos 1, 2, ligante dmba e cis-platina $(\mathrm{p}<0,001)$, seguidos pelo ligante tu $(\mathrm{p}<0,01)$ foram os que apresentaram a maior produção da mesma (Fig. 7 B).

Analisando-se o perfil de produção dessas três citocinas pelos animais portadores de tumor, o composto 2 , seguido pelo ligante dmba, de uma maneira geral foi quem apresentou maior produção de IL-6 e TNF- $\alpha$, indicativo, portanto de uma ação proinflamatória quando os macrófagos foram desafiados podendo assim auxiliar na modulação da progressão tumoral, tal como observado por Nicolini et al., 2006. Quanto à IL-1, não foi observado a sua produção em animais portadores de tumor, isso pode estar relacionado com a produção de TNF- $\alpha$, uma vez que esses mediadores compartilham muitas atividades entre si.

Um outro dado interessante a comentar é que a produção dessas citocinas proinflamatórias (TNF- $\alpha$, IL-6 e IL-1) localmente ou sistemicamente pode afetar o crescimento e metástase das células tumorais (KUNINAKA, et. al., 2006). Tem sido relatado que a IL-1 e o TNF- $\alpha$ inibem o crescimento das células tumorais do câncer de mama e melanoma malignos, e carcinoma de células renais (KUNINAKA et al., 2000; CHOI et al., 2008). 
Além disso, tanto TNF- $\alpha$ quanto IL-1 parece atuarem como um fator de progessão do tumor em relação à modulação da mobilidade tumoral (MURLLER, et. al., 1996). Já a citocina IL-6 promove o crescimento das células tumorais malignas em melanoma, carcinoma de células renais, e câncer cervical. Entretanto, resultados contrários também têm sido reportados. Serve et al., (1991) relatam que a IL-6 não tem nenhum efeito significativo em 26 linhagens de células tumorais, incluindo linhagens celulares de câncer de pulmão. Devido a isso, é importante esclarecer a influência direta de citocinas pró-inflamatórias em células tumorais, a fim de obter uma melhor compreensão da terapia anti-tumoral.

De maneira semelhante às demais citocinas a Interleucina-12 (IL-12) é uma citocina multifuncional que estimula a imunidade inata e adaptativa direcionando o sistema imunológico à resposta imune $\mathrm{Th}_{1}$, essencialmente celular, necessária à eliminação tumoral. As funções imunomoduladoras e antiangiogênicas da IL-12 tornam esta citocina um agente antineoplásico (BARNES, 2003; BERRAONDO et al., 2009).

Na figura $8 \mathbf{A}$ podemos observar que os compostos 2, 1 e o ligante dmba apresentaram uma maior produção de IL-12 (p<0,001) seguidos pela cis-platina $(\mathrm{p}<0,01)$ em relação ao controle negativo, ainda quando comparado o composto 2 com a cis-platina houve uma diferença significativa entres estes $(\mathrm{p}<0,01)$. Nos animais portadores do tumor, a maior produção desta foi induzida pelo ligante dmba $(p<0,01)$ seguida pelo composto 2, ligante tu e cis-platina, em realação ao controle negativo (p<0,05) (Fig. 8B). Dados observados por Berraondo et. al., (2009) demosntram que a administração de IL-12 recombinante em modelos animais em estudos pré-clínicos de câncer e hepatite viral crônica, foi considerada um poderoso agente terapêutico contra as duas doenças. A produção local de IL-12 utilizando vetores de expressão nas células tumorais pode estimular a infiltração de células imunes efetoras levando a regressão do 
tumor. Resultados semelhantes já eram descritos por Brunda et al., (1993) bem como Tahara et al., (1993) e Nastala et al., (1994) mostrarando que a IL-12 era um potente mediador antitumoral in vivo com atividade antimetastática contra tumores murinos. Curiosamente, a eficácia da IL-12 foi bastante reduzida, mas não abolida, em camundongos imuno-incompetentes (DEL FECCHIO et. al., 2007). Assim a produção de IL-12 pelo ligante dmba e composto 2 mais uma vez, tentam comprovar a ação destes na inibição da progressão tumoral.

Considerando que de maneira oposta ao $\mathrm{NO}$ e a todas as citocinas citadas acima, a IL-10 apresenta características antiinflamatórias, através da inibição da ativação dos macrófagos (CLEMONS et al., 2000; NAUNDORF et al., 2009) em nosso estudo, foi observado que não houve produção desta citocina por animais não portadores e portadores do tumor de Ehrlich após 24 hrs de incubação (Fig. 9A e Fig. 9B).

Fernandez, et. al., (2006), relatam que a expressão de IL-10 inibe a resposta imune no local do tumor, e sua relação com a presença de apoptose pode sugerir um aumento da agressividade do tumor, mesmo em estágios iniciais de seu desemvolvimento. Por outro lado, Huang, et. al., (1996) sugerem que a produção de IL10 por macrófagos associados ao tumor inibem fatores angiogênicos e consequentemente o crescimento do mesmo.

Além da avaliação da atividade imunomoduladora, outro aspecto importante a ser analisado é o efeito de substâncias antitumorais sobre o DNA propriamente dito. A conversão de células normais em células neoplásicas normalmente envolve vários passos. Uma das fases iniciais desse processo envolve a ação de um carcinógeno genotóxico (WEISBURGER, 2000).

Um dos objetivos desse trabalho foi avaliar a ação dos compostos, ligantes e cisplatina quanto ao seu potencial de indução de danos ao DNA. Para tanto, foi utilizado o 
teste de mutação gênica reversa com $S$. typhimurium (teste de Ames), que é um teste rápido amplamente aceito para identificar uma grande variedade de compostos químicos capazes de induzir danos no material genético, levando ao aparecimento de mutações gênicas (MORTELMANS e ZEIGER, 2000). Foram utilizadas as linhagens TA102 e TA98 de S. typhimurium, capazes de promover uma triagem abrangente de diferentes compostos primários e secundários, com vários mecanismos de ação, e os testes foram realizados com e sem ativação metabólica (S9). A cepa TA 98 apresenta mutações no gene hisD (hisD 3052) que codifica para a histidinol desidrogenase, apresentando como ponto preferencial para reversão de 8 resíduos repetitivos de CG e detecta compostos mutagênicos que causam deslocamento no quadro de leitura do DNA. Já a TA 102, provoca mutações ochre TAA no gene his G e detecta mutágenos como formaldeído, glioxal, hidroperóxidos, bleomicina, fenilhidrazina entre outros (MARON e AMES, 1983).

Nos ensaios, com as linhagens TA102 e TA98 tratadas com os compostos e ligantes não apresentaram qualquer efeito mutagênico, com ou sem ativação metabólica, para os compostos: $1[\mathrm{Pd}(\mathrm{dmba})(\mathrm{Cl}) \mathrm{tu}], 2\left[\mathrm{Pd}(\mathrm{dmba})\left(\mathrm{N}_{3}\right) \mathrm{tu}\right]$, e seus ligantes dmba e Tu. Entretanto foi observada citotoxicidade para a cis-platina (Tabelas 3, 4, 5 e 6).

Verifica-se que não houve aumento da freqüência normal de mutantes revertentes e os valores de RM ficaram todos abaixo de dois, com exceção da cisplatina que apresentou valores de RM que variaram de 2,05 a 2,08 para linhagem TA102 e 2,09 a 2,66 para linhagem TA98 o que indica a presença de compostos capazes de ocasionar danos genéticos por substituição de pares de base e frameshift respectivamente.

Bünger, et. al., (1996), comparou a mutagenicidade, pelo Teste de Ames, entre compostos contendo platina, paládio e ródio e comprovou que somente os compostos contendo platina, apresentaram-se mutagênicos frente as linhagens testas. 
Sendo assim, um resultado favorável aos compostos, que diferente da cisplatina não foram capazes de provocar mutações gênicas no genoma da bactéria $S$. typhimurium.

O potencial genotóxico dos compostos, ligantes e cis-platina também foram avaliados através de ensaios com DNA plasmidial pUC9.1. A indução de quebras no DNA altera a estrutura terciária superhelicoizada do DNA plasmidial, modificando também a sua mobilidade eletroforética (YOSHINO et al., 1999). Assim, o tratamento do DNA plasmidial com diferentes compostos, seguido de análise por eletroforese, permite verificar a ocorrência de quebras nessa macromolécula induzida por esses compostos.

Após tratamento do DNA plasmidial com os compostos, ligantes e cisplatina, observou-se que em todas as concentrações testadas para o composto 1 (Fig. 10), composto 2 (Fig. 11), ligante dmba (Fig. 12), ligante tu (Fig.13) e cis-platina (Fig. 14), não houve indício de quebras nas fitas do DNA plasmidial em nenhuma concentração testada de todos os ensaios realizados, com exceção da cis-platina, que apresentou um arraste no gel, característico de múltiplas quebras, portanto assim, não permitindo a visualização das bandas formadas . È conhecida a capacidade da cis-platina de promover cross-link entres as bases de guanina e quebrando desta forma o DNA, reduzindo assim sua mobilidade eletroforética (HERMANet. al., 2008).

Serão necessários outros ensaios para confirmar a não interação dos compostos e ligantes com o DNA, visto que estes possam interagir de outra forma, como por exemplo por aneogênese, agindo sobre as fibras do fuso, impedindo assim que a divisão celular ocorra.

Baseando-se nos resultados obtidos, muitas vezes de forma igual ou superior à cis-platina e levando em consideração os testes aqui realizados, podemos propor que os 
compostos sejam promissores agentes, devido a seus efeitos sobre as células tumorais de Ehrlich e imunológicas e ainda apresentaram - se não indutores de mutação gênica e não foram capazes de provocar quebras no DNA “in vitro”.

Deve-se ressaltar que muitos outros estudos serão necessários, visto que os compostos são inéditos, e muito ainda falta ser descoberto sobre os mesmos e que testes sobre culturas celulares in vitro nem sempre correspondem aos observados em situações in vivo (BABICH e TIPTORB, 2002). 


\section{CONCLUSÕES}

Os resultados obtidos permitem concluir que os macrófagos peritoneais de animais não portadores e animais portadores do tumor de Ehrlich na sua forma sólida, assim como células tumorais de Ehrlich são sensíveis ao potencial tóxico dos compostos, seus ligantes e cis-platina.

Os compostos estimulam a produção de óxido nítrico, peróxido de hidrogênio e de citocinas pró-inflamatórias como IL-1 $\beta$, IL-12, IL-6 e TNF- $\alpha$, contrariamente não promovem a produção de citocinas anti-inflamatórias como no caso da IL-10. Sendo que o composto de fórmula geral $\left[\mathrm{Pd}(\mathrm{dmba})\left(\mathrm{N}_{3}\right) t u\right](2)$ e o ligante dmba apresentam um maior potencial pro-inflamatório (quando comparado ao composto $[\mathrm{Pd}(\mathrm{dmba})(\mathrm{Cl}) \mathrm{tu}]$ (1) e ao ligante tu.

A avaliação da mutagenicidade demonstrou que os compostos e os ligantes não foram mutagênicos in vitro, diferente da cis-paltina que se apresentou mutagênica, pelo teste de Ames. E não são capazes de promoverem quebras nas fitas do DNA plasmidial, em ensaios com plasmídio pUC9.1.

Levando em consideração a não mutagenicidade dos compostos e de seus ligantes, assim como a capacidade dos mesmos de estimularem a produção de citocinas pró-inflamatórias em animais portadores do tumor de Ehlich, estes se demonstram promissores quando comparados a $c i s-\mathrm{Pt}$, uma vez que esta mesmo sendo capaz de estimular o sistema imune, provoca elevada toxicidade e mutagenicidade no DNA. 


\section{Seferéncias}


ABBAS, A.K.;LICHTMAN, A.H.;POBER, J.S. Imunologia celular e molecular. 4.ed.Rio de Janeiro: Revinter, 2003. p.23; 236; 240; 276;282; 301-302.

ADAMS, D.O., HAMILTON, T.A. The cell biology of macrophage activation. Annu. Rev. Immunol., v. 2, p. 283-318, 1984.

AGGARWAL, B.B.; NATARJAN, K. Tumor necrosis factors: developments during the last decade. Eur. Cytokine Netw., v.7, p.93-124, 1996.

ALLAVENA, P.; SICA, A.; SOLINAS, G.; PORTA, C.; MANTOVANI, A. The inflammatory micro-environment in tumor progression: the role of tumor-associated macrophages. Critical Reviews in Oncology/Hematology. v. 66, p.1-9, 2008.

AMERICAN CANCER SOCIETY. Cancer facts and figures 2004. Atlanta, 2004. 60 p. Disponível em: www.cancer.org Acesso em: 13 nov. 2009.

ANANIAS, S.R.; SANTANA, A.M.; MAURO, A.E.; DE LUCCA NETO, V.A.; DE ALMEIDA, E.T. Reação de bis-inserção de 1,2-difenilacetileno na ligação Pd-C de ciclometalados. Quim. Nova, v.26, p.53-55, 2003.

BERGENDI, L.; BENES, L.; DURACKOVA, Z.; FERENCIK, M. Chemistry, physiology and pathology of free radicals. Life Sci., v.65, p.1865-1874, 1999.

BABICH, H.; TIPTORB, D. A. In vitro response of human gingival epithelioid S-G cells to minocycle. Toxicol. in vitro, v.16, p.11-21, 2002.

BALKWILL, F. Tumor necrosis factor or tumor promoting factor?. Cytokine Growth Factor Rev., v.13, p.135-141, 2002.

BALKWILL, F.; MANTOVANI, A. Inflammation and cancer: back to Virchow? Lancet, v.357, p.539-545, 2001.

BARNES, P.J. Cytokine-directed therapies for the treatment of chronic airway diseases. Cytokine and Growth Factor Rev., v.14, p.511- 522, 2003.

BECKMAN, J.S.; KOPPENOL, W.H. Nitric oxide, superoxide, and peroxynitrite: the good, the bad, and ugly. Am. J. Physiol., v.271, p. 1424-37, 1996.

BEN-BARUCH, A. Host microenvironment in breast cancer development: inflammatory cells, cytokines and chemokines in breast cancer progression: reciprocal tumor-microenvironment interactions. Breast Cancer Res., v.5, p.31-36, 2003.

BENSINGER, S.J.; TONTONOZ, P. Integration of metabolism and inflammation by lipid-activated nuclear receptors. Nature. v.454, p. 470-477, 2008.

BERRAONDO, P.; PRIETRO, J.; GONZALES-ASEQUINOLAZA, G. Advances in Interleukin-12 Gene Therapy for Acquired Liver Diseases. Current Gene Therapy, v. 10, p. 62-71, 2009. 
BILLACK, B. Macrophage Activation: Role of Toll-like Receptors, Nitric Oxide, and Nuclear Factor kappa B. Am. J. P. Education., v. 70, p. 1-10, 2006.

BIRD, S.; ZOU, J.; WANG, T.; MUNDAY, B.; CUNNINGHAM, C.; SECOMBES, J. Evolution of interleukin-1 beta. Cytokine Growth Factor Rev., v. 13, p. 483-502, 2002.

BOGDAN, C. The multiplex Function of Nitric Oxide in (Auto) immunity J.Exp.Med., v.187, n.9, p.1361-1365, 1998.

BOGDAN, C. Nitric oxide and the immune response, Nat. Immunol., v.2, p. 907-916, 2001.

BOULIKAS, T.; VOUGIOUKA, M. Cisplatin and platinum drugs at the molecular level. Oncol. Rep., v.10, p.1663-1682, 2003.

BRUNDA, M.J.; LUISTRO, L.; WARRIER, R.R. Antitumor and antimetastatic activity of interleukin 12 against murine tumors. J. Exp. Med., v.30, p.178-1223, 1993.

BÜNGER, J.; STORK, J.; STALDER, K. Cyto- and genotoxic effects of coordination complexes of platinum, palladium and rhodium in vitro. Int. Arch. Occup. Environ. Health., v.69, p.33-38, 1996.

CAIRES, A.C.F.; ALMEIDA, E.T.; MAURO, A.E.; HEMERLY, J.P.; VALENTINI, S.R. Síntese e atividade citotóxica de alguns azido-ciclopaladados estabilizados com ligantes bifosfínicos. Quim. Nova., v.22, p.329-334, 1999.

CARLI, C.B.A.; MATOS, D.C.; LOPES, F.C.M.; MAIA, D.C.G.; DIAS, M.B.; SANNOMIYA, M.; RODRIGUES, C.M.; ANDREO, M.A.; VILEGAS, W.; COLOMBO L.L.; CARLOS I. Z. Isolated Flavonoids against Mammary Tumour Cells LM2. Z. Naturforsch., (in press).

CARLOS, I.Z.; MONNAZZI, L.G.S.; FALCÃO, D.P.; DE MEDEIROS, B.M.M. TNF , $\mathrm{H}_{2} \mathrm{O}_{2}$ and $\mathrm{NO}$ response of peritoneal macrophages to Yersinia terocolitica O:3 derivatives. Microb. Infect., v. 6, p.207-212, 2004.

CARSWELL, E.A.; OLD, L.J.; KASSEL, R.L.; GREEN, S.; FIORE, N.; WILLIAMSON, B. An endotoxin-induced serum factor that causes necrosis of tumors. Proc. Natl. Acad. Sci. USA., v.72, p.3666-3670, 1975.

CASALE, T.B.; COSTA, J.J.; GALLI, S.J. TNF- $\alpha$ is important in human lung allergic reaction. Am. J. Respr. Cell Mol. Biol., v.15, p.35-44, 1996.

CLEMONS, K.V.; DARBONNE, W.C.; CURNUTTE, J.T.; SOBEL, R.A.; STEVENS, D.A. Experimental histoplasmosis in mice treated with anti-murine interferon-gamma antibody and in interferon-gamma gene knockout mice. Microbes Infect.,v.2, p.9971001, 2000. 
CHEN, T.; STONER, G.D. Inducible nitric oxide synthase expression in Nnitrosomethylbenzylamine (NMBA)-induced rat esophageal tumorigenesis. Mol. Carcinog., v.40, p.232-240, 2004.

CHOI, S.K; PARK Y.S.; CHOI D.K.; CHANG H.I. Effects of Astaxanthin on the Production of NO and the Expression of COX-2 and iNOS in LPS-Stimulated BV2 Microglial Cells. J. Microbiol. Biotechnol., v.18, p.1990-1996, 2008.

COSTA, F.R. Avaliação dos efeitos de compostos organometálicos de Paládio (II) em culturas de células. 2004. 74 f. Dissertação (Mestrado em Análises Clínicas) Faculdade de Ciências Farmacêuticas, Universidade Estadual Paulista, Araraquara, 2004.

COUSSENS, L.M.; JACKS, T. Genetic and cellular mechanisms of oncogenesis.

Genectis and development. v.18, p.1-2, 2008.

DAHLGREN, C.; KARLSSON, A. Respiratory burst in human neutrophils. J. Immunol. Methods, v.232, p.3-14, 1999.

DAWE, C.J. Comparative neoplasia. In: HOLLAND, J.F. \& FREI III, E. Cancer medicine. 2. ed. Philadelphia : Lea \& Febiger, 1982. p. 209.

DE ALMEIDA, E.T.; MAURO, A.E.; SANTANA, A.M.; NETTO, A.V.G.; CARLOS, I.Z. Emprego de compostos organometálicos mononucleares de paládio(II) na ativação de macrófagos peritoneais de camundongos. Quim. Nova, v.28, p.405-408, 2005.

DE FLORA, S. Mechanisms of inhibitors of mutagenesis and carcinogenesis Assay. Mutation Research, v. 455, p. 29-60, 1998.

DE LUCCA NETO, V.A.; MAURO, A.E.; CAIRES, A.C.F.; ANANIAS, S.R.; DE ALMEIDA, E.T. Synthesis, characterization and thermal behaviour of cyclopalladated compounds of the type $\left[\mathrm{Pd}\left(\mathrm{C}_{6} \mathrm{H}_{4} \mathrm{CH}_{2} \mathrm{~N}\left(\mathrm{CH}_{3}\right)_{2}\right)(\mu-\mathrm{X})\right]_{2}(\mathrm{X}=\mathrm{CL}, \mathrm{NCO}, \mathrm{SCN}, \mathrm{CN})$ Polyhedron., v.18, p.413-417, 1999.

DEARFIELD, K.L.; CIMINO, M.C.; MCCARROLL, N.E.; MAUER, I.; VALCOVIC, L.R. Genotoxicity risk assessment: a proposed classification strategy. Mutation Research, V.521, p.121-135, 2002.

DECATRIS, M.P.; SUNDAR, S.; O'BYRNE, K.J. Platinum - based chemoterapy in metastatic breast cancer: current status. Cancer Treat. Rev., v.4, p.53-81, 2004.

DEL VECCHIO, M.; BAJETTA, E.; CANOVA, S.; LOTZE, M.T.; PARMIANI, A.G.; ANICHINI, A. Interleukin-12: Biological Properties and Clinical Application. Clin. Cancer Res., v.13, p. 4677-4685, 2007.

DINARELlO, C.A. Interleukin-1. In: THOMAS, A (Ed). The Cytokine Handbook. San Diego, CA: Academic Press, 1998. p.35-72.

EBERHARDET, M.K. Reactive oxygen metabolites: chemistry and medical consequences. Boca Raton: CRC Press, 2001.590 p. 
EHRLICH, P.; APOLANT, H. Beobachtungen über maligne Mausetumoren. Berl. Klin. Wschr., v.28, p.871-874, 1905.

EHRLICH, P. Experimentally carcinomstudien an Mäusen. Arb Inst Exp Ther Frankfurt., v.1, p.78-80, 1932.

FALKOFF, R.J..M.; MURAGUCHI, A.; HONG, J-X.; BUTLER, J.L.; DINARELLO, C.A.; FAUCI, A.S. The effects os interleukin 1 in human B cell activaction and proliferation. J.Immunol., v.131, p.801-805, 1983.

FECCHIO, D.; SIROIS, P.; RUSSO, M.; JANCAR, S. Studies on inflammatory response induced by Ehrlich tumor in mice peritoneal cavity. Inflammation, v.14, p.125-132, 1990.

FELDMANN, M.; BRENNAN, F. M.; MAINI, R. N. Role of cytokines in rheumatoid arthritis. Annu. Rev. Immunol., Palo Alto, v.14, p.397-440, 1996.

FERDINANDY, P. Peroxynitrite: just an oxidative/nitrosative stressor or a physiological regulator as well? Br. J. Pharmacol., v.148, p.1-3, 2006.

FERNÁNDEZ， L.L.; ÁLVAREZ-GOYANES I.L.; ARANGO-PRADOA， C.L.; ALCOCER-GONZÁLEZB, J.M.; MOJARRIETA, J.C.; PÉREZ, X.E.; LÓPEZ, O.M.; ODIO, S.F.; RODRÍGUEZ, R.C.; YI, M.E.G.; MARINA, M.V.; GUERRA, R.T.; PADILLA, C.R. Relationship between IL-10 and tumor markers in breast cancer patients. The Breast. v. 15, p. 482-489, 2006.

FILDER, I.J.; SCHROIT, A.J. Recognition and destruction of neoplasic cells by activated macrophages: discrimination of altered self. Biochim. Biophys. Acta, v.948, p.151-73, 1988.

FRESHNEY, R.I. Culture of animal cells: a manual of basic technique 3. ed. New York: Wily-Liss, 1994, 486p.

FORMAN, H.J.; TORRES, M. Redox signaling in macrophages. Mol. Aspects Med., v.22, p.189-216, 2001.

GALli, S.; LABATO, M.I.; JOFFÉ, E.B.K.; CARRERAS, M.C., PEDROSO, J.J. Decreased mitochondrial nitric oxide synthase activity and hydrogen peroxide relate persistent tumoral proliferation to embryonic behaviour. Cancer Res., v.63, p.63706377, 2003.

GAZZINELLI, K.T.; OSWALD, I.P.; JAMES, S.L.; SHER, A. IL-10 inhibits parasite killing and nitrogen oxide production by IFN- -activated macrophages. J.Immunol., v.148, p.1792, 1992. 
GELIN, J.; MOLDAWER, L.L.; LONNROTH, C.; SHERRY, B.; CHIZZONITE, R.; LUNDHOLM, K. Role of endogenous tumour necrosis factor- $\alpha$ and interleukin-1 for experimental tumour growth and the development of cancer cachexia. Cancer Res., 51, 415-421, 1991.

GREENBLATT, M.S., BENNETT, W.P., HOLLSTEIN, M., HARRIS, C.C. Mutations in the p53 tumor suppressor gene: clues to cancer etiology and molecular pathogenesis. Cancer Research., v.54. p.4855-4878, 1994.

GIBSON, P. R. Increased gut permeability in Crohn's disease: is TNF the link? Gut, v.53, n.12, p.1724-1725, 2004.

GREEN, L.C.; WAGNER, D.A.; GLOGOWSKI, J.; SKIPPER, P.L.; WISHNOK, J.S.; TANNENBAUM, S.R. Analysis of nitrate, nitrite and $\left[{ }^{15} \mathrm{~N}\right]$ nitrate in biological fluids. Anal. Biochem., v.126, p.131-138, 1982.

GUEDES, A.P., CARDOSO, V.N., MATTOS, J.C. P. DE, DANTAS, F. J. S., MATOS, V.C., SILVA, J.C.F., BEZERRA, R.J.A.C., CALDEIRA-DE-ARAÚJO, A. Cytotoxic and genotoxic effects induced by stannous chloride associated to nuclear medicine kits. Nuclear Medicine and Biology. V.33. p.915-921, 2006.

HAHN, W.C., Weinberg, R.A. Rules for making human tumor cells. New England Journal of Medicine., v.347, p.1593-603, 2002.

HALLIWELL, B.; GUTTERIDGE, J.M.C. (Eds.). Free radicals in biology and medicine. New York: Oxford University Press Inc., 1999.

HAYATSU, H.; ARIMOTO, S.; NEGISHI, T. Dietary inhibitors of mutagenesis and carcinogenesis. Mutation Research, v. 202, p. 429 - 446, 1988.

HERMAN, A.; TANSKI, J.M.; TIBBETTS, M.F; ANDERSON, G.M. Synthesis, Characterization, and in Vitro Evaluation of a Potentially Selective Anticancer, MixedMetal [Ruthenium(III)-Platinum(II)] Trinuclear Complex. Inorganic Chemistry., v. 47, p. 274-280, 2008.

HUANG, S.; XIE, K.; BUCANA, C.D.; ULLRICH, S.E.; BAR-ELI, M. Interleukin 10 Suppresses Tumor Growth and Metastasis of Human Melanoma Cells: Potential Inhibition of Angiogenesis. Clínic. Cancer Research., v.2, p. 1969-1979, 1996.

ISHIDA, S.; LEE, J.; THIELE, D.J.; HERSKOWITZ, I. Uptake of the anticancer drug cisplatin mediated by the copper transporter Ctrl in yeast and mammals. Proc. Natl. Acad. Sci. v.99, p.14298 - 14302, 2002.

INSTITUTO NACIONAL DO CANCÊR (INCA). Disponível em: www.inca.gov.br. Acesso em: 16 de julho, 2009. 
JADESKI L.C.; LALA P.K. Nitric oxide synthase inhibition by NG-nitro-L-arginine methyl ester inhibits tumour-induced angiogenesis in mammary tumours. Am. J. Pathol., v.155, p.1381-1390, 1999.

JAMIESON, E. R.; LIPPARD, S. J. Structure, recognition, and processing of cisplatinDNA adducts. Chem. Rev., v. 99, p. 2467-2498, 1999.

JANEWAY, C.J. Imunobiologia: o sistema imunológico na saúde e na doença, 6.ed. Porto Alegre: Artes Médicas Sul, 2006. 824p.

KARPUZOGLU, E.; AHMED, S. A. Estrogen regulation of nitric oxide and inducible nitric oxide synthase (iNOS) in immune cells: Implications for immunity, autoimmune diseases, and apoptosis. Nitric Oxide, v.15, p.177-186, 2006.

KLOSTERGAARD, J.; LEROUX, M.E.; HUNG, M.C. Cellular models of macrophage tumoricidal effector mechanisms in vitro. J. Immunol., v.147, p.2802-8, 1991.

KLOTZ, L.; SCHMIDT, M.; GIESE, T.; SASTRE, M.; KNOLLE, P.; KLOCKGETHER, T.; HENEKA, M.T. Proinflammatory stimulation and pioglitazone treatment regulate peroxisome proliferator-activated receptor gammalevels in peripheral blood mononuclear cells from healthy controls and multiple sclerosis patients. J. Immunol., v.175, p.4948-4955, 2005.

KOMEDA, S.; BOMBARD, S.; PERRIER, S.; REEDIJK, J.; KOZELKA, J. Kinetic study of azole-bridged dinuclear platinum(II) complexes reacting with a hairpinstabilized double-stranded oligonucleotide. J. Inorg. Biochem., v.96, p.357-366, 2003. KUMAR, A.; D'SOUZA, S.S.; TICKOO, S.; SALIMATH, B.P.; SINGH, H.B. Antiangiogenic and proapoptotic activities of allyl isothiocyanate inhibit ascites tumor growth in vivo. Integr. Cancer Ther., v. 8, p.75-88, 2009.

KUNDU, J.K.; SURH, Y. Inflammation: Gearing the journey to cancer. Mutation Res., v. 659, p.15-30, 2008.

KUNINAKA, S.; YANO, T.; YOKOYAMA, H.; FUKUYAMA, Y.; TERAZAKI, Y.; UEHARA, T.; KANEMATSU, T.; ASOH, H.; ICHINOSE1, Y. Direct influences of pro-inflammatory cytokines (il-1_, tnf-_, il-6) on the proliferation and cell-surface antigen expression of cancer cells. Cytokine, v.12, p. 8-11, 2000.

LASKIN, D.L.; LASKIN, J.D. Role of macrophages and inflammatory mediators in chemically induced toxicity. Toxicology., v.160, p.111-18, 2001.

LEHNINGER, A.L.; NELSON, D.L.E.; COX, M.M. Princípios de bioquímica. Porto Alegre: ArtMed, 1995.

LEWIN, B. Genes VII. Porto Alegre: Artmed, 2001.

LIN, X.; OKUDA, T.; HOLZER, A.; HOWELL, S.B. The copper transporter CTR1 regulates cisplatin uptake in Saccharomyces cereviseae. Mol. Pharmacol, v.62, p.1154 $-1159,2002$. 
LOEWENTHAL, H. \& JAHN, G. Ubertragungversuche mit carcinomatoser Mause Ascitesflussigkeit und ihr Verhalten gegen physikalische und Chemische $\begin{array}{llllll}\text { Einwirkungen. } & \text { Ztschr } & \text { F } & \text { Krebsforsch, } & \text { v.12, } & \text { p.37:439, }\end{array}$

MACKANESS, G.B.Cellular resistance to infection. J. Exp. Med., v. 116, p.381-406, 1962.

MADY, E.A. Antitumor and biochemical effects of Echis coloratus Crude venon on Ehrlich ascite carcinoma cells in vivo. J. Venon Anim. Toxins., v.8, p.283-296, 2002.

MAIA, D.C.G; SASSÁ, M. F.; Marisa C. P. ; CARLOS, I. Z . Influence of Th1/Th2 cytokines and nitric oxide in murine systemic infection induced by Sporothrix schenckii. Mycopathologia., v.161, p. 11-19, 2006.

MANJEET, K. R.; GHOSH, B. Quercetin inhibits LPS-induced nitric oxide and tumor necrosis factor- $\alpha$ production in murine macrophages. Int. J. Immunopharmacol., Oxford, v.21, p.435-443, 1999.

MANTOVANI, A.; SICA, A.; SOZZANI, S.; ALLAVENA, P.; ANNUNCIATA, V.; LOCAT, M. The chemokine system in diverse forms of macrophage activation and polarization. Immunology, v.25, p. 677-686, 2004.

MANTOVANI, A. Inflaming metastasis. Nature, v.457, p.36-37, 2009.

MARON, D.M.; AMES, B.N. Revised methods for the Salmonella mutagenicity test. Mutation Research, V.113, p.173-215, 1983.

MATTOS, J.C.P. DE, DANTAS, F.J.S., BEZERRA, R.J.A.C., BERNARDO-FILHO, M., CABRAL-NETO, J.B., LAGE, C., LEITÃO, A.C., CALDEIRA-DE-ARAÚJO, A. Damage induced by stannous chloride in plasmid DNA. Toxicology Letters. V.116. p.159-163, 2000.

MCAULIFFE, C.A.; SHARMA, H.L.; TINKER, N.D. Cancer chemoterapy involving platinum and other platinum group complexes. In: Chemistry of the platinum group metals-recent development. Holanda: Elsevier, 1991. v.11, cap.16, p.546-593.

M'ERIC, J.B.; ROTTEY, S.; OLAUSSEN, K.; SORIA, J.C.; KHAYAT, D.; RIXE, O.; SPANO, J.P. Cyclooxygenase-2 as a target for anticancer drug development. Oncology Hematology. v.59, p.51-64, 2006.

MILLS, K.H.; MCGUIRK P. Antigen-specific regulatory T cells-their induction and role in infection. Semin Immunol., v.16, p.107-117, 2004.

MIZEL, S.B. Interleukin 1 and T cell activation. Immunol. Rev., v.63, p.51-72, 1982.

MORO, A.C.; MAURO, A.E.; ANANIAS, S.R. Clivagem dos ciclopaladados diméricos $[\mathrm{Pd}(\mathrm{dmba})(\mathrm{m}-\mathrm{X})] 2\left(\mathrm{dmba}=\mathrm{N}, \mathrm{N}\right.$-dimetilbenzilamina; $\left.\mathrm{X}=\mathrm{Cl}, \mathrm{N}_{3}, \mathrm{NCO}\right)$ por tiouréia. Eclética Química. v. 29, p. 57-61, 2004. 
MORO, A.C.; MAURO, A.E.; NETTO, A.V.G.; ANANIAS, S.R.; QUILES, M.B.; PAVAN, F.R.; LEITE, C.Q.F.; HORNER, M.; CARLOS, I. Z. . Antitumor and antimycobacterial activities of cyclopalladated complexes:X-ray structure of $[\mathrm{Pd}(\mathrm{C} 2, \mathrm{~N}-$ $\mathrm{dmba})(\mathrm{Br})(\mathrm{tu})](\mathrm{dmba}=\mathrm{N}, \mathrm{N}$-dimethylbenzylamine, $\mathrm{tu}=$ thiourea). European Journal of Medicinal Chemistry. v. 30, p. 1-5, 2009.

MORTELMANS, K.; ZEIGER, E. The Ames Salmonella/Microsom Mutagenicity Assay. Mutation Research, v. 455, p. 29-60, 2000.

MOSSMAN, T. Rapid colorimetric assay for cellular growth and survival: application to proliferation and citotoxicity assays. J.Immunol. Methods., v.65, p.55-63, 1983.

MUELLER H.; FLURY N.; LIU R.; SCHEIDEGGER S.; EPPENBERGER U. Tumour necrosis factor and interferon are selectively cytostatic in vitro for hormone-dependent and hormone-independent human breast cancer cells. Eur. J. Cancer., v.32, p. 23122318, 1996.

NAKAO, S.; KUWANO,T.; TSUTSUMI- MIYAHARA, C.; UEDA, S.; KIMURA, Y.N.; HAMANO, S.; SONODA, K.; SAIJO, Y.; NUKIWA, T.; STRIETER, R.M.; ISHIBASHI, T.; KUWANO, M.; ONO, M. Infiltration of COX2-expressing macrophages is a prerequisite for IL-1binduced neovascularization and tumor growth. $\mathbf{J}$. Clin. Invest., v.115, p.2979-2991, 2005.

NASTALA, C.L.; EDINGTON, H.D.; MCKINNEY, T.G. Recombinant IL-12 administration induces tumor regression in association with IFN-g production. $\mathbf{J}$. Immunol., v. 706, p. 153-1697, 1994.

NATHAN, C..F. Secretory products of macrophages, J. Clin. Invest., v.79, p.319-326, 1987.

NATHAN, C.F. Nitric oxide as a secretory product of mammalian cells. FASEB J., v.6, p.3051-3064, 1992.

NAUGLER, W. E.; SAKURAI, T.; KIM, S.; MAEDA, S.; KIM, K.; ELSHARKAWY, A.M.; KARIN, M. Gender disparity in liver cancer due to sex differences in MyD88dependent IL-6 production. Science, v.317, p.121-124, 2007.

NAUNDORF, S.; SCHRODER, M.; HOFLICH, C.; SUMAN, N.; VOLK, H.D.; GRUTZ, G. IL-10 interferes directly with TCR-induced IFN-gamma but not IL-17 production in memory T cells. Eur. J. Immunol., 2009 (in press).

NAVARRO-RANNINGER, C.; LÓPEZ-SOLERA, I.; GONZÁLEZ, V.M.; PÉREZ, J. M.; ALVAREZ-VALDÉZ, A.; MARTIN, A.; RAITHBY, P. R.; MASAGUER, J. R.; ALONSO, C. Cyclometalated complexes of platinum and palladium with N-(4chlorophenyl)- $\alpha$-benzoylbenzylideneamine. In vitro cytotoxic activity, DNA modification, and interstrand cross-link studies. Inorg. Chem., v.35, p.5181-5187, 1996. 
NICOLINI, A.; CARPI, A.; ROSSI, G. Cytokines in breast cancer. Cytokine \& Growth Factor Rev., v.17, p.325-337, 2006.

O’DWYER, P.J.; STEVENSON, J.P.S.; JOHNSON W.; LIPPERT B. (Ed.), Cisplatin. Chemistry and Biochemistry of a Leading Anticancer Drug, Wiley VCH, Weinheim, 1999, p. 31-69.

OLORIS, S.C.S.; DAGLI, M.L.Z. \& GUERRA, J.L. Effect of bcarotene on the development of the solid Ehrlich tumor in mice. Life Sci., v. 71, p.717-24, 2002.

OPPENHEIM, J. J.; RUSCETTI, F. W.; FALTYNEK, C. R. Cytokines. In: STITES, D. P.; STOBO, J. D.; WELLS, J. V. Basic clin. immunol., 8th. ed. Connecticut: Appleton e Lange, 1994. cap.9, p.105-123.

OSWALD, I.P.; GAZZINELLI, R.T.; SHER, A.; JAMES, S.L. IL-10 synergizes with IL-4 and transforming growth factor- $\beta$ to inhibit macrophage cytotoxic activity. J. Immunol., v.148, p. 3578-3586, 1992.

PAL, S.; CHOUDHURI, T.; CHATTOPADHYAY, S.; BHATTACHARYA, A.; DATTA, G.K.; DAS, T. \& SA, G. Mechanisms of curcumininduced apoptosis of Ehrlich's ascites carcinoma cells. Biochem. Biophys Res. Comm.,v.288, p.658-65, 2001.

PALERMO-NETO, J.; MASSOCO, C.A. \& FAVARE, R.C. Effects of maternal stress on anxiety levels, macrophage activity, and Ehrlich tumor growth. Neurotoxicol. and Terantol., v. 23, p. 497-507, 2001.

PALERMO-NETO, J.; MASSOCO, C.O.; SOUZA, W.R. Effects of physical and psychological stressors on behaviour, macrophage activity, and Ehrlich tumor growth. Brain Behav. Immun., v. 17, p. 43-54, 2003.

PALLADINO, M.A.; BAHJAT, F.R.; THEODORAKIS, E.A.; MOLDAWER, L.L. Anti TNF- $\alpha$ therapies: the next generation. Nat. Rev. Drug Discov., v.2, p.736-746, 2003.

PERRIN, D.D.; AMAREGO, W.L.F.; PERRIN, D. R. Purification of laboratory chemicals. 2.ed. Oxford: Pergamon Press, 1993.

PICK, E.; KEISARI, Y. A simple colorimetric method for the measurement of hydrogen peroxide produced by cell in culture. J. Immunol. Methods., v.38, p.161$170,1980$.

PICK, E.; MIZEL, D. Rapid microassay of measurement of superoxide and hydrogen producties. J. Immunol. Methods., v.46, p.211-226, 1981. 
PINTO, F.C.H. Possíveis mecanismos envolvidos na supressão do tumor de Ehrlich em camundongos com alergia alimentar. Belo Horizonte: Escola de Medicina UFMG, 2003. 91p. Tese de Doutorado (Área - Patologia).

PIVETTA, M. Câncer: esperanças divididas. Pesq. FAPESP, n.99, p.46-53, Maio 2004. QUIROGA, A.G.; PÉREZ, J.M.; LÓPEZ-SOLERA, I.; MASAGUER, J.R.; ROMÁN, A.L.P.; EDWARDS, A.; ALONSO, C.; NAVARRO-RANNINGER, C. Novel Tetranuclear Orthometalated Complexes of $\mathrm{Pd}(\mathrm{II})$ and $\mathrm{Pt}(\mathrm{II})$ Derived from $p$ Isopropylbenzaldehyde Thiosemicarbazone with Cytotoxic Activity in cis-DDP Resistant Tumor Cell Lines. Interaction of These Complexes with DNA. J. Med. Chem., v.41, 1399-1408, 1998b.

QUIROGA, A.G.; PÉRES, J.M.; MONTERO, E.I.; MASAGUER, J.R.; ALONSO, C.; NAVARO-RANNINGER, C. Synthesis and characterization of Pd (II) and Pt (II) complexes of p-isopropylbenzaldehyde $\mathrm{N}$ - protected thiosemicarbazones. Citotoxic activity against ras-transformed cells. J. Inorg. Biochem., v.75, p.293-301, 1999.

RAJESHKUMAR, N.V.; JOY, K.L.; KUTTAN, G.; RAMSEWAK, R.S.; NAIR, M.G. \& KUTTAN, R. Antitumour and anticarcinogenic activity of Phyllanthus amarus extract. J. Ethnopharmacol.,v. 81, p. 17-22, 2002.

RAMASARMA, T. $\mathrm{H}_{2} \mathrm{O}_{2}$ has a role in cellular regulation. Indian J. Biochem. Biophys., v.27, p.269-274, 1990.

REEDJIK, J. Improved understanding in platinium antitumour chemistry. Chem. Commun., p.801-806, 1996.

REMINGTON, R. D., SCHOR, M.A. SOME IMPORTANT DISTRIBUTIONS. IN: JOHNSON, R.A., WICHERN, D.W. (Eds.), Statistics with Applications to the Biological and Health Sciences. Prentice- Hall, Englewood Cliffs, N.J., 1985

RIGBY, R.J.; SIMMONS, J.G.; GREENHALGH, C.J.; ALEXANDER,W.S.; LUND, P.K. Suppressor of cytokine signaling 3 (SOCS3) limits damage-induced crypt hyperproliferation and inflammation-associated tumorigenesis in the colon. Oncogene. v.26, p.4833-4841, 2007.

ROCHA, C.O.; CAIRES, A.C.F.; BINCOLETTO, C. Avaliação da citotoxicidade de complexos organometálicos contendo paládio como metal de transição - paladociclos. XXXIV Congresso Brasileiro de Farmacologia e Terapêutica Experimental, 2003. Salmonella typhimurium (Teste de Ames) como indicador de carcinogenicidade em potencial para mamíferos. In: RIBEIRO, L. R.; SALVADORI, D. M. F.; MARQUES, E. Mutagênese Ambiental. Canoas: Editora da Ulbra, 2003.

RUSHMORE, T.H.; PICKET, C.B. Glutathione-S-transferase, structure, regulation, and therapeutic implication. J. Biol. Chem., v.268, p.11475- 11478, 1993.

SAMBROOK, J., FRITSCH, E.F., MANIATS, T. Molecular Cloning: A Laboratory Manual. Cold Spring Harbor Laboratory, Cold Spring Harbor, NY, 1989. 
SAKAGAMI, T.; VELLA, J.; DIXON, M.F.; ROURKE, J.; RADCLIFF, F.; SUTTON, P.; SHIMOYAMA, T.; BEAGLEY, K.; LEE, A. The endotoxin of Helicobacter pylori is a modulator of host-dependent gastritis. Infect. Immun., v.65, p.3310-3316, 1997.

SCHACHNA, L. The anti-TNF revolution in ankylosing spondylitis. Med. J. Aust., Sydney, v.181, n.10, p.529-530, 2004

SEGURA, J.A., BARBERO, L.G., MÁRQUEZ, J. Ehrlich ascites tumour unbalances splenic cell populations and reduces responsiveness of T cells to Staphylococcus aureus enterotoxin B stimulation. Immunology Letters, v. 74, p. 111- 115, 2000.

SENCHINA, D.S.; DUSTIN, A. M; ASP, J. M.; JOHNSON, J.A.; CUNNICK, J. E.; KAISER, M.;S. KOHUT, M.L. Changes in immunomodulatory properties of Echinacea spp. root infusions and tinctures stored at $4{ }^{\circ} \mathrm{C}$ for four days. Clin. Chim. Acta, v.355, p.67-82, 2005.

SEO, K.Y.; JELINSKY, S.A.; LOECHLER, E.L. Factors that influence the mutagenic patterns of DNA adducts from chemical carcinogens. Mutation Research, v. 463, p. $215-246,2000$.

SERVE, H.; STEINHAUSER, G.; OBERBERG, D.; FLEGEL, W.A.; NORTHOFF, H.; BERDEL, W.E. Studies on the Interaction between Interleukin 6 and Human Malignant Nonhematopoietic Cell Lines. Cancer Research., v. 51, p. 3862-3866, 1991.

SHERMAN, S.E.; LIPPARD, S.J. Structural aspects of platinum anticancer druginteractions with DNA. Chem. Rev., v.87, p.1153-1181, 1987.

SILVA, A.E.; SANTOS, F.G.A.; CASSALI, G.D. Marcadores de proliferação celular na avaliação do crescimento do tumor sólido e ascítico de Ehrlich. Arq. Bras. Med. Vet. Zootec., v.58, p.658-661, 2006.

STITES, D.P.; TERR, A.I.; PARSLOW, T.G. Imunologia médica. 9. ed. Rio de Janeiro: Guanabara Koogan, 2000. 669p.

TAHARA, H.; ZE, H.; STORKUS, W.J. Fibroblasts genetically engineered to secrete interleukin-12 can suppress tumor growth in vivo and induce antitumor immunity to a murine melanoma. Cancer. Res., v9, p.54:182, 1994.

THIEMERMANN, C.; VANE, J. Inhibition of nitric oxide synthesis reduces the hypotension induced by bacterial lipopolysaccharides in the rat in vivo. Eur. J. Pharmacol., v.182, p.591-595, 1990.

THOMASZ, L.; ARAN, M.; PIZARRO, R.A.; IBAÑEZ, J.; PISAREV, M.A.; CONVERSO, D.; JUVENAL, G.J.; KRAWIEC, L. Inhibition of peroxidase and catalase activities and modulation of hydrogen peroxide level by inositol phosphoglycan-like compounds. Horm Metab Res., v.39, p.14 - 19, 2007. 
TORISU, H.; ONO, M.; KIRYU, H.; FURUE, M.; OHMOTO, Y.; NAKAYAMA, J., NISHIOKA, Y.; SONE,S.; UWANO, M. Macrophage infiltration correlates with tumor stage and angiogenesisin human malignant melanoma: possible involvement of TNF alpha and IL-1 alpha, Int. J. Cancer., v. 85, p.182-188, 2000.

TROFIMENKO, S. Cyclopalladation reaction, Inorg. Chem.,v.12, p. 1215-1221, 1973.

VALADARES, M.C.; QUEIROZ, M.L.S. The effect of a titanocene dichloride derivative, Ti IV (C5H5)2 NCS2, on the haematopoietic response of Ehrlich tumourbearing mice. Eur. J. Pharmacol., v.439, p.35-42, 2002.

VALKO, M.; RHODES, C.J.; MONCOLA, J.; IZAKOVIC, M.; MAZURA, M. Free radicals, metals and antioxidants in oxidative stress-induced cancer. Chemico$\begin{array}{lllll}\text { Biological } & \text { Interactions, } & \text { v.160, } & \text { p. } & 1-40,\end{array}$

VERNOOY, J.H.; DENTENER, M.A.; VAN SUYLEN, R.J.; BUURMAN, W.A.; WOUTERS, E.F. Long-term intratracheal lipopolysaccharide exposure in mice results in chronic lung inflammation and persistent pathology. Cell. Mol. Biol., v.26, p.152159, 2002.

WEISBURGER, J.H. Eat to live, not live to eat. Nutrition, v. 16, p. 767-773, 2000.

WORLD HELTH ORGANIZATION (WHO), Disponível em: www.who.int/tdr/diseases/cancer/direction.htm. Acesso em: 16 de julho, 2009.

YONEDA, K.; YAMAMOTO, T.; UETA, E.; OSAKI, T. The inhibitory action of BOFA2, a 5-fluorouracil derivative, on squamous cell carcinoma. Cancer Lett., v. 25, p.1725, 1999.

YOSHINO, M.; HANEDA, M.; NARUSE, M.; MURAKAMI, K. Prooxidant activity of flavonoids: Copper-dependent strand breaks and the formation of 8- hydroxy-2deoxyguanosine in DNA. Molecular Genetics and Metabolism., v. 68, p. 468-472, 1999.

XIE, K. FIDLER, I.J. Therapy of cancer metastasis by activation of the inducible nitric oxide synthase. Cancer Metastasis Rev. v.17, p.55-75, 1998.

ZAHA, A. Biologia molecular básica. Porto Alegre: Mercado Aberto, 1996.

ZEIGER, E. Identification of rodent carcinogens and non-carcinogens using genetic toxicity tests: premises, promises, and performance. Regulatory toxicology and pharmacol., v.28, p.85-95, 2000.

ZHOU, P.; SIEVE, M. C.; BENNETT, J.; KWON-CHUNG, K. J.; TEWARI, R. P.; GAZZINELLI, R. T.; SHER, A.; SEDER, R. A. IL-12 prevents mortality in mice infected with Histoplasma capsulatum through induction of IFN-gamma. J. Immunol., v.155, p.785-795, 1995. 